UNIVERSIDADE DE SÃO PAULO

ESCOLA DE ENGENHARIA DE SÃO CARLOS

DEPARTAMENTO DE HIDRÁULICA E SANEAMENTO

PROGRAMA DE PÓS-GRADUAÇÃO EM HIDRÁULICA E SANEAMENTO

Daniele Vital Vich

\title{
ATIVIDADE METANOGÊNICA E COMUNIDADE MICROBIANA ENVOLVIDAS NA DEGRADAÇÃO DE METILAMINA
}

Dissertação apresentada à Escola de Engenharia de São Carlos da Universidade de São Paulo, como parte dos requisitos para obtenção do Título de Mestre em Hidráulica e Saneamento.

Orientadora: Profa. Dra. Maria Bernadete A. Varesche

São Carlos, SP.

Agosto de 2006 
AUTORIZO A REPRODUÇÃO E DIVULGAÇÃO TOTAL OU PARCIAL DESTE TRABALHO, POR QUALQUER MEIO CONVENCIONAL OU ELETRÔNICO, PARA FINS DE ESTUDO E PESQUISA, DESDE QUE CITADA A FONTE.

Ficha catalográfica preparada pela Seção de Tratamento da Informação do Serviço de Biblioteca - EESC/USP

Vich, Daniele Vital

Atividade metanogênica e comunidade microbiana envolvidas na degradação de metilamina / Daniele Vital Vich; orientador Maria Bernadete A. Varesche. -- São Carlos, 2006.

Dissertação (Mestrado - Programa de Pós-Graduação e Área de Concentração em Hidráulica e Saneamento) -Escola de Engenharia de São Carlos da Universidade de São Paulo.

1. Degradação anaeróbia. 2. Metilamina.

3. Atividade metanogênica específica. 4. PCR/DGGE. I. Título. 


\section{DEDICATÓRIA}

À minha mãe Maria Isabel e ao meu pai José Roberto, pela ajuda em mais um grande passo.

À minha orientadora Dra. Maria Bernadete A. Varesche, por acreditar neste trabalho. 


\section{Agradecimentos}

À Professora Dra. Bernadete A. Varesche pela amizade, acolhimento e orientação.

À Professora Tit. Maria do Carmo Calijuri e ao Professor Assoc. Marcelo Zaiat por acreditarem no meu potencial, pela compreensão, ajuda e contribuição para o meu aperfeiçoamento profissional.

À CNPq pela concessão da bolsa de estudos durante o período de vigência do mestrado.

Às secretárias do Departamento de Hidráulica e Saneamento Sá e Pavi pela constante ajuda nos assuntos burocráticos.

À Beth Moraes, Janja, Eloísa e Glauce pelos bons momentos compartilhados e pela constante ajuda no laboratório.

Aos amigos de disciplinas e LPB (em ordem alfabética): Alexandre, Ana Carolina, Ana Lúcia, Andréa, Arnaldo, Érika, Estela, Géssia, Gláucio, Gunther, Isabel, Joel, Julia, Karina. Kátia, Kelly, Lara, Lorena, Lucas, Luiz Ricardo, Magdalena, Mércia, Sandra, Tininha, Thiago e tantos outros que fizeram do LPB um ambiente gostoso para trabalhar.

À Bruna pela amizade, ajuda e momentos de descontração.

Ao Leonardo pela constante ajuda

À Carolina, Cristina e Juliana, grandes amigas para todas as horas.

À grande amiga Aracely.

Aos amigos da UNESP de Rio Claro, em especial André, Fabrício, Gleiciani, Jordan, Marcinha e Roberta, eternos companheiros de graduação.

Aos meus avós e tios pela importante base familiar, alegrias compartilhadas, carinho e suporte nas horas difíceis.

Ao Matheus pela alegria, pelo apoio e conforto nos momentos de incerteza e por acreditar no nosso futuro.

Ao meu irmão Junior e meus primos Rogério e Camila, melhores amigos.

À minha mãe Maria Isabel e ao meu pai José Roberto pela vida, exemplo e dedicação ao longo de todos esses anos.

A todos que, de alguma maneira, contribuíram para a realização deste trabalho. 
Basta olharmos para uma coisa com atenção para que ela se torne interessante.

Eugênio D'ors 


\section{LISTA DE FIGURAS}

$\begin{array}{ll}\text { Figura 3.1: Árvore filogenética do Domínio Archaea } & 7\end{array}$

Figura 3.2: Vias da metanogênese: hidrogenotrófica (setas azuis), acetoclástica (setas verdes) e metilotrófica (setas vermelhas)

Figura 4.1: Fluxograma experimental

Figura 4.2: Reator anaeróbio em batelada

Figura 4.3: Reatores anaeróbios em batelada

Figura 4.4: Esquema de diluição do NMP

Figura 5.1: Variação temporal da produção de metano no reator anaeróbio controle (1)

Figura 5.2: Variação temporal da produção de metano no reator anaeróbio controle (2)

Figura 5.3: Variação temporal da produção de metano no reator anaeróbio (1) alimentado com $5 \mathrm{mM}$ de metilamina

Figura 5.4: Variação temporal da produção de metano no reator anaeróbio (2) alimentado com $5 \mathrm{mM}$ de metilamina

Figura 5.5: Variação temporal da produção de metano no reator anaeróbio (1) alimentado com $10 \mathrm{mM}$ de metilamina

Figura 5.6: Variação temporal da produção de metano no reator anaeróbio (2) alimentado com $10 \mathrm{mM}$ de metilamina

Figura 5.7: Variação temporal da produção de metano no reator anaeróbio (1) alimentado com 20mM de metilamina

Figura 5.8: Variação temporal da produção de metano no reator anaeróbio (2) alimentado com 20mM de metilamina

Figura 5.9: Variação temporal da produção de metano no reator anaeróbio (1) 37 alimentado com 30mM de metilamina

Figura 5.10: Variação temporal da produção de metano no reator anaeróbio (2) alimentado com 30mM de metilamina

Figura 5.11: Variação temporal da produção de metano no reator anaeróbio (1) alimentado com 50mM de metilamina

Figura 5.12: Variação temporal da produção de metano no reator anaeróbio (2) alimentado com 50mM de metilamina

Figura 5.13: Variação temporal da produção de metano no reator anaeróbio (1) alimentado com $75 \mathrm{mM}$ de metilamina 
Figura 5.14: Variação temporal da produção de metano no reator anaeróbio (2)

Figura 5.15: Variação temporal da produção de metano no reator anaeróbio (1) alimentado com $90 \mathrm{mM}$ de metilamina

Figura 5.16: Variação temporal da produção de metano no reator anaeróbio (2) alimentado com 90mM de metilamina

Figura 5.17: Concentração de sólidos suspensos voláteis para diferentes amostras de reatores anaeróbios alimentados com diferentes concentrações de metilamina (barra de erro de $5 \%)$

Figura 5.18: Ajuste do modelo cinético de Monod

Figura 5.19: Concentrações de $\mathrm{NH}_{4}$ no início e final do experimento e porcentagem de conversão de $\mathrm{N}$ a $\mathrm{NH}_{4}$

Figura 5.20: Número Mais Provável $(\mathrm{NMP} / \mathrm{mL})$ de bactérias anaeróbias totais e arquéias metanogênicas

Figura 5.21: Resultados das análises de DGGE dos fragmentos dos produtos de PCR amplificados com primers do Domínio Bacteria para as amostras: I-inóculo, C-controle (sem metilamina), 5 (5mM de metilamina), 10 (10mM de metilamina), 20 (20mM de metilamina), 30 (30mM de metilamina), 50 (50mM de metilamina), 75 ( $75 \mathrm{mM}$ de metilamina) e 90 (90mM de metilamina)

Figura 5.22: Microscopia de contraste de fase de amostras dos reatores anaeróbios em batelada: a- Methanosaeta sp. (Controle - sem metilamina); b- Filamento (5mM de metilamina); c- Aglomerado de bacilos (5mM de metilamina); d- Bacilos (10mM de metilamina); e- Methanosarcina sp. (10 mM de metilamina); f- Bacilos (20mM de metilamina)

Figura 5.23: Microscopia de contraste de fase e fluorescência de amostras dos reatores anaeróbios em batelada: a- Methanosarcina sp. (30mM de metilamina), bMethanosarcina sp. (fluorescência - 30mMB de metilamina); c- Methanosaeta sp. (50mM de metilamina); d- Bacilos (30mM de metilamina); e- Methanosarcina sp. (50mM de metilamina); f- Filamento (50mM de metilamina)

Figura 5.24: Microscopia de contraste de fase de amostras dos reatores anaeróbios em batelada: a- Methanosaeta sp. (50mM de metilamina), b- Methanosarcina sp. (50mM de metilamina); c- Sarcinas ( $75 \mathrm{mM}$ de metilamina), d- Cocos ( $75 \mathrm{mM}$ de metilamina); e- Coco-bacilos, bacilos e Methanosaeta sp. (90mM de metilamina); f- Filamentos (90mM de metilamina)

Figura 5.25: Resultados das análises de DGGE dos fragmentos dos produtos de PCR amplificados com primers do Domínio Archaea para as amostras: I-inóculo, C-controle (sem metilamina), 5 (5mM de metilamina), 10 (10mM de metilamina), 20 (20mM de metilamina), 30 (30 $\mathrm{mM}$ de metilamina), 50 (50mM de metilamina), 75 ( $75 \mathrm{mM}$ de metilamina) e 90 (90mM de metilamina) 


\section{LISTA DE TABELAS}

Tabela 3.1: Código europeu de avaliação da $\mathrm{LD}_{50}$ de compostos químicos

Tabela 3.2: Avaliação do risco toxicológico de compostos químicos

Tabela 3.3: Código americano de avaliação de riscos á saúde de compostos químicos

Tabela 3.4: Avaliação da inflamabilidade de compostos químicos

Tabela 3.5: Substratos convertidos em metano

Tabela 3.6: Características das famílias de Methanosarcinales

Tabela 3.7: Propriedades fenotípicas das espécies descritas de Methanosarcinales

Tabela 3.7: continuação

Tabela 4.1: Volumes das soluções usadas nos reatores anaeróbios em batelada

Tabela 4.2: Composição do meio basal Zinder

Tabela 4.3: Composição da solução traço de metais

Tabela 4. 4: Composição da solução de vitaminas

Tabela 4.5: Primers usados nas análises de PCR

Tabela 5.1: Período da fase lag, produção máxima de metano e velocidade máxima de formação de metano em cada reator anaeróbio em batelada

Tabela 5.2: Valores de concentração de SVT obtidos nos reatores anaeróbios em batelada

Tabela 5.3: Valores médios de sólidos voláteis totais, atividade metanogênica aparente (AMA), atividade metanogênica específica (AME)

Tabela 5.4: Número Mais Provável (NMP) para bactérias anaeróbias totais e arquéias metanogênicas

Tabela 5.5: Frequência de microrganismos pertencentes ao Domínio Archaea nos reatores alimentados com metilamina

Tabela 5.6: Frequência de microrganismos pertencentes ao Domínio Bacteria nos reatores alimentados com metilamina 


\section{LISTA DE ABREVIATURAS}

AMA - atividade metanogênica aparente

AME - atividade metanogênica específica

DGGE - eletroforese em gel de gradiente desnaturante

DNA - ácido desoxirribonucléico

DNAr - DNA ribossomal

metil-CoM - metil coenzima M

NMP - número mais provável

PCR - reação em cadeia da polimerase

$\mathrm{pH}$ - potencial hidrogeniônico

RNA - ácido ribonucléico

RNAr - RNA ribossomal

rpm - rotação por minuto

SVT - sólidos suspensos voláteis

UASB - reator anaeróbio de fluxo ascendente e manta de lodo 


\section{LISTA DE SÍMBOLOS}

$\mathrm{R}^{2}$ - quadrado do coeficiente de correlação

( ) - marca registrada 


\section{RESUMO}

VICH, D. V. Atividade metanogênica e comunidade microbiana envolvidas na degradação de metilamina. São Carlos, 2006. Dissertação (mestrado) - Escola de Engenharia de São Carlos, Universidade de São Paulo.

A metilamina $\left(\mathrm{CH}_{3} \mathrm{NH}_{2}\right)$ é um composto orgânico usado na produção de inseticidas, herbicidas, fungicidas, surfactantes, combustíveis fósseis, explosivos, produtos farmacêuticos, químicos fotográficos, tintas, tecidos, solventes, borrachas e anti-corrosivos. Estudos sobre tratamento de águas residuárias contendo metilamina são escassos e se restringem aos trabalhos envolvendo pesticidas carbamatados. Visando contribuir com os estudos acerca da degradação anaeróbia da metilamina, esta pesquisa estudou a comunidade microbiana e a atividade metanogênica específica em reatores anaeróbios em batelada, inoculados com lodo granular oriundo de reator UASB usado no tratamento de água residuária de abatedouro de aves, sob diferentes condições nutricionais: controle - sem metilamina, 5 mM, 10 mM, $20 \mathrm{mM}, 30 \mathrm{mM}, 50 \mathrm{mM}, 75$ $\mathrm{mM}$ e $90 \mathrm{mM}$ de metilamina. Os reatores foram incubados sob temperatura de $30^{\circ} \mathrm{C}$ e agitação de 150 rpm. Desses reatores foram obtidas amostras para a determinação da Atividade Metanogênica Específica (AME), Sólidos Suspensos Voláteis (SVT), nitrogênio amoniacal e exames microscópicos. Ao final do experimento, foram realizados exames da biomassa por meio da técnica do Número Mais Provável (NMP) e análise da diversidade microbiana por PCR/DGGE e seqüenciamento. O aumento da AME foi proporcional ao aumento das concentrações de metilamina, com inibição de produção de metano apenas nos reatores alimentados com $90 \mathrm{mM}$ de metilamina. Os reatores alimentados com 50mM e $75 \mathrm{mM}$ de metilamina apresentaram os melhores resultados, com valores médios de AME de 0,0804 $\mathrm{mmol} \mathrm{CH}_{4} / \mathrm{g}$ SVT.h e 0,0825 mmol $\mathrm{CH}_{4} / \mathrm{g}$ SVT.h respectivamente. Nos exames microscópicos foi verificado semelhança de morfologias microbianas em todas as concentrações de metilamina estudadas. Os organismos presentes nos reatores foram Methanosarcina sp., Methanosaeta sp., bacilos, coco-bacilos , filamentos e cocos. Em relação à análise de DGGE, não houve variação significativa nos padrões de bandas, tanto para o Domínio Archaea quanto para o Domínio Bacteria. Com os resultados da técnica de Número Mais Provável (NMP) observou-se a predominância de arquéias metanogênicas dentre as bactérias anaeróbias totais.

Palavras -chave: degradação anaeróbia, metilamina, atividade metanogênica específica, PCR/DGGE. 


\begin{abstract}
VICH, D. V. Methanogenic activity and microbial community involved in the degradation of methylamine. São Carlos, 2006. M.Sc. Dissertation - Escola de Engenharia de São Carlos, Universidade de São Paulo.
\end{abstract}

The methylamine $\left(\mathrm{CH}_{3} \mathrm{NH}_{2}\right)$ is an organic compound used in the production of insecticides, herbicides, fungicides, surfactants, fossil fuels, explosives, pharmaceuticals, photographic chemicals, paints, textiles, dyes, rubber and anticorrosive chemicals. Some studies about the treatment of wastewater containing methylamine are scarce and limited to works involving carbamate pesticides. This research aimed to study the anaerobic degradation of methylamine, the microbial community and the specific methanogenic activity in anaerobic battled reactors. The reactors were inoculated with granular sludge from a UASB reactor treating poultry wastes. Different nutritional conditions were adopted in the operation of the reactors: control (without methylamine), $5 \mathrm{mM}, 10 \mathrm{mM}, 20 \mathrm{mM}, 30 \mathrm{mM}, 50 \mathrm{mM}, 75 \mathrm{mM}$ and $90 \mathrm{mM}$ of methylamine. The reactors were incubated under standard conditions: $30^{\circ} \mathrm{C}$ and $150 \mathrm{rpm}$. Samples had been removed from the reactors to determine the specific methanogenic activity, the concentration of volatile suspended solids and ammoniacal nitrogen and the microscopic analysis. At the end of the experiment, the biomass was studied by the Most Probable Number (MPN) technique and by the microbial diversity analysis with PCR and DGGE techniques. The increase of the specific methanogenic activity was proportional to the increase of methylamine concentration. The methane production was inhibited only in the reactor that was fed with $90 \mathrm{mM}$ of methylamine. The reactors that were fed with $50 \mathrm{mM}$ and $75 \mathrm{mM}$ of methylamine showed the best results, with medium values of specific methanogenic activity equal to $0,0804 \mathrm{mmol} \mathrm{CH}_{4} / \mathrm{g}$ SVT.h and 0,0825 mmol $\mathrm{CH}_{4} / \mathrm{g}$ SVT.h, respectively. The microscopic analysis showed similarity between the microbial morphologies in all of the reactors. The obsreved microorganisms were Methanosarcina sp., Methanosaeta sp., rods, cocci and filaments. The DGGE analysis did not show significant variation in the standard profile of the Archaea and Bacteria domains. The results of the MPN technique revealed the predominance of the methanogenic archaea among the total anaerobic bacteria.

Key Words: anaerobic degradation, methylamine, specific methanogenic activity, PCR/DGGE. 


\section{SUMÁRIO}

LISTA DE FIGURAS i

$\begin{array}{ll}\text { LISTA DE TABELAS } & \text { iii }\end{array}$

LISTA DE ABREVIATURAS iv

LISTA DE SÍMBOLOS V v

RESUMO vi n vi v

ABSTRACT vii

1. INTRODUÇÃO

2. OBJETIVOS 3

$\begin{array}{lc}\text { 2.1. Objetivos específicos } & 3\end{array}$

3. REVISÃO BIBLIOGRÁFICA 4

$\begin{array}{ll}\text { 3.1. Metilamina } & 4\end{array}$

3.2. Domínio Archaea 6

3.3. A Ordem Methanosarcinales 9

3.4. Família Methanosarcinaceae 12

$\begin{array}{lr}\text { 3.4.1. Methanosarcina } & 12\end{array}$

$\begin{array}{lr}\text { 3.4.2. Methanolobus } & 12\end{array}$

$\begin{array}{lr}\text { 3.4.3. Methanococcoides } & 12\end{array}$

$\begin{array}{lr}\text { 3.4.4. Methanohalobium } & 13\end{array}$

$\begin{array}{ll}\text { 3.4.5. Methanohalophilus } & 13\end{array}$

$\begin{array}{lr}\text { 3.4.6. Methanosalsum } & 13\end{array}$

$\begin{array}{ll}\text { 3.5. Família Methanosaetaceae } & 13\end{array}$

$\begin{array}{lr}\text { 3.6. Vias Metanogênicas } & 14\end{array}$

3.7. Técnicas para análise da comunidade microbiana 16

4. MATERIAL E MÉTODOS 
4.1. Montagem e operação dos reatores anaeróbios em batelada 20

4.2. Composição e preparo do meio de cultura e soluções estoque 21

$\begin{array}{lr}\text { 4.2.1. Meio basal Zinder } & 21\end{array}$

4.2.2. Solução traço de metais $\quad 22$

4.2.3. Solução de vitaminas $\quad 22$

4.2.4. Solução de bicarbonato de sódio 23

4.2.5. Solução redutora de sulfeto de sódio 23

4.2.6. Solução estoque de metilamina $\quad 24$

4.3. Manutenção da anaerobiose $\quad 24$

$\begin{array}{ll}\text { 4.4. Limpeza e assepsia } & 24\end{array}$

$\begin{array}{lr}\text { 4.4.1. Limpeza da vidraria } & 24\end{array}$

4.4.2. Esterilização por filtração 24

4.4.3. Esterilização em calor úmido $\quad 25$

4.5. Análises cromatográficas $\quad 25$

4.5.1. Determinação de metano 25

4.5.1.2. Avaliação da atividade metanogênica 25

4.5.1.3. Cálculo da atividade metanogênica específica 26

4.5.2. Determinação de ácidos orgânicos voláteis 27

$\begin{array}{ll}\text { 4.6. Análises físico-químicas } & 27\end{array}$

4.6.1. Determinação de nitrogênio amoniacal 27

4.6.2. Determinação de sólidos voláteis totais $\quad 28$

$\begin{array}{lr}\text { 4.7. Análise da diversidade microbiana } & 28\end{array}$

$\begin{array}{lr}\text { 4.7.1. Exames microscópicos } & 28\end{array}$

4.7.2. Avaliação quantitativa dos grupos microbianos anaeróbios 28

$\begin{array}{lr}\text { 4.7.3. Análise de Biologia Molecular } & 29\end{array}$ 
5. RESULTADOS E DISCUSSÃO

6. CONCLUSÕES

7. PERSPECTIVAS FUTURAS

8. REFERÊNCIAS BIBLIOGRÁFICAS

APÊNDICE 1 - Tempo de experimento, área cromatográfica e valores de metano acumulado no headspace dos reatores anaeróbios em batelada alimentados com metilamina.

APÊNDICE 2 - Determinação da velocidade máxima de produção de metano nos reatores anaeróbios em batelada alimentados com metilamina ANEXO 1 - Curva de Calibração do Metano 


\section{INTRODUÇÃO}

Resíduos tóxicos lançados a cada ano no ambiente podem ser transportados por milhares de quilômetros contaminando águas superficiais, subterrâneas e aqüíferos, usados no abastecimento de cidades, indústrias e na agricultura. Seus efeitos danosos podem ser sentidos durante décadas após sua exposição, aumentando a necessidade de desenvolvimento de novas tecnologias e processos de tratamento desses resíduos.

Entre os resíduos gerados pelas atividades humanas, considerável parte é composta por materiais orgânicos que, não tratados e acumulados desordenadamente, podem levar à poluição da água e do solo, à disseminação de doenças entre a população humana e animal, além de provocar odores desagradáveis.

No início de 1960, carbamatos foram desenvolvidos como alternativa ao DDT e outros pesticidas organoclorados. Os carbamatos constituem $25 \%$ da produção anual de pesticidas e são usados em todo o mundo para o controle de insetos, ácaros e nematóides.

É reconhecido que aplicações freqüentes de carbamatos podem resultar em aumento da concentração ou adaptação de microrganismos capazes de degradá-los via mecanismos como indução enzimática, mutação ou transferência genética, aumentando conseqüentemente a velocidade da biodegradação. A degradação destes pesticidas tem a metanogênese estimulada pela elevada hidrólise de $\mathrm{N}$-metil carbamatos produzindo metilamina, que é usada subseqüentemente por arquéias metanogênicas.

A metilamina $\left(\mathrm{CH}_{3} \mathrm{NH}_{2}\right)$ também é usada para diversas finalidades, dentre as quais se pode destacar: (1) produção de inseticidas, herbicidas, fungicidas, surfactantes, combustíveis fósseis, explosivos, produtos farmacêuticos, químicos fotográficos, tintas, tecidos, solventes, borrachas e anti-corrosivos; (2) inibição da polimerização de hidrocarbonetos durante a destilação; (3) prevenção do enovelamento e coagulação em látex naturais e sintéticos; (4) prevenção da polimerização em removedores de tintas. 
A metilamina é estudada: (1) em sistemas de biofiltros, para neutralização de seu odor e sua retirada do ar; (2) em ambientes estuarinos, para controle do fluxo de $\mathrm{N}$ que ocorre no sedimento e no material particulado suspenso, contribuindo para as florações algais; (3) na área médica, pois desempenha importante papel em distúrbios do sistema nervoso observados durante doenças renais e hepáticas. A via metabólica de degradação da metilamina tende à formação de formaldeído em níveis tóxicos capazes de provocar arteriosclerose.

Estudos sobre tratamento de águas residuárias contendo metilamina são escassos e se restringem aos trabalhos envolvendo pesticidas carbamatados. Mesmo sendo tóxica, ainda não foram desenvolvidas tecnologias de tratamento e remoção da metilamina no ambiente.

Sendo assim, este trabalho tem como caráter inovador a caracterização da comunidade microbiana envolvida na degradação anaeróbia de metilamina e conseqüente produção de metano em reatores em batelada com diferentes concentrações desse composto. Todas essas informações são úteis na compreensão das vias de degradação dos pesticidas carbamatados e no desenvolvimento de tecnologias que visem à recuperação de eventuais áreas contaminadas com metilamina. 


\section{OBJETIVOS}

O objetivo principal desta pesquisa foi avaliar a atividade metanogênica específica e a comunidade microbiana envolvidas na degradação de metilamina em reatores anaeróbios em batelada.

\subsection{Objetivos específicos}

- Quantificar as bactérias anaeróbias e arquéias metanogênicas por meio da técnica do Número Mais Provável (NMP).

- Caracterizar a comunidade microbiana em relação ao Domínio Bacteria e Domínio Archaea de reatores anaeróbios em batelada por meio de técnicas de Biologia Molecular e exames microscópicos. 


\section{REVISÃO BIBLIOGRÁFICA}

\subsection{Metilamina}

A metilamina é um gás à temperatura ambiente, com peso molecular de 31,1, ponto de ebulição de $-6,32^{\circ} \mathrm{C}(760 \mathrm{~mm} \mathrm{Hg})$ e odor semelhante a amônia. Outros sinônimos para o composto são metilamina anidro, monometilamina, aminometano, carbinamina, mercurialina e metanamina (OSHA, 2006).

Em sua forma gasosa, a metilamina irrita severamente o sistema respiratório e os olhos. Sua $\mathrm{LD}_{50}$ (dose letal capaz de matar $50 \%$ da população testada) é de 0,1 a 0,2 g/kg em ratos expostos oralmente à solução aquosa de 40\%. Rápidas exposições em ambientes com 20 a 100 ppm do gás produzem irritações transitórias nos olhos, nariz e garganta. Dermatites e conjuntivites são ocasionalmente observadas em trabalhadores depois de exposição prolongada ao vapor. Experimentos com animais submetidos ao contato de uma gota de solução de metilamina aquosa $5 \%$ mostraram o desenvolvimento de conjuntivite hemorrágica, opacidade superficial na córnea e edemas. Uma gota de solução aquosa $40 \%$ causou necrose quando aplicada à pele de coelhos, e danos à córnea quando em contato com os olhos (OSHA, 2006).

Códigos de segurança, que avaliam compostos químicos, englobam a metilamina em suas classificações quanto à periculosidade. De acordo com as Tabelas 3.1, 3.2, 3.3 e 3.4, a metilamina é considerada corrosiva, nociva, de alto risco à saúde e de inflamabilidade extrema. 
Tabela 3.1. Código europeu de avaliação da $L D_{50}$ de compostos químicos

\begin{tabular}{c|l}
\hline \multicolumn{1}{c}{ Categoria de Risco do Composto } \\
\hline Categoria de Risco & $\begin{array}{l}\text { 1- Extremamente perigoso: a } \mathrm{LD}_{50} \text { para coelhos expostos por } \\
\text { contato direto é menor que } 50 \mathrm{mg} / \mathrm{kg}\end{array}$ \\
$\begin{array}{l}\text { 2- Muito perigoso: a } \mathrm{LD}_{50} \mathrm{para} \text { coelhos expostos por contato } \\
\text { direto é entre } 50 \mathrm{mg} / \mathrm{kg} \text { e } 200 \mathrm{mg} / \mathrm{kg}\end{array}$ \\
$\begin{array}{l}\text { 3- Perigoso: a } \mathbf{L D} \\
\text { é entre } \mathbf{4 0 0} \mathbf{~ m g} / \mathbf{k g} \text { e } 2000 \mathbf{~ m g} / \mathbf{k g}\end{array}$ \\
$\begin{array}{l}\text { 4- Outros: Esse composto tem baixa toxicidade ou nenhuma } \\
\text { informação disponível }\end{array}$ \\
\hline
\end{tabular}

Fonte: OSHA (2006).

Tabela 3.2. Avaliação do risco toxicológico de compostos químicos

\begin{tabular}{c|l|l}
\hline \multicolumn{2}{c}{ Código Europeu de Risco Toxicológico do Composto } \\
\hline Código de Risco & TX = Muito Tóxico & T = Tóxico \\
C, X & CX = Altamente corrosivo & CAN = Carcinogênico \\
& C = Corrosivo & $\mathbf{X}=$ nocivo \\
XI = Irritante & S = Alergênico \\
& V = Baixa toxicidade & n.a. = informações não disponíveis \\
\hline
\end{tabular}

Fonte: OSHA (2006).

Tabela 3.3. Código americano de avaliação de riscos á saúde de compostos químicos

\begin{tabular}{c|l}
\hline \multicolumn{2}{l}{ Avaliação dos Riscos à Saúde - NFPA* } \\
\hline NFPA & $\begin{array}{l}\text { 0 = NENHUM: Danos são causados sob condições não usuais } \\
\text { de exposição ou sob dosagens extremas. } \\
1 \text { = DESPREZÍVEL: Rápida exposição causa danos leves e } \\
\text { reversíveis } \\
2 \text { = MODERADO: Rápida exposição causa danos temporários } \\
\text { e permanentes; pode resultar em danos maiores. } \\
\text { 3= ALTO: Rápida exposição resulta em maiores danos } \\
\text { temporários ou permanentes; perigoso à vida. } \\
4 \text { = EXTREMO: Rápida exposição resulta em danos maiores ou } \\
\text { morte. }\end{array}$ \\
\hline
\end{tabular}

* NFPA = National Fire Protection Association - EUA

Fonte: OSHA (2006). 
Tabela 3.4. Avaliação da inflamabilidade de compostos químicos

\begin{tabular}{c|l}
\hline \multicolumn{2}{c}{ Avaliação da Inflamabilidade - NFPA } \\
\hline Inflamabilidade & 0 = NENHUM: Não é inflamável \\
1 = MÍNIMO: Inflamável em altas temperaturas \\
2 = MODERADO: Inflamável em temperaturas moderadas. \\
3 = SEVERO: Inflamável em todas as temperaturas \\
4 = EXTREMO: Gases ou líquidos muito inflamáveis
\end{tabular}

Fonte: OSHA (2006).

\subsection{Domínio Archaea}

Fração significativa da biosfera terrestre contém ambientes anaeróbios nos quais microrganismos convertem matéria orgânica complexa em metano e dióxido de carbono. Esses microrganismos são encontrados em diversos habitats, tais como rúmen, trato intestinal, digestores de águas residuárias, raízes, sedimentos de rios, lagos e mares. O processo de conversão da matéria orgânica complexa a compostos simples, representados pelas formas mais oxidada $\left(\mathrm{CO}_{2}\right)$ e reduzida $\left(\mathrm{CH}_{4}\right)$ do carbono, requer interação de grupos específicos de organismos anaeróbios (FERRY, 1999).

Segundo FERRY (1999), organismos pertencentes ao Domínio Bacteria convertem a matéria orgânica em hidrogênio, gás carbônico, formiato e acetato, enquanto, alguns organismos do Domínio Archaea convertem todos esses produtos em metano. Ampla variedade de arquéias metanogênicas possui metabolismo anaeróbio obrigatório, enquanto que outras espécies são encontradas em ambientes extremos.

O Domínio Archaea consiste de três divisões: Crenarchaeota, que contém as arquéias redutoras de enxofre hipertermófilas, Euryarchaeota, que compreende ampla diversidade de organismos, incluindo as espécies metanogênicas, as halófilas extremas e uma espécie hipertermófila, e Korarchaeota, uma divisão descrita mais recentemente, que engloba organismos hipertermófilos pouco conhecidos, ainda não cultivados em laboratório. Na figura 3.1 está mostrada a árvore filogenética do Domínio Archaea 


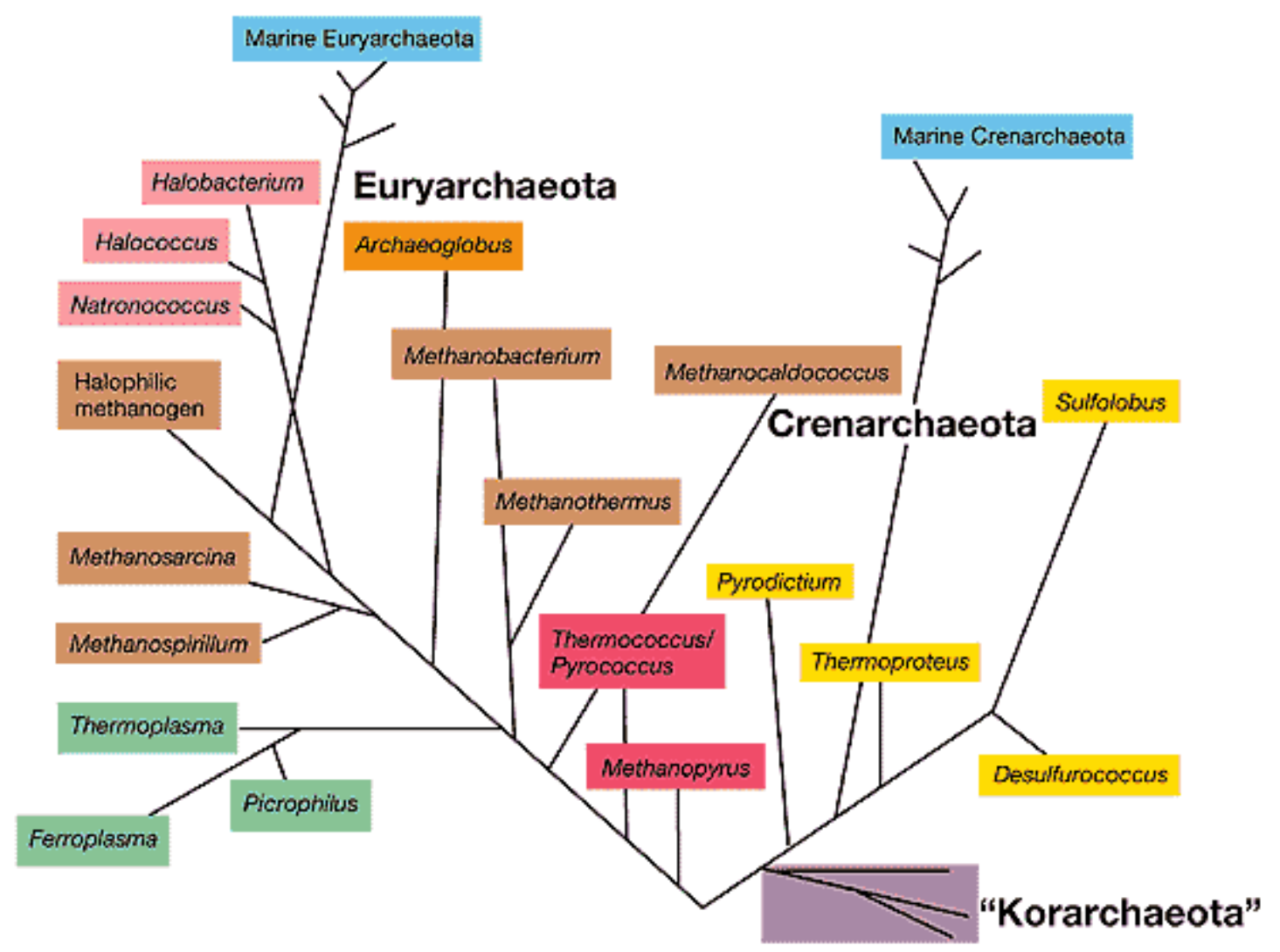

Figura 3.1. Árvore filogenética do Domínio Archaea

Fonte: Adaptado de MADIGAN et al. (2004)

As arquéias produtoras de metano ou metanogênicas são reconhecidas por sua habilidade de obter energia para crescimento através da metanogênese. As arquéias metanogênicas são especializadas na produção de metano, não sendo reconhecida nenhuma espécie capaz de crescer independentemente de sua produção.

A metanogênese requer a biossíntese de seis coenzimas específicas, possui diferentes vias de degradação a metano e complexos enzimáticos específicos que atuam como força motriz no acoplamento de prótons durante a formação de membranas.

As arquéias metanogênicas apresentam ampla variedade morfológica, mas em geral, os organismos correspondem a células procarióticas com diversidade química de paredes celulares. Pelo menos 11 substratos são convertidos em metano por culturas puras de células metanogênicas. Uma classe desses substratos corresponde a substâncias contendo o grupo metil (Tabela 3.5). 
Tabela 3.5. Substratos convertidos em metano

\begin{tabular}{l}
\hline \multicolumn{1}{c}{ Substratos convertidos em metano por arquéias metanogênicas } \\
\hline \multicolumn{1}{c}{ I. Substratos com carbono oxidado } \\
Dióxido de carbono, $\mathrm{CO}_{2}$ (com elétrons derivados do $\mathrm{H}_{2}$, certos álcoois ou piruvato) \\
Formiato, $\mathrm{HCOO}^{-}$ \\
Monóxido de Carbono, $\mathrm{CO}$ \\
\hline II. Substratos metil \\
\hline Metanol, $\mathrm{CH}_{3} \mathrm{OH}$ \\
Metilamina, $\mathrm{CH}_{3} \mathrm{NH}_{3}{ }^{+}$ \\
Dimetilamina, $\left(\mathrm{CH}_{3}\right)_{2} \mathrm{NH}_{2}^{+}$ \\
Trimetilamina, $\left(\mathrm{CH}_{3}\right)_{3} \mathrm{NH}^{+}$ \\
Metilmercaptana, $\mathrm{CH}_{3} \mathrm{SH}$ \\
Dimetilsulfeto, $\left(\mathrm{CH}_{3}\right)_{2} \mathrm{~S}$
\end{tabular}

\section{Substratos acetotróficos}

Acetato, $\mathrm{CH}_{3} \mathrm{COO}^{-}$

Piruvato, $\mathrm{CH}_{3} \mathrm{COCOO}^{-}$

Fonte: MADIGAN et al. (2004)

$\mathrm{Na}$ prática, as arquéias são estudadas e agrupadas de acordo com o seu metabolismo e fisiologia, sendo alocadas em diversos grupos. As espécies do Domínio Archaea mais conhecidas são as metanogênicas, cuja classificação taxonômica data de 1979, realizada por Balch e colaboradores (BALCH et al., 1979). Devido a sua importância para o saneamento ambiental, já estão descritas aproximadamente 66 espécies de metanogênicas, em contraste com aproximadamente 24 espécies de hipertermófilas e 18 de halófilas extremas (SOWERS et al., 1993; ADAMS, 1995; MADIGAN et al., 2004).

Há cinco ordens que divergem filogeneticamente no filo Euryarchaeota e são denominadas “metanogênicas” como descrito a seguir (GARRITY, 2001): Methanomicrobiales, Methanosarcinales, Methanobacteriales, Methanococcales $e$ Methanopyrales. Todas as ordens contêm ampla diversidade de táxons que variam em suas características morfológicas e fisiológicas. Entretanto, todas têm em comum estilo de vida anaeróbio e a habilidade de produzir metano (BAPTESTE et al., 2005).

Embora a Ordem ancestral de ramificação não seja determinada, muitas linhagens de arquéias não metanogênicas aparecem dentro da chave. A filogenia sugere que linhagens representadas por Haloferax, Thermoplasma e Archaeoglobus são derivadas de ancestrais metanogênicos. A redutora de sulfato Archaeoglobus também possui coenzimas não usuais encontradas nos organismos metanogênicos.

Em relação ao substrato usado, a metanogênese pode ser dividida em dois grupos principais. $\mathrm{O}$ primeiro grupo compreende organismos das Ordens Methanobacteriales, Methanococcales, Methanomicrobiales e Methanopyrales, que 
usam apenas hidrogênio e gás carbônico ou formiato como fonte de energia ou substratos. Em contraste, membros da Ordem Methanosarcinales são mais versáteis e usam metanol, metilaminas ou acetato como substratos; muitos deles, também, usam hidrogênio e gás carbônico (DEPPENMEIER et al., 1999). Como conseqüência do reduzido número de substratos e/ou hidrogênio usados pelas arqueias metanogênicas, a degradação anaeróbia da matéria orgânica é mediada por comunidades de diferentes grupos fisiológicos de bactérias anaeróbias.

No filo Euryarchaeota, podemos considerar os gêneros da ordem Methanosarcinales como principais utilizadores de metilaminas como substrato para a metanogênese.

\subsection{A Ordem Methanosarcinales}

Microrganismos pertencentes à Ordem Methanosarcinales catalisam a etapa final da degradação da matéria orgânica em ambientes anaeróbicos, onde a luz e aceptores finais de elétrons diferentes do $\mathrm{CO}_{2}$ são limitados. Representantes desse grupo são cosmopolitas em ambientes anaeróbios, sendo encontrados em água corrente, lama e sedimento marinhos, rúmen de ungulados, lagoas de dejetos animais, lodo de reatores de digestão anaeróbia e fezes de animais. Seqüências genéticas do RNAr 16S que aparentemente pertencem a organismos da Ordem Methanosarcinales foram detectadas em águas presentes nas fissuras de minas de ouro da África do Sul (TAKAI et al., 2001), encanamentos de gás industriais (ZHU et al., 2003) e na cavidade periodontal humana (ROBICHAUZ et al., 2003).

Quanto à morfologia, membros dessa Ordem podem ser cocóides, pseudosarcinas ou bacilos embainhados. A maioria das células possui parede celular protéica, algumas vezes envolta por bainha ou heteropolissacarídeo. Na parede celular não há presença de peptideoglicana ou pseudomureína. As células são estritamente anaeróbias, e obtêm energia com a concomitante produção de metano. Os organismos da Ordem Methanosarcinales são capazes de utilizar vasta gama de substratos orgânicos para a metanogênese, podendo percorrer as vias hidrogenotrófica, metilotrófica e acetoclástica de degradação. Todavia, algumas espécies podem usar apenas uma das vias metabólicas, enquanto outras utilizam as três vias.

A Ordem Methanosarcinales compreende duas Famílias, Methanosarcinaceae e Methanosaetaceae. Suas características distintivas estão listadas na Tabela 3.6, e 
comparações entre as espécies estão expressas na Tabela 3.7. A seguir encontra-se descrito informações sobre a Família Methanosarcinaceae e Methanosaetaceae baseado em GARCIA et al. (2000) e BOONE et al. (2001).

Tabela 3.6. Características das famílias de Methanosarcinales

\begin{tabular}{|c|c|}
\hline FAMÍLIA & CARACTERÍSTICAS \\
\hline Methanosarcinaceae & $\begin{array}{l}\text { - Cocóides ou pseudosarcinas; } \\
\text { - Algumas células podem usar acetato e algumas podem reduzir } \mathrm{CO}_{2} \\
\text { com } \mathrm{H}_{2} \text { como substrato catabólico; } \\
\text { - Nenhuma catabolisa formiato; } \\
\text { - Algumas células são gram-positivas e outras são gram-negativas; } \\
\text { - Células móveis ou sésseis; } \\
\text { - Lipídeos contêm mio-inositol, etanolamina e glicerol como grupos } \\
\text { polares; } \\
\text { - \% C+G = 36-46; } \\
\text { - Habitats incluem sedimentos aquáticos, digestores de lodo anaeróbios e } \\
\text { trato gastrointestinal de animais. }\end{array}$ \\
\hline Methanosaetaceae & $\begin{array}{l}\text { - Bacilos embainhados; } \\
\text { - Acetato é o único substrato catabólico; } \\
\text { - Bainha gram-negativa; sésseis; lipídeos contêm mio-inositol, } \\
\text { etanolamina e galactose como grupos polares; } \\
\text { - \% C+G = 49-54; } \\
\text { - Habitats incluem sedimentos anaeróbios e digestores de lodo } \\
\text { anaeróbios. }\end{array}$ \\
\hline
\end{tabular}

Fonte: WHITMAN et al, (2001)

Tabela 3.7. Propriedades fenotípicas das espécies descritas de Methanosarcinales

\begin{tabular}{|c|c|c|c|c|c|c|c|c|c|c|}
\hline $\begin{array}{l}\mathbf{E} \\
\mathbf{S} \\
\mathbf{P} \\
\mathbf{E} \\
\mathbf{C} \\
\mathbf{I} \\
\mathbf{E}\end{array}$ & $\begin{array}{l}\mathbf{F} \\
\mathbf{O} \\
\mathbf{R} \\
\mathbf{M} \\
\mathbf{A}\end{array}$ & $\begin{array}{l}\text { A } \\
\text { G } \\
\text { R } \\
\text { E } \\
\text { G } \\
\text { A } \\
\text { D } \\
\mathbf{O} \\
\text { S }\end{array}$ & $\begin{array}{l}\text { F } \\
\text { I } \\
\text { L } \\
\text { A } \\
\mathbf{M} \\
\text { E } \\
\mathbf{N} \\
\text { T } \\
\mathbf{O} \\
\text { S }\end{array}$ & $\begin{array}{l}\mathbf{C} \\
\mathbf{I} \\
\mathbf{S} \\
\mathbf{T} \\
\mathbf{O} \\
\mathbf{S}\end{array}$ & $\begin{array}{c}\mathbf{T} \\
\mathbf{A} \\
\mathbf{M} \\
\mathbf{A} \\
\mathbf{N} \\
\mathbf{H} \\
\mathbf{O} \\
\mathbf{( \mu m )}\end{array}$ & $\begin{array}{l}\text { M } \\
\text { Ó } \\
\mathbf{V} \\
\mathbf{E} \\
\mathbf{I} \\
\mathbf{S}\end{array}$ & $\begin{array}{c}\mathrm{C} \\
+ \\
\mathrm{G} \\
(\% \mathrm{~mol})\end{array}$ & $\begin{array}{l}\mathbf{G} \\
\mathbf{R} \\
\mathbf{A} \\
\mathbf{M}\end{array}$ & $\begin{array}{l}\mathbf{V} \\
\mathbf{A} \\
\mathbf{C} \\
\mathbf{U} \\
\mathbf{O} \\
\mathbf{L} \\
\mathbf{O} \\
\mathbf{S}\end{array}$ & $\begin{array}{c}\mathbf{P} \\
\mathbf{L} \\
\mathbf{A} \\
\mathbf{S} \\
\mathbf{M} \\
\mathbf{I} \\
\mathbf{D} \\
\mathbf{E} \\
\mathbf{O}\end{array}$ \\
\hline $\begin{array}{c}\text { Methanosarcina } \\
\text { barkeri }\end{array}$ & Cocos & + & - & - & $1,5-2,0$ & - & $39-44$ & + & + & nd \\
\hline $\begin{array}{c}\text { Methanosarcina } \\
\text { acetivorans }\end{array}$ & Cocos & + & - & + & $1,7-2,1$ & - & 41 & - & - & nd \\
\hline $\begin{array}{c}\text { Methanosarcina } \\
\text { mazeii }\end{array}$ & Cocos & + & - & + & $1,0-3,0$ & - & 42 & + & - & nd \\
\hline $\begin{array}{c}\text { Methanosarcina } \\
\text { siciliae }\end{array}$ & Cocos & + & - & - & nd & nd & $41-43$ & - & - & nd \\
\hline $\begin{array}{c}\text { Methanosarcina } \\
\text { thermophila }\end{array}$ & Cocos & + & - & - & 100 & - & 42 & + & - & nd \\
\hline $\begin{array}{c}\text { Methanosarcina } \\
\text { vacuolata }\end{array}$ & Cocos & + & - & - & $0,5-2,0$ & - & 36 & + & + & nd \\
\hline $\begin{array}{c}\text { Methanosarcina } \\
\text { baltica }\end{array}$ & $\begin{array}{c}\text { Cocos } \\
\text { Irregulares }\end{array}$ & + & - & nd & $1,5-3,0$ & nd & nd & nd & nd & nd \\
\hline
\end{tabular}


Tabela 3.7. continuação

\begin{tabular}{|c|c|c|c|c|c|c|c|c|c|c|}
\hline $\begin{array}{l}\mathbf{E} \\
\mathbf{S} \\
\mathbf{P} \\
\mathbf{E} \\
\mathbf{C} \\
\mathbf{I} \\
\mathbf{E}\end{array}$ & $\begin{array}{l}\mathbf{F} \\
\mathbf{O} \\
\mathbf{R} \\
\mathbf{M} \\
\mathbf{A}\end{array}$ & $\begin{array}{l}\mathbf{A} \\
\mathbf{G} \\
\mathbf{R} \\
\mathbf{E} \\
\mathbf{G} \\
\mathbf{A} \\
\mathbf{D} \\
\mathbf{O} \\
\mathbf{S} \\
\end{array}$ & $\begin{array}{l}\mathbf{F} \\
\mathbf{I} \\
\mathbf{L} \\
\mathbf{A} \\
\mathbf{M} \\
\mathbf{E} \\
\mathbf{N} \\
\mathbf{T} \\
\mathbf{O} \\
\mathbf{S} \\
\end{array}$ & $\begin{array}{l}\mathbf{C} \\
\mathbf{I} \\
\mathbf{S} \\
\mathbf{T} \\
\mathbf{O} \\
\mathbf{S}\end{array}$ & $\begin{array}{c}\mathbf{T} \\
\mathbf{A} \\
\mathbf{M} \\
\mathbf{A} \\
\mathbf{N} \\
\mathbf{H} \\
\mathbf{O} \\
\mathbf{( \mu \mathbf { m } )}\end{array}$ & $\begin{array}{l}\mathbf{M} \\
\text { Ó } \\
\mathbf{V} \\
\mathbf{E} \\
\mathbf{I} \\
\mathbf{S}\end{array}$ & $\begin{array}{c}\text { C } \\
+ \\
\text { G } \\
(\% \mathrm{~mol})\end{array}$ & $\begin{array}{l}\mathbf{G} \\
\mathbf{R} \\
\mathbf{A} \\
\mathbf{M}\end{array}$ & $\begin{array}{l}\mathbf{V} \\
\mathbf{A} \\
\mathbf{C} \\
\mathbf{U} \\
\mathbf{O} \\
\mathbf{L} \\
\mathbf{O} \\
\mathbf{S}\end{array}$ & $\begin{array}{c}\mathbf{P} \\
\mathbf{L} \\
\mathbf{A} \\
\mathbf{S} \\
\mathbf{M} \\
\mathbf{I} \\
\mathbf{D} \\
\mathbf{E} \\
\mathbf{O}\end{array}$ \\
\hline $\begin{array}{c}\text { Methanosarcina } \\
\text { lacustris }\end{array}$ & Cocos & + & - & nd & $1,5-3,5$ & - & 43,4 & + & nd & nd \\
\hline $\begin{array}{c}\text { Methanosarcina } \\
\text { semesiae }\end{array}$ & $\begin{array}{c}\text { Cocos } \\
\text { Irregulares }\end{array}$ & - & - & nd & $0,8-2,1$ & - & $\mathrm{Nd}$ & + & nd & nd \\
\hline $\begin{array}{l}\text { Methanolobus } \\
\text { tindarius }\end{array}$ & Cocos & + & - & nd & $0,8-1,25$ & & 45,9 & - & nd & - \\
\hline $\begin{array}{l}\text { Methanolobus } \\
\text { bombayensis }\end{array}$ & $\begin{array}{l}\text { Cocos } \\
\text { Irregulares }\end{array}$ & - & - & nd & $1,0-1,5$ & - & 39 & - & nd & nd \\
\hline $\begin{array}{l}\text { Methanolobus } \\
\text { oregonensis }\end{array}$ & $\begin{array}{c}\text { Cocos } \\
\text { Irregulares }\end{array}$ & + & - & nd & $1,0-1,5$ & - & 40,9 & - & nd & nd \\
\hline $\begin{array}{l}\text { Methanolobus } \\
\text { taylorii }\end{array}$ & Cocos & + & - & nd & $0,5-1,0$ & - & 41 & - & nd & - \\
\hline $\begin{array}{l}\text { Methanolobus } \\
\text { vulcani }\end{array}$ & $\begin{array}{l}\text { Cocos } \\
\text { Irregulares }\end{array}$ & + & - & nd & $0,8-1,25$ & - & 39 & - & nd & nd \\
\hline $\begin{array}{c}\text { Methanococcoides } \\
\text { methylutens }\end{array}$ & $\begin{array}{c}\text { Cocos } \\
\text { Irregulares }\end{array}$ & - & - & nd & $0,8-1,8$ & - & 42 & - & nd & nd \\
\hline $\begin{array}{c}\text { Methanococcoides } \\
\text { burtonii }\end{array}$ & $\begin{array}{c}\text { Cocos } \\
\text { Irregulares }\end{array}$ & + & - & nd & $0,8-1,8$ & & 39,6 & $\mathrm{~V}$ & nd & nd \\
\hline $\begin{array}{c}\text { Methanohalobium } \\
\text { evetigatum }\end{array}$ & $\begin{array}{c}\text { Esferas } \\
\text { Lisas, } \\
\text { Poligonais e } \\
\text { Irregulares }\end{array}$ & + & - & nd & $\begin{array}{l}0,2-2(\mathrm{~S}) \\
5-10(\mathrm{~A})\end{array}$ & - & 37 & nd & nd & nd \\
\hline $\begin{array}{l}\text { Methanohalophyllu } \\
\text { s mahii }\end{array}$ & $\begin{array}{c}\text { Cocos } \\
\text { Irregulares }\end{array}$ & + & - & nd & $0,8-1,8$ & - & 41 & - & nd & nd \\
\hline $\begin{array}{l}\text { Methanohalophyllu } \\
\text { s halophilus }\end{array}$ & $\begin{array}{c}\text { Cocos } \\
\text { Irregulares }\end{array}$ & + & - & + & $0,5-2,0$ & - & 39 & - & nd & nd \\
\hline $\begin{array}{l}\text { Methanohalophyllu } \\
\text { s portucalensis }\end{array}$ & $\begin{array}{l}\text { Cocos } \\
\text { Irregulares }\end{array}$ & + & - & nd & $0,6-2,0$ & - & 41 & - & nd & nd \\
\hline $\begin{array}{l}\text { Methanosalsum } \\
\text { zhilinae }\end{array}$ & $\begin{array}{c}\text { Cocos } \\
\text { Irregulares }\end{array}$ & + & - & nd & $0,75-1,5$ & & $38-39$ & - & nd & nd \\
\hline $\begin{array}{l}\text { Methanosaeta } \\
\text { concilii }\end{array}$ & $\begin{array}{l}\text { Bacilos } \\
\text { Retos }\end{array}$ & - & + & nd & $\begin{array}{c}0,8-1,3 \\
(\mathrm{~L}) \\
2,0-7,0 \\
(\mathrm{C})\end{array}$ & - & $49 \pm 1,2$ & - & - & nd \\
\hline $\begin{array}{l}\text { Methanosaeta } \\
\text { thermophila }\end{array}$ & $\begin{array}{l}\text { Bacilos } \\
\text { Retos }\end{array}$ & - & + & nd & $\begin{array}{c}0,8-1,3 \\
(\mathrm{~L}) \\
2,0-7,0 \\
(\mathrm{C}) \\
\end{array}$ & - & $52-54$ & - & + & nd \\
\hline
\end{tabular}

Abreviações: nd (não determinado), v (variável), S (sozinho), A (agregado), L (largura), C (comprimento), $\mathrm{C}+\mathrm{G}$ (citosina + guanina)

Fonte: WHITMAN et al, (2001) 


\subsection{Família Methanosarcinaceae}

Methanosarcinaceae inclui seis gêneros de organismos com células cocóides ou pseudosarcinais. A maioria das células possui parede celular protéica. Outras células são circundadas por heteropolissacarídeo ácido. Nenhuma célula contém peptideoglicana ou pseudomureína. Os lipídeos contém mio-inositol, etanolamina e glicerol como grupos polares. Todos os gêneros podem obter energia pela transformação de compostos metilados. $\mathrm{O}$ uso de acetato e a redução de $\mathrm{CO}_{2} \mathrm{com} \mathrm{H}_{2}$ são observados, porém nenhum gênero cataboliza formiato.

\subsubsection{Methanosarcina}

O gênero Methanosarcina compreende nove espécies: Methanosarcina barkeri, Methanosarcina acetivorans, Methanosarcina siciliae, Methanosarcina thermophila, Methanosarcina mazeii, Methanosarcina vacuolata, Methanosarcina baltica, Methanosarcina lacustris e Methanosarcina semesiae. Todas as espécies são sésseis e capazes de catabolisar acetato, metanol, metilaminas e CO. Algumas espécies são capazes de obter energia pela redução do $\mathrm{CO}_{2} \mathrm{com} \mathrm{H}_{2}$.

\subsubsection{Methanolobus}

O gênero Methanolobus é representado por cinco espécies de morfologia cocoidal, Methanolobus tindarus, Methanolobus bombayensis, Methanolobus oregonensis, Methanolobus taylorii e Methanolobus vulcani. Todas as células são envoltas por membrana simples e uma camada protéica. As células podem crescer em metanol, metilaminas e algumas vezes em metilsulfitos. Nenhuma espécie cresce em $\mathrm{H}_{2} / \mathrm{CO}_{2}$, formiato, acetato ou álccois diferentes do metanol.

\subsubsection{Methanococcoides}

O gênero Methanococcoides compreende duas espécies, Methanococcoides methylutens e Methanococcoides burtonii. As células são cocos irregulares, e a parede celular consiste de uma parede celular fina de espessura aproximada de $10 \mathrm{~nm}$. As 
células usam metilaminas e metanol para o crescimento, mas não catabolisam acetato, $\mathrm{H}_{2} / \mathrm{CO}_{2}$, dimetilsulfetos ou formiato.

\subsubsection{Methanohalobium}

O gênero Methanohalobium contém uma única espécie, Methanohalobuim evestigatum. Esta espécie é halófila extrema e termófila moderada. Metilaminas são usadas como substrato para o crescimento. Não são usados acetato, formiato e $\mathrm{H}_{2} / \mathrm{CO}_{2}$. Metanol é catalisado apenas em concentrações inferiores a 20mM (ZHILINA \& ZAVARZIN, 1987, apud BOONE et al., 1993).

\subsubsection{Methanohalophilus}

O gênero compreende três espécies, Methanohalophilus mahii, Methanohalophilus halophillus e Methanohalophilus portucalensis. Células crescem com metilaminas e metanol. Em concentrações maiores que 40mM, o metanol é tóxico às células. Não crescem em álcoois secundários, $\mathrm{H}_{2} / \mathrm{CO}_{2}$ e formiato.

\subsubsection{Methanosalsum}

Methanosalsum zhilinae é a única espécie deste gênero. Cresce em metilaminas, metanol e dimetilsulfetos. Não cresce em acetato, formiato e $\mathrm{H}_{2} / \mathrm{CO}_{2}$. (MATHRANI et al., 1988, apud BOONE et al, 2001²).

\subsection{Família Methanosaetaceae}

Esta família inclui um gênero, Methanosaeta. E todas as células utilizam o acetato como única fonte de carbono.

${ }^{1}$ ZHILINA, T. N. \& ZAVARZIN, G. A. (1987) Methanohalobium evestigatus, gen. nov. sp. nov., the extremely halophilic methanogenic archaebacterium. Dokl Akad Nauk SSSR 293: 464-468

2 MATHRANI, I. M.; BOONE, D. R.; MAH, R. A.; FOX, G. E. \& LAU, P. P. (1988) Methanohalophilus zhilinae, sp. nov., an alkaliphilic, halophilic, methylotrophic methanogen. International Journal of Systematic Bacteriology 38: 139-142 
O gênero Methanosaeta é representado por duas espécies, Methanosaeta concilii e Methanosaeta thermophila, que metabolizam o acetato em metano e $\mathrm{CO}_{2}$. Originalmente, estes organismos foram classificados como pertencentes ao gênero Methanothrix. Como a cultura que validou a espécie não era pura, a mesma foi considerada ilegítima. Cultura axênica de bacilos embainhados, acetoclásticos, mesofílicos e metanogênicos foi descrita por Patel (PATEL, 1984; PATEL, 1985) como Methanothrix concilli e posteriormente transferida para o novo gênero Methanosaeta.

\subsection{Vias Metanogênicas}

Existem três diferentes vias de produção do metano, que variam quanto ao composto de carbono usado como substrato e quanto à fonte do potencial redutor. A via hidrogenotrófica é a mais difundida, sendo encontrada em todas as ordens de organismos. Essa via envolve a redução do $\mathrm{CO}_{2}, \mathrm{com} \mathrm{H}_{2}$ como doador de elétrons, e é composta por sete passos centrais (REEVE et al., 1997). Formiato também pode ser convertido a metano por essa via, atuando como fonte de $\mathrm{CO}_{2}$ e potencial redutor. Duas outras vias são encontradas na ordem Methanosarcinales: via acetoclástica e via metilotrófica.

$\mathrm{Na}$ via acetoclástica, o acetato é dividido em um grupo metil e CO, subseqüentemente oxidado para prover elétrons (MEUER et al., 2002). O grupo metil da degradação do acetato é ligado à metanopterina (ou sarcinapterina, para Methanosarcina) antes de ser reduzido a metano em duas reações enzimáticas, homólogas às que ocorrem nos últimos dois passos da via hidrogenotrófica.

A via metilotrófica, também presente no gênero Methanosphaera, de Methanobacteriales (VAN DE WIJNGAARD et al., 2002), tem diversas variantes possíveis. A via mais estudada é quando compostos com um carbono, ou seja, compostos C-1, como as metilaminas e o metanol, podem ser usados tanto como doadores quanto como aceptores de elétrons. Uma molécula dos compostos C-1 é oxidada (fazendo a via hidrogenotrófica na direção reversa, de metil-CoM a $\mathrm{CO}_{2}$ ) provendo elétrons para a redução de três moléculas adicionais a metano. Entretanto, na presença de metanol e $\mathrm{H}_{2} / \mathrm{CO}_{2}$, algumas Methanosarcinales podem reduzir este composto C-1 usando apenas o último passo da via metanogênica hidrogenotrófica (metil-CoM a $\mathrm{CH}_{4}$ ), tirando elétrons de $\mathrm{H}_{2}$ (Figura 3.1). 
O gênero Methanosphaera apresenta variação da via metilotrófica. Esta Methanobacteriales não reduz $\mathrm{CO}_{2}$ para produção de metano. As células requerem metanol e $\mathrm{H}_{2}$ para crescer, produzindo metano em processo ainda não estudado completamente, mas semelhante à metanogênese hidrogenotrófica em seu último passo (SCHWÖRER \& THAUER, 1991).

Devido à metanogênese ser encontrada somente na ramificação euriarqueal do Domínio Archaea, ela provavelmente originou-se nesse filo. A produção biológica do metano requer pelo menos 25 genes (em adição a mais de 20 proteínas bioquimicamente caracterizadas envolvidas na síntese de coenzimas). Genes codificando diferentes subunidades de uma enzima tendem a ficar aglomerados no genoma, mas estes aglomerados e genes codificados por monômeros ou homopolímeros são dispersos pelo genoma (REEVE et al., 1997). Algumas Methanosarcinales possuem cerca de 250 genes envolvidos em diferentes aspectos da metanogênese (GALAGAN et al., 2002). O número de genes envolvidos, assim como seu arranjo genômico disperso, faz crer que a metanogênese tenha sido adquirida por transferência genética lateral. Entretanto, porções das vias envolvidas nesse processo, com genes isolados, podem ter sido adquiridas por grandes distâncias filogenéticas. Por exemplo, enzimas homólogas às que catalisam os três primeiros passos da redução metanogênica do $\mathrm{CO}_{2}$ são usadas para a oxidação do formaldeído em proteobactérias metilotróficas e planctomicetes. É extremamente improvável que essas enzimas estivessem presentes no ancestral comum de Archaea e Bacteria e se perderam nas linhagens procarióticas. A transferência entre domínios é uma possibilidade muito mais parcimoniosa (CHISTOSERDOVA et al., 2004).

As vias metanogênicas estão esquematizadas na Figura 3.1. Para a síntese de cofatores, a metanopterina hidrogenase $(m p t H)$ desempenha papel importante na biossíntese de tetrahidrofolato, e a metanopterina nitrogenase ( $m p t N)$ está envolvida na biossíntese de metanopterina. Tetrahidrofolato e metanopterina são dois transportadores intermediários de C-1 na metanogênese. A biossíntese da coenzima F420 se apóia nas cof enzimas (cofC, cofD, cofE, cofG e cofH). As aks enzimas ( $a k s A, a k s D$, aksE e aksF) participam nos dois passos de elongação oxiácida da biossíntese da coenzima B9, a qual se associa à coenzima $M$ na etapa final da metanogênese. Esta última coenzima é o menor cofator orgânico conhecido, mas é um transportador de grupo metil essencial para a metanogênese; a coenzima $\mathrm{M}$ é produzida pelas $\operatorname{com}$ enzimas ( $\operatorname{com} A, \operatorname{comB}$, comC, comD e comE). 
Apesar das vias se iniciarem de maneiras diferentes, todas acabam no mesmo passo, a reação da metil-coenzima $\mathrm{M}\left(\mathrm{CH}_{3}-\mathrm{S}-\mathrm{CoM}\right)$ com uma coenzima secundária, denominada coenzima B (CoB-SH), para formação do metano

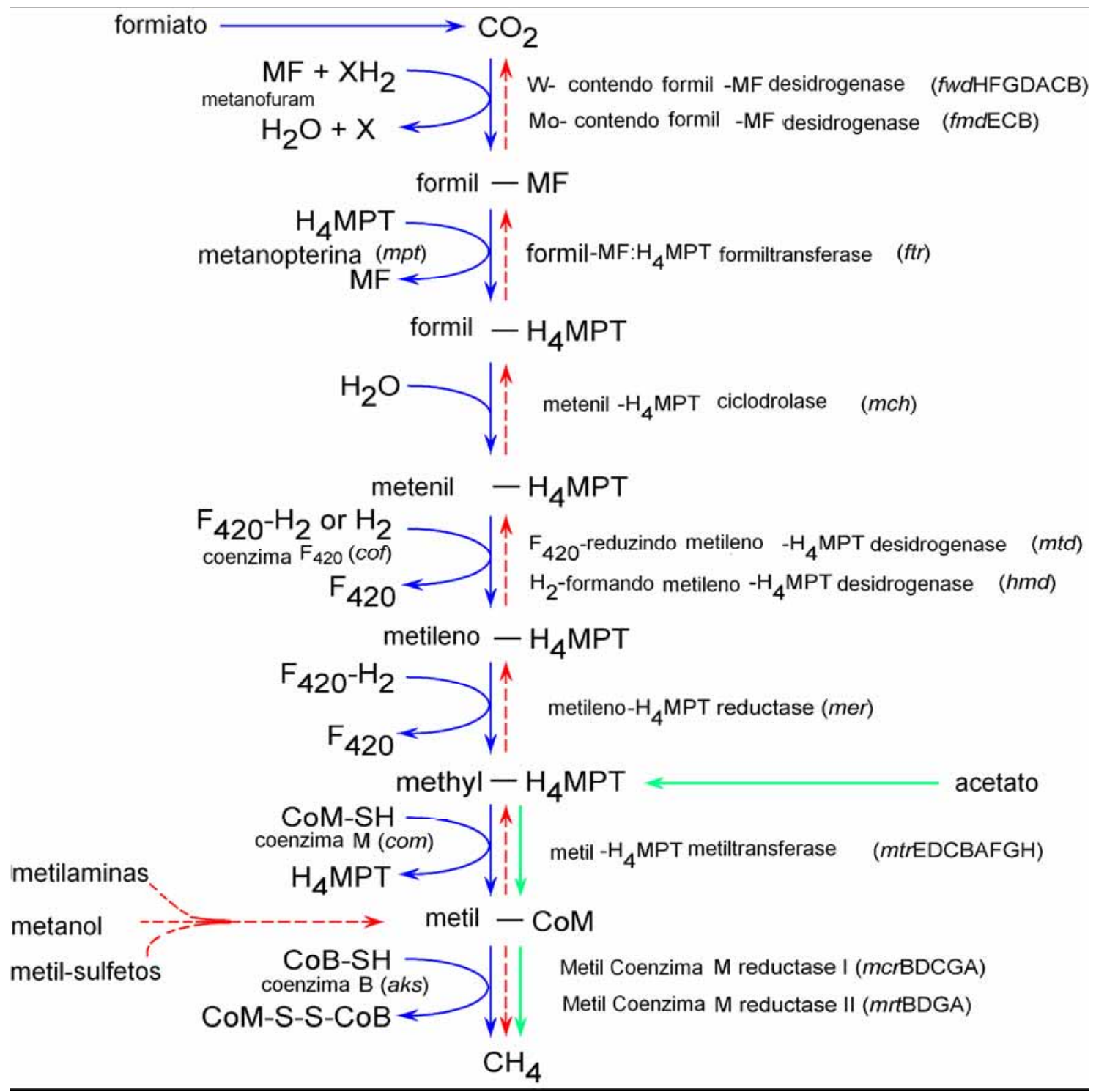

Figura 3.2. Vias da metanogênese: hidrogenotrófica (setas azuis), acetoclástica (setas verdes) e metilotrófica (setas vermelhas).

Fonte: Adaptado de GRAHAM \& WHITE (2002)

\subsection{Técnicas para análise da comunidade microbiana}

As perspectivas para aplicação das técnicas de Biologia Molecular são as descritas a seguir: (a) com o seqüenciamento do DNAr e RNAr os microbiologistas terão a possibilidade de identificar, isolar e caracterizar novos organismos, com respeito a estudos de filogenia e fisiologia; (b) poderá auxiliar no estudo de bactérias não 
cultiváveis; (c) os microrganismos poderão ser estudados em seus nichos, possibilitando correlações entre a composição da comunidade, a relação espacial de membros diferentes e o funcionamento das populações. Essas informações serão importantes para o entendimento das relações simbióticas e, também, para o entendimento da maioria dos ciclos biogeoquímicos (SAKAMOTO, 2001).

A técnica da reação em cadeia da polimerase (PCR) leva à amplificação de um bilhão de vezes um segmento de DNA. Uma molécula do DNA pode ser amplificada a quantidades que permitem a caracterização e manipulação. Esta técnica está sendo usada para detectar patógenos e doenças genéticas, para determinar a fonte de um cabelo deixado na cena de um crime e recuperar genes de fósseis (BERG et al., 2004). Sua importância nos estudos microbiológicos está no fato dessa técnica permitir a amplificação de genes específicos a partir de bactérias isoladas ou de bactérias não cultivadas, para seqüenciamento e avaliação filogenética (WARD et al., 1990).

Técnicas de impressão digital providenciam padrão ou perfil da diversidade genética na comunidade microbiana. A técnica de eletroforese em gel com gradiente desnaturante (DGGE) tem sido introduzida no estudo da ecologia microbiana (MUYZER \& SMALA, 1998).

O DGGE tem as vantagens de ser confiável, reprodutível, rápido e de custo relativamente baixo. Essa técnica permite a análise de várias amostras ao mesmo tempo, o que facilita os estudos de comparação entre comunidades distintas ou relacionadas e de monitoramento de mudanças espaciais e temporais em populações microbianas ao longo de sucessões ecológicas, mudanças ambientais ou processos biotecnológicos. As limitações da técnica, por outro lado, estão ligadas principalmente à eficiência na extração de DNA, aos problemas intrínsecos das técnicas de PCR e à necessidade do manuseio cuidadoso das amostras para evitar alterações na comunidade microbiana. Além disso, um dos problemas do DGGE é o baixo poder de detecção; ou seja, estimase que apenas 1 a $2 \%$ das espécies dominantes possam ser detectadas pela técnica, além da sobreposição de bandas, decorrente de características de mobilidade similares de alguns fragmentos, ou ainda, a presença, em uma única espécie, de várias cópias do gene de DNAr 16S com pequenas diferenças na composição de bases, fazendo com que várias bandas sejam geradas.

Apesar das limitações da técnica de DGGE, ampla variedade de aplicações é possível; entre elas, visando inferir a afiliação filogenética de membros das comunidades, testar a pureza de linhagens bacterianas, monitorar o isolamento de 
bactérias a partir de amostras ambientais, ou estudar a dinâmica de populações específicas frente a variações nos parâmetros ambientais ou condições de operação de um sistema.

O seqüenciamento do DNAr 16S tem oferecido detalhes sobre a composição da estrutura das comunidades microbianas anaeróbias, apontando inclusive a existência e atuação de vários organismos que ainda não estavam descritos em literatura.

A produção do conhecimento através do cruzamento de informações obtidas com as técnicas moleculares e os processos funcionais em reatores é fato muito recente. FERNANDES et al (1999) reportaram que existe uma dinâmica populacional distinta de bactérias e arquéias em reator com 605 dias de operação, mas que parece funcionalmente estável. Assim sendo, os autores constataram que a estabilidade funcional do reator avaliada através das variáveis químicas não se refletia na estabilidade da estrutura microbiana. Essa variação na diversidade estrutural microbiana pode ser mais importante para a estabilidade do reator do que anteriormente se previa.

WALKER (1995) sugeriu que a flexibilidade metabólica do reator esta diretamente relacionada com a diversidade e a estrutura da comunidade microbiana. A flexibilidade metabólica é um recurso que ocorre no reator para evitar flutuações nas concentrações e composições da água residuária afluente. BERLOW et al (1999) evidenciaram que seus resultados apontaram para o mesmo caminho. Em reatores anaeróbios estritos as arquéias dominam os processos biológicos, mas é na diversidade dos microrganismos em menor densidade, aparentemente sem importância funcional, que se encontra a flexibilidade metabólica que previne potenciais perturbações ao sistema. Portanto, a caracterização e o acompanhamento da diversidade microbiana nos reatores anaeróbios não apenas favorece a produção de conhecimento que possa vir a sugerir sobre novas vias metabólicas, mas também é crucial para avaliar a funcionalidade e estabilidade potencial dos reatores contra perturbações (HUANG, et al., 2002). 


\section{MATERIAL E MÉTODOS}

Lodo granular oriundo de reator UASB usado no tratamento de água residuária de abatedouro de aves (Avícola Dakar, Tietê) foi inoculado em reatores em batelada contendo meio Zinder, solução de bicarbonato de sódio 10\%, vitaminas, solução redutora de sulfeto 5\% e solução de metilamina em diferentes concentrações. Amostras dos reatores foram submetidas a diferentes análises. Na Figura 4.1 estão representados esquematicamente todos os passos do experimento. Cada etapa apresentada no esquema será posteriormente descrita em detalhes.

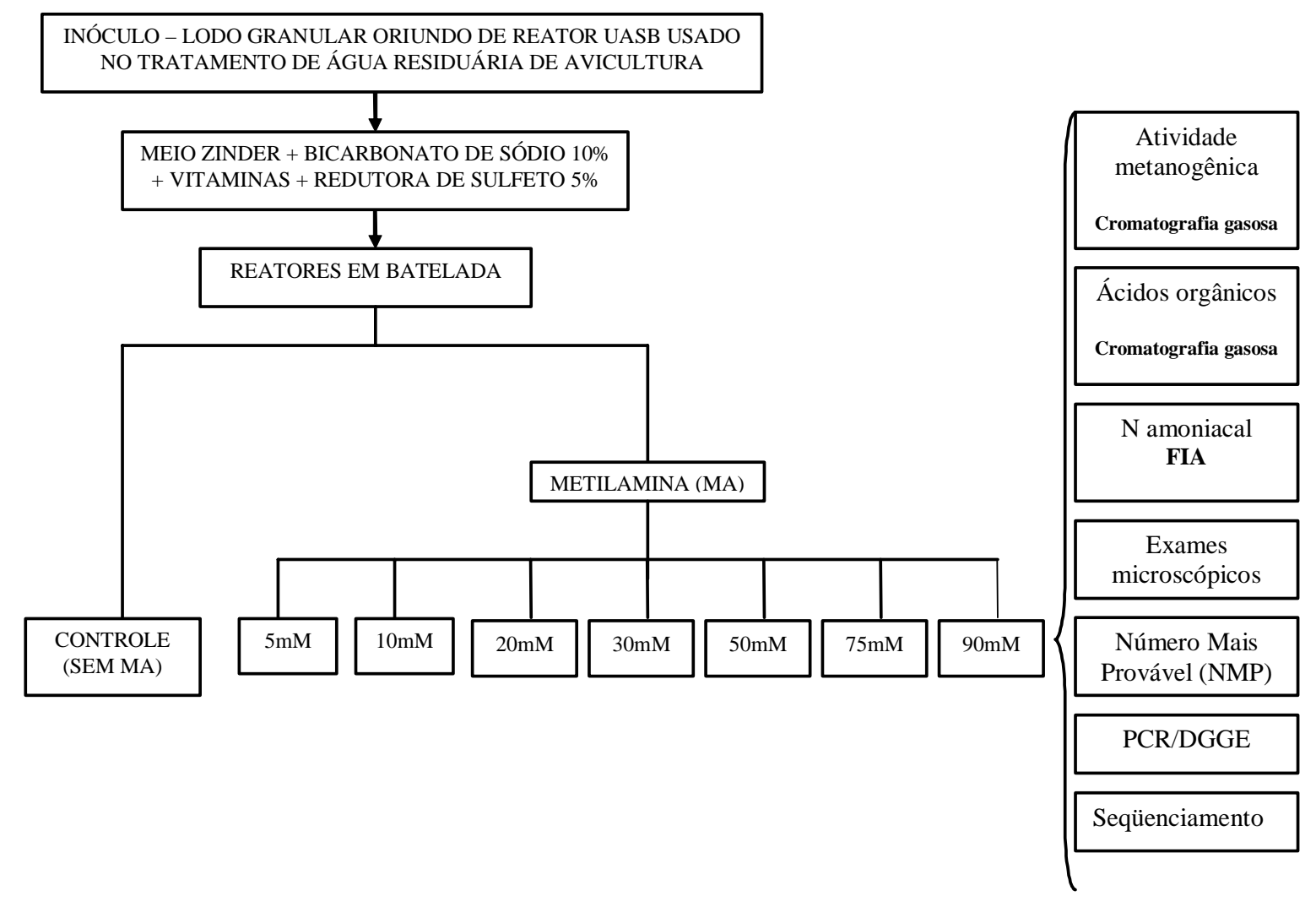

Figura 4.1. Fluxograma experimental 


\subsection{Montagem e operação dos reatores anaeróbios em batelada}

O experimento foi realizado em duplicata - reatores (1) e (2), em condições controle (sem metilamina), e com 5mM, 10mM, 20mM, 30mM, 50mM, 75mM e 90mM de metilamina. Os frascos reatores usados foram de 2000mL (Duran), com volume útil de $1000 \mathrm{~mL}$ e headspace de 1000mL (Figura 4.2).

Para inoculação, o lodo foi previamente lavado, desfragmentado e mantido sob atmosfera de $\mathrm{N}_{2}(100 \%)$ à temperatura ambiente. A inoculação foi feita em meio Zinder, previamente tamponado e reduzido, sob atmosfera de $\mathrm{N}_{2} / \mathrm{CO}_{2}(70: 30 \% \mathrm{v} / \mathrm{v})$. Os frascos foram fechados com tampa de butila e rosca plástica com abertura central. Durante todo o experimento, não houve despressurização dos frascos. A incubação foi feita em estufa (Figura 4.3), sob agitação de $150 \mathrm{rpm}$ (DOMINGUES, 2002) e temperatura de $30^{\circ} \mathrm{C} \pm$ $2^{\circ} \mathrm{C}$. A fonte de carbono (metilamina) foi adicionada por meio de seringas de plástico estéreis, após prévio consumo da matéria orgânica proveniente do inóculo. Os volumes das soluções para cada concentração estão apresentados na Tabela 4.1.

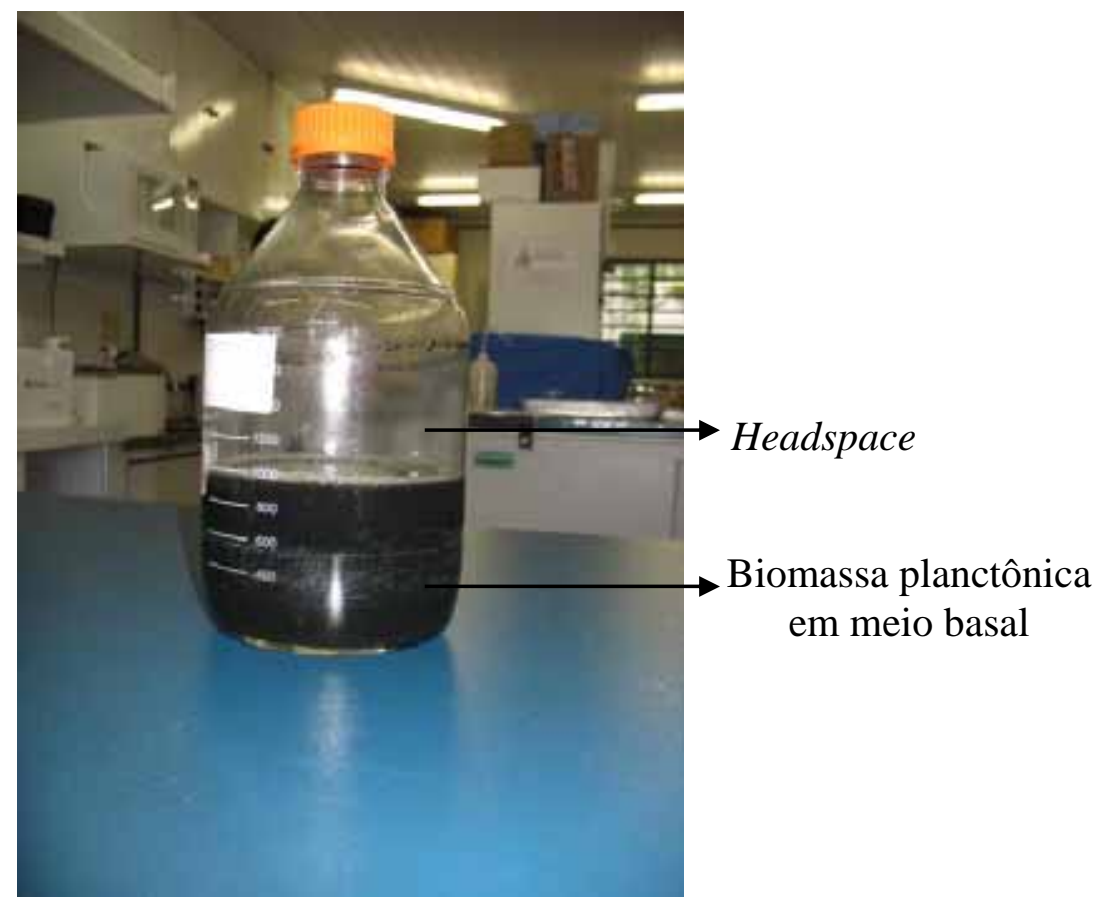

Figura 4.2. Reator anaeróbio em batelada 
Tabela 4.1. Volumes das soluções usadas nos reatores anaeróbios em batelada

\begin{tabular}{|c|c|c|c|c|c|c|}
\hline $\begin{array}{r}\text { Concentração } \\
\text { de Metilamina }\end{array}$ & $\begin{array}{c}\text { Meio } \\
\text { Zinder }\end{array}$ & $\begin{array}{r}\text { Bicarb. de } \\
\text { Sódio } 10 \% \\
\end{array}$ & $\begin{array}{l}\text { Solução de } \\
\text { Vitaminas }\end{array}$ & $\begin{array}{c}\text { Redutora } \\
\text { de Sulfeto } \\
5 \%\end{array}$ & $\begin{array}{c}\text { Inóculo } \\
(5 g / L)\end{array}$ & $\begin{array}{c}\text { Metilamina } \\
5 \mathrm{M}\end{array}$ \\
\hline Controle (0g/L) & $878 \mathrm{~mL}$ & & & & & - \\
\hline $5 \mathrm{mM}(155 \mathrm{mg} / \mathrm{L})$ & $877 \mathrm{~mL}$ & & & & & $1 \mathrm{~mL}$ \\
\hline $\begin{array}{l}10 \mathrm{mM} \\
(311 \mathrm{mg} / \mathrm{L})\end{array}$ & $876 \mathrm{~mL}$ & & & & & $2 \mathrm{~mL}$ \\
\hline $\begin{array}{l}20 \mathrm{mM} \\
(622 \mathrm{mg} / \mathrm{L})\end{array}$ & $874 \mathrm{~mL}$ & $10 \mathrm{~mL}$ & $10 \mathrm{~mL}$ & $10 \mathrm{~mL}$ & $102 \mathrm{~mL}$ & $4 \mathrm{~mL}$ \\
\hline $\begin{array}{l}30 \mathrm{mM} \\
(933 \mathrm{mg} / \mathrm{L})\end{array}$ & $872 \mathrm{~mL}$ & & & & & $6 \mathrm{~mL}$ \\
\hline $50 \mathrm{mM}(1,55 \mathrm{~g} / \mathrm{L})$ & $868 \mathrm{~mL}$ & & & & & $10 \mathrm{~mL}$ \\
\hline $75 \mathrm{mM}(2,33 \mathrm{~g} / \mathrm{L})$ & $863 \mathrm{~mL}$ & & & & & $15 \mathrm{~mL}$ \\
\hline $90 \mathrm{mM}(2,79 \mathrm{~g} / \mathrm{L})$ & $860 \mathrm{~mL}$ & & & & & $18 \mathrm{~mL}$ \\
\hline
\end{tabular}

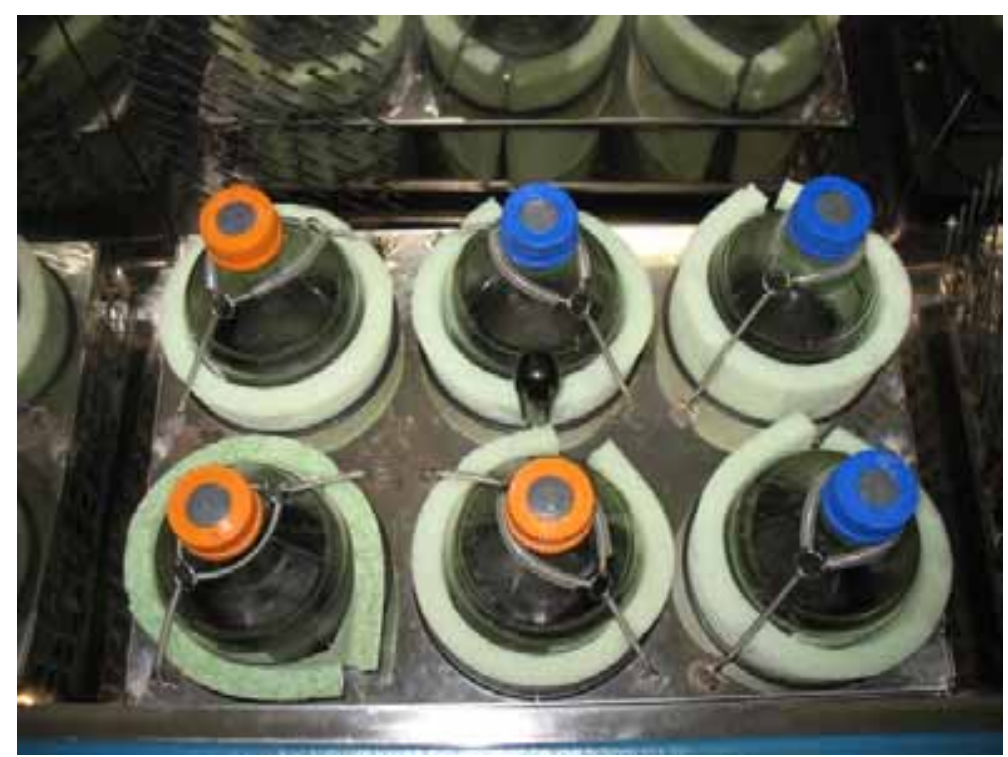

Figura 4.3. Reatores anaeróbios em batelada

\subsection{Composição e preparo do meio de cultura e soluções estoque}

\subsubsection{Meio basal Zinder}

O meio de cultivo Zinder (ZINDER et al., 1984) foi preparado em 1000mL de água ultrapurificada, e está descrito na Tabela 4.2. Os sais minerais e reagentes foram dissolvidos na ordem dada na tabela e submetidos à atmosfera de nitrogênio (100\%). 
Tabela 4.2. Composição do meio basal Zinder

\begin{tabular}{l|c}
\hline Componentes & Quantidade (q.s.p. 1000 mL) \\
\hline $\mathrm{NH}_{4} \mathrm{Cl}$ & $0,5 \mathrm{~g}$ \\
$\mathrm{MgCl}_{2} \cdot 6 \mathrm{H}_{2} \mathrm{O}$ & $0,4 \mathrm{~g}$ \\
$\mathrm{KH}_{3} \mathrm{PO}_{4}$ & $0,1 \mathrm{~g}$ \\
$\mathrm{CaCl}_{2} \cdot 2 \mathrm{H}_{2} \mathrm{O}$ & $0,05 \mathrm{~g}$ \\
Solução de Resarzurina $0,1 \%$ & $1,0 \mathrm{~mL}$ \\
Solução Traço de Metais & $10,0 \mathrm{~mL}$ \\
\hline
\end{tabular}

Fonte: ZINDER et al. (1984)

\subsubsection{Solução traço de metais}

A solução traço de metais foi preparada pela dissolução inicial de NTA (ácido nitriloacético) em 200mL de água ultrapurificada. Elevou-se imediatamente o pH para 7,0 com solução de $\mathrm{KOH} 10 \% \mathrm{~m} / \mathrm{v}$. Os demais sais foram dissolvidos na ordem e quantidade apresentada na Tabela 4.3, e o volume foi completado para 1000mL. Sob atmosfera de nitrogênio (100\%) por 20 minutos, a solução foi dividida em dois frascos Duran SCHOTT ${ }^{\circledR}$ de $500 \mathrm{~mL}$. Os frascos foram então fechados sob anaerobiose, autoclavados a $121^{\circ} \mathrm{C}$ e $1 \mathrm{~atm}$ durante 20 minutos e armazenados a $4^{\circ} \mathrm{C}$.

Tabela 4.3. Composição da solução traço de metais

\begin{tabular}{l|c}
\hline Componentes & Quantidade (q.s.p. 1000 mL) \\
\hline $\mathrm{NTA}$ & $4,5 \mathrm{~g}$ \\
$\mathrm{FeSO}$ & $0,556 \mathrm{~g}$ \\
$\mathrm{MnSO}_{4} \cdot \mathrm{H}_{2} \mathrm{O}$ & $0,086 \mathrm{~g}$ \\
$\mathrm{CoCl}_{2} \cdot 6 \mathrm{H}_{2} \mathrm{O}$ & $0,17 \mathrm{~g}$ \\
$\mathrm{ZnSO}_{4} \cdot 7 \mathrm{H}_{2} \mathrm{O}$ & $0,21 \mathrm{~g}$ \\
$\mathrm{H}_{3} \mathrm{BO}_{3}$ & $0,19 \mathrm{~g}$ \\
$\mathrm{NiCl}_{2}$ & $0,02 \mathrm{~g}$ \\
$\mathrm{Na}_{2} \mathrm{MoO}_{4}$ & $0,01 \mathrm{~g}$ \\
\hline
\end{tabular}

Fonte: ZINDER et al. (1984)

\subsubsection{Solução de vitaminas}

A solução de vitaminas foi preparada adicionando-se os ingredientes da Tabela 4.4 em 1000mL de água ultrapurificada previamente fervida por aproximadamente 15 minutos submetida a atmosfera de $\mathrm{N}_{2}$ (100\%). A solução final foi esterilizada a frio em sistema Millipore com membrana de tamanho de poros de 0,22 $\mu$ m e armazenada em frascos sob condições de assepsia. No final os frascos foram armazenados a $4^{\circ} \mathrm{C}$. 
Tabela 4. 4. Composição da solução de vitaminas

\begin{tabular}{l|c}
\hline Componentes & Quantidade (q.s.p. 1000 mL) \\
\hline Biotina & $0,002 \mathrm{~g}$ \\
Ácido Fólico & $0,002 \mathrm{~g}$ \\
Tiamina.HCl & $0,005 \mathrm{~g}$ \\
Riboflavina & $0,005 \mathrm{~g}$ \\
Ácido Nicotínico & $0,005 \mathrm{~g}$ \\
Pantotenato de Cálcio & $0,005 \mathrm{~g}$ \\
Piridoxina.HCl & $0,010 \mathrm{~g}$ \\
Vitamina B B & $0,0001 \mathrm{~g}$ \\
Ácido Lipóico & $0,005 \mathrm{~g}$ \\
\hline
\end{tabular}

Fonte: TOUZEL \& ALBAGNAC (1983); DUBOURGUIER (1987)

\subsubsection{Solução de bicarbonato de sódio}

A solução estoque de bicarbonato de sódio $10 \%(\mathrm{~m} / \mathrm{v})$ foi preparada pela dissolução de $10 \mathrm{~g}$ desse reagente em $100 \mathrm{~mL}$ de água ultrapurificada previamente fervida. Após o resfriamento da água à temperatura de aproximadamente $40^{\circ} \mathrm{C}, \mathrm{o}$ bicarbonato de sódio foi dissolvido e submetido à atmosfera de $\mathrm{N}_{2}$ (100\%) por aproximadamente 20 minutos. A solução foi filtrada em sistema Millipore ${ }^{\circledR}$, distribuída em frascos de antibiótico previamente esterilizados, e mantida à temperatura ambiente sob ausência de luz.

\subsubsection{Solução redutora de sulfeto de sódio}

Para o preparo da solução redutora, $\mathrm{Na}_{2} \mathrm{~S} .9 \mathrm{H}_{2} \mathrm{O} 5 \%(\mathrm{~m} / \mathrm{v})$ foi transferido para papel de filtro para secagem sob pressão com espátula plástica, para eliminar o excesso de água. O sal foi dissolvido em água ultrapurificada previamente fervida e submetida a atmosfera de $\mathrm{N}_{2}$ (100\%), por aproximadamente 20 minutos. A solução foi esterilizada por filtração em sistema Millipore ${ }^{\circledR}$ e armazenada à temperatura ambiente e sob ausência de luz, em frascos de antibiótico previamente esterilizados. 


\subsubsection{Solução estoque de metilamina}

Para o preparo de solução estoque de metilamina, usada como fonte de carbono nos reatores anaeróbios, foi escolhida a concentração de 5M. Como a metilamina pura mostrou-se muito volátil, a solução foi preparada com cloridrato de metilamina $\left(\mathrm{CH}_{3} \mathrm{NH}_{2}-\mathrm{HCl}\right)$, da Sigma-Aldrich, solúvel em água. O sal foi dissolvido em água ultrapurificada e armazenado em frascos de antibiótico.

\subsection{Manutenção da anaerobiose}

A anaerobiose foi mantida através da troca gasosa da atmosfera dos frascos através de sistema de distribuição simultânea de gases. Este compreende um sistema tubular (tubos de cobre) de transporte dos gases dos cilindros estoque (White Martins) para quatro saídas com válvulas, que controlam a vazão do gás. Em cada válvula, uma mangueira de aproximadamente $30 \mathrm{~cm}$ foi conectada e, em sua extremidade, foi acoplada uma seringa. Para o uso de gases em sistemas estéreis, um filtro estéril da marca Corning ${ }^{\circledR}$, constituído de uma membrana com porosidade de $0,25 \mu \mathrm{m}$, foi ligado à seringa. Para injeção dos gases, as tampas dos frascos foram perfuradas por agulha estéril também acoplada ao filtro. Este sistema foi adaptado por VAZOLLER (1995).

\subsection{Limpeza e assepsia}

\subsubsection{Limpeza da vidraria}

A vidraria foi lavada com Extran diluído em água de torneira (5\% v/v), enxaguada em água corrente diversas vezes para remoção total do detergente. Depois de nova lavagem com água destilada, a vidraria foi posta para secar em estufa ou estantes.

\subsubsection{Esterilização a frio}

A esterilização a frio foi feita por filtração em sistema Millipore ${ }^{\circledR}$, e empregou membranas de tamanho de poros de $0,22 \mu \mathrm{m}$. A solução de vitaminas, solução tampão (bicarbonato de sódio) e solução redutora (sulfeto), já descritas, foram esterilizadas a frio. Para manter condições de assepsia, foram usados forno e bico de Bunsen. As 
soluções, previamente submetidas a atmosfera de $\mathrm{N}_{2}$ (100\%), foram filtradas à vácuo e distribuídas em frascos de antibiótico e Duran SCHOTT ${ }^{\circledR}$ com o auxílio de pipetas de diferentes volumes. Todo o material usado foi previamente esterilizado em autoclave $\left(121^{\circ} \mathrm{C}\right.$ e $1 \mathrm{~atm}$ por 20 minutos).

\subsubsection{Esterilização em calor úmido}

Os meios de cultura e solução traço de metais, assim como o sistema de filtração, vidrarias, seringas e agulhas usadas, foram esterilizados em calor úmido. Para isso, o material foi envolto em papéis alumínio e pardo e autoclavado em condições de $121^{\circ} \mathrm{C}$ e $1 \mathrm{~atm}$ de pressão, por 20 minutos.

\subsection{Análises cromatográficas}

\subsubsection{Determinação de metano}

A concentração de metano no biogás foi monitorada através de cromatografia gasosa. Alíquotas de $1 \mathrm{~mL}$ do headspace dos reatores foram retiradas com auxílio de seringa com válvula de trava (1,0mL da VICI precision sampling, Inc.) e analisadas no cromatógrafo a gás.

Utilizou-se cromatógrafo Gow-Mac Instrument Co, modelo 69, com coluna Porapak-Q (comprimento de 2,0m e diâmetro interno de 1/4") com detector de condutividade térmica, série 150; o gás de arraste usado foi o hidrogênio super seco (White Martins). O integrador era da marca Hewlett-Packard, modelo HP 3396, série II. As condições de operação do aparelho foram: temperatura do detector, coluna e injetor $55^{\circ} \mathrm{C}$ e corrente de $150 \mathrm{~mA}$.

Para o cálculo da concentração do gás metano $\left(\mathrm{mmol}\right.$ de $\left.\mathrm{CH}_{4} / \mathrm{L}\right)$ foi preparada curva analítica (calibração) do metano (ANEXO 1).

\subsubsection{Avaliação da atividade metanogênica}

O ensaio constituiu na determinação, por cromatografia gasosa, da concentração de metano, presente no biogás produzido no volume livre (headspace) dos reatores de 
2000mL. Sua finalidade foi avaliar o potencial da biomassa na conversão de substrato (fonte de carbono na forma de metilamina) em metano.

Essa análise foi realizada durante todo o experimento, em freqüência aproximada de quatro vezes ao dia.

\subsubsection{Cálculo da atividade metanogênica específica}

A metodologia usada para o cálculo da atividade metanogênica foi adaptada dos trabalhos de ARAÚJO (1995), OLIVEIRA (1997) e STEIL (2001).

Os valores das áreas de metano obtidas foram convertidos, por meio da equação da reta padrão, a mmols de $\mathrm{CH}_{4}$ nas CNTP. Os valores de metano obtidos para $1 \mathrm{~mL}$ (volume retirado para a amostragem) foram convertidos para o headspace de cada frasco, a partir da seguinte equação:

$n^{\circ}$ de mols de $\mathrm{CH}_{4}$ no headspace $(\mathrm{mmol})=\left[\mathrm{CH}_{4}\right]$ na amostra $(\mathrm{mmol}) \mathrm{X}$ volume do headspace $(\mathrm{mL})$ /volume injetado da amostra $(\mathrm{mL})$

Durante todo o experimento, os frascos não foram despressurizados, a fim de se manter concentrações acumuladas do biogás.

Os dados experimentais foram ajustados à sigmóide de Boltzmann (Equação 1) através do software Microcal Origin ${ }^{\circledR} 7.5$ utilizando-o algoritmo de otimização de Levenberg-Marquardt, minimizando a somatória dos erros ao quadrado. A sigmóide ajustada foi posteriormente derivada, numericamente, com o mesmo software, a fim de se determinar as velocidades máximas de formação de metano. Dividindo-se o valor da velocidade máxima pela concentração de biomassa de cada reator (g SVT), obteve-se a atividade metanogênica aparente (AMA).

$Y=\frac{A_{1}-A_{2}}{1+e^{\left(x-x_{0}\right)} / d_{x}}+A_{2}$

A atividade metanogênica específica (AME) foi obtida subtraindo-se a atividade metanogênica do controle dos valores das atividades obtidas com a adição de metilamina.

A concentração da biomassa em cada frasco reator foi determinada pela média entre os valores de sólidos suspensos voláteis iniciais e finais. 


\subsubsection{Determinação de ácidos orgânicos voláteis}

Para determinação cromatográfica gasosa dos ácidos orgânicos voláteis, retirouse dos reatores alíquotas de $5 \mathrm{~mL}$ de amostra. As amostras foram retiradas no início e final do experimento e congeladas em frascos de antibiótico para posterior análise.

Na ocasião da análise, as amostras foram transferidas para tubos de ensaio, onde foi adicionado 0,5g de $\mathrm{NaCl}, 50 \mu \mathrm{L}$ de solução de $\mathrm{H}_{2} \mathrm{SO}_{4}, 70 \mu \mathrm{L}$ de solução de ácido crotônico (padrão interno) e 0,60mL de éter etílico. Os frascos foram tampados, agitados manualmente por 1 minuto e então centrifugados a 1000rpm e armazenados em congelador para posterior injeção no cromatógrafo (MORAES et al, 2000).

Utilizou-se cromatógrafo Hewlett-packard, modelo CG, HP 6890, com coluna HP - INNOWAX de comprimento 30m e diâmetro interno $25 \mu \mathrm{m}$. O gás de arraste usado foi o hidrogênio, com vazão de $30 \mathrm{~mL} / \mathrm{min}$ e detector de ionização de chama. $\mathrm{O}$ aparelho foi operado sob as seguintes condições: temperatura do detector $300^{\circ} \mathrm{C}$ e do injetor $250^{\circ} \mathrm{C}$ - a coluna foi aquecida a $100^{\circ} \mathrm{C}$ por 3 minutos e em seguida aplicou-se gradiente de temperatura (rampa de aquecimento) de $5^{\circ} \mathrm{C} / \mathrm{min}$ até atingir $180^{\circ} \mathrm{C}$; fluxo de ar 300mL/min. O volume injetado foi de $1 \mu$ l, usando-se seringa SGE de $10 \mu l$.

\subsection{Análises físico-químicas}

\subsubsection{Determinação de nitrogênio amoniacal}

As concentrações de nitrogênio amoniacal foram realizadas no início e final do experimento, para todos os reatores anaeróbios, por meio de análise de injeção de Fluxo (FIA do inglês Flow Injection Analyses). As amostras foram retiradas em alíquotas de $5 \mathrm{~mL}$, acidificadas com $100 \mu \mathrm{l}$ de $\mathrm{HCl}$ diluído e analisadas de acordo com metodologia descrita em APHA (2001). 


\subsubsection{Determinação de sólidos voláteis totais}

A determinação dos sólidos voláteis totais (SVT) foi feita em triplicata, com o inóculo e após o término do experimento, de acordo com o APHA (2001). Neste trabalho, os resultados das análises de sólidos estão expressos em g/L.

\subsection{Análise da diversidade microbiana}

\subsubsection{Exames microscópicos}

As amostras examinadas ao microscópio foram o inóculo, as células de todos os reatores anaeróbios em batelada e as provenientes dos experimentos de contagem por NMP. As amostras foram examinadas sob luz comum, contraste de fase e fluorescência. Uma gota de amostra foi colocada em fina camada de ágar $2 \%$ solidificado, disposto entre lâmina e lamínula, para diminuir o movimento das células.

Utilizou-se microscópio Leica DM LB, acoplado a câmara Leica DC 200 e software Image-Pro plus (versão 4.5.0.19). Foram usadas as seguintes condições de aumento: ocular 10, objetiva 100 e zoom de 1,25.

\subsubsection{Avaliação quantitativa dos grupos microbianos anaeróbios}

A técnica do Número Mais Provável (NMP) foi realizada ao final do experimento para quantificação dos grupos microbianos anaeróbios (bactérias anaeróbias totais e arquéias metanogênicas). O método constituiu na inoculação do lodo proveniente dos diferentes reatores, após duas semanas de operação.

Anteriormente à inoculação nos frascos de contagem do NMP, procedeu-se a diluição do inóculo em condições anaeróbias. Para tanto, foi utilizado meio basal Zinder, acrescido de bicarbonato de sódio (10\%) e solução redutora de sulfeto de sódio (5\%), sob atmosfera de $\mathrm{N}_{2} / \mathrm{CO}_{2}$. Foram usados frascos de $30 \mathrm{~mL}$, sendo $10 \mathrm{~mL}$ de volume de solução contendo $9 \mathrm{~mL}$ de água de diluição e $1 \mathrm{~mL}$ de inóculo. Os frascos foram incubados a $30^{\circ} \mathrm{C} \pm 2{ }^{\circ} \mathrm{C}$ durante 15 dias.

As diluições estiveram na faixa de $10^{-1}$ a $10^{-10}$ e foram feitas em quintuplicata (Figura 4.4). Após período de incubação de 15 dias, o crescimento dos microrganismos 
foi avaliado pela presença de turbidez, formação de biogás e microscopia óptica de contraste de fases e de fluorescência.

Combinações de respostas positivas foram a base do cálculo para estimar o NMP, usando a tabela padrão de probabilidade (APHA, 2005), que confere o limite de confiança de $95 \%$ para cada valor determinado.

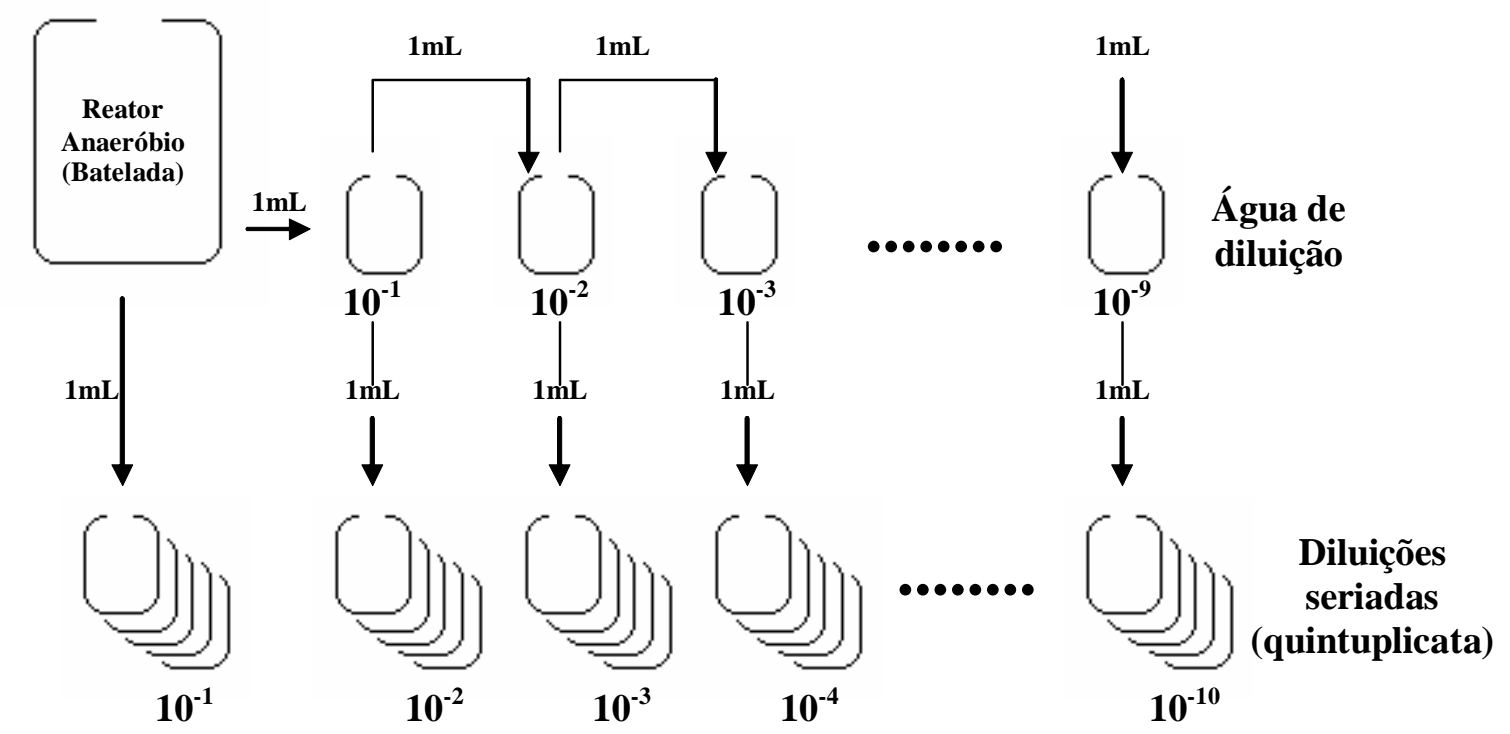

Figura 4.4. Esquema de diluição do NMP

\subsubsection{Análise de Biologia Molecular}

A avaliação da diversidade da comunidade microbiana foi realizada através da técnica do PCR/DGGE. O DNA foi extraído segundo o protocolo de GRIFFITHS et al. (2000). Na amplificação dos fragmentos do DNA foram usados primers específicos do Domínio Bacteria (NIELSEN et al., 1999) e Domínio Archaea (KUDO et al., 1997). Os fragmentos de DNA amplificados foram separados pela eletroforese em gel de gradiente desnaturante - DGGE.

A partir do DNA extraído da amostra foram obtidos fragmentos DNAr 16S, utilizando a técnica da amplificação, através da reação de polimerização em cadeia (PCR) com primers homólogos às regiões conservadas do gene RNAr 16S.

A Tabela 4.5 descreve os primers dos domínios Bacteria e Archaea utilizados nas análises de PCR/DGGE. 
Tabela 4.5. Primers usados nas análises de PCR

\begin{tabular}{|c|c|c|}
\hline Domínio & Primers e seqüência (5’ $\rightarrow$ 3’) & Fonte \\
\hline Archaea & $\begin{array}{l}\text { 1100 FGC (5'- AACCGTCGACAG TCAGGYAACGAG } \\
\text { CGAG-3')- } \\
\mathbf{1 4 0 0} \mathbf{R} \text { (5'- CGCCGAATTCGTGCAAGGAGCAGG } \\
\text { GAC-3') } \\
\text { GC clamp (5' - CGCCCGCCGCGCGCGGCGGGCGGG } \\
\text { GCGGGGGCACGGGGGG-3') }\end{array}$ & Kudo et al. (1997) \\
\hline Bacteria & $\begin{array}{l}\mathbf{9 6 8} \text { FGC (5'- AACGCGAAGAACCTTAC - 3’) } \\
\mathbf{1 3 9 2} \text { R (5’- AACGGGCGGTGTGTAC - 3’) } \\
\text { GC clamp (5'- CGCCCGCCGGGGCGCGCCCCGGGC } \\
\text { GGGGCGGGGGCACGGGGGG - 3') }\end{array}$ & Nielsen et al. (1999) \\
\hline
\end{tabular}

A agarose em gel eletroforético foi usada para avaliar o produto resultante da extração dos ácidos nucléicos e da amplificação dos genes por PCR.

O procedimento para a avaliação da extração dos ácidos nucléicos e da amplificação do PCR foi o mesmo; a única diferença foi o marcador usado. Para a extração dos ácidos nucléicos foi usada concentração de agarose de 1\% e marcador High DNA Mass Ladder. Para verificar o produto da amplificação por PCR utilizou-se marcador Low DNA Mass Ladder.

O procedimento para realização do DGGE consistiu na preparação da solução do gel nas concentrações desejadas (40\%-65\% para Bacteria e 30\%-60\% para Archaea); depois disso, preparou-se o "sanduíche" com o kit de placas de vidro e suporte. Os géis foram preparados e transferidos simultaneamente para o “sanduíche” de placas. Colocou-se o pente e esperou-se a solidificação dos géis. A câmara eletroforética foi preparada adicionando-se $140 \mathrm{~mL}$ de TAE 50X e volume de 7 litros foi completado com água ultrapurificada. A solução foi posta para aquecer a temperatura de $65^{\circ} \mathrm{C}$ e, após atingi-la, recebeu o kit de placas. As alíquotas, preparadas com a mistura de $20 \mu \mathrm{L}$ de amostra com $4 \mu \mathrm{L}$ de loading dye, foram transferidas para as cavidades do gel.

A bomba de agitação foi ligada e decorreu tempo de corrida de 6 horas a $60^{\circ} \mathrm{C}$ para Bacteria e 16 horas e $65^{\circ} \mathrm{C}$ para Archaea.

Utilizou-se sistema de DGGE D Code ${ }^{\mathrm{TM}}$ - Universal Mutation Detection System (Bio-Rad, Inc., Hercules, Califórnia) exatamente como descrito pelos fabricantes no manual de instruções. Os géis foram corados com 10mL de solução de coloração (TAE 1x contendo $1 \mu \mathrm{g} / \mathrm{mL}$ de Brometo de Etídeo) por 20 minutos, fotografados em câmara 
escura Eagle Yey II (Stratagene) sob exposição à UV de 254nm e processados com o software Eaglesight (Stratagene - versão 3.22).

Na comparação dos padrões de bandas de DGGE, utilizou-se a equação de GILLIAN et al. (1998), que calcula o coeficiente de similaridade entre duas amostras (Equação 2).

$$
C_{s}=\frac{2 j}{(a+b) \times 100}
$$

A variável a é o número de bandas da amostra 1 , b é o número de bandas da amostra 2 e j é o número de bandas comuns. A intensidade das bandas de DGGE não foi considerada fator variável.

Amostras para seqüenciamento foram obtidas através de PCR realizado a partir das bandas do DGGE, com primers para o Domínio Archaea (KUDO et al., 1997) sem GC clamp. O seqüenciamento foi feito no Centro de Estudos de Genoma Humano do Instituto de Ciências Biomédicas (ICB) - USP. O resultado do seqüenciamento foi alinhado através do software DNAStar. A seqüência final obtida foi analisada através do banco de dados NCBI-BLAST. 


\section{RESULTADOS E DISCUSSÃO}

Os testes de atividade metanogênica tiveram duração aproximada de 200 horas, indicando a rápida degradação da metilamina em diferentes concentrações. Os parâmetros usados para o cálculo da atividade metanogênica estão apresentados no APÊNDICE 1.

Nos reatores controle, que não receberam adição de fonte de carbono, tendo como substrato apenas o meio basal Zinder e vitaminas, ocorreu produção de metano inferior aos que receberam adição de metilamina em diferentes concentrações. A concentração de metano acumulado ficou em torno de 2,57 mmol/L em 160 horas de experimento para o reator Controle (1). O reator Controle (2), no mesmo tempo de experimento, teve valor de metano acumulado igual a 3,25 mmol/L. Nesses reatores, não existiu fase lag, pois a produção de $\mathrm{CH}_{4}$ apresentou comportamento linear, diferente dos reatores alimentados com metilamina, que apresentaram padrão de crescimento sigmoidal. Os resultados dos reatores controle estão expressos graficamente nas Figuras 5.1 e 5.2 . 


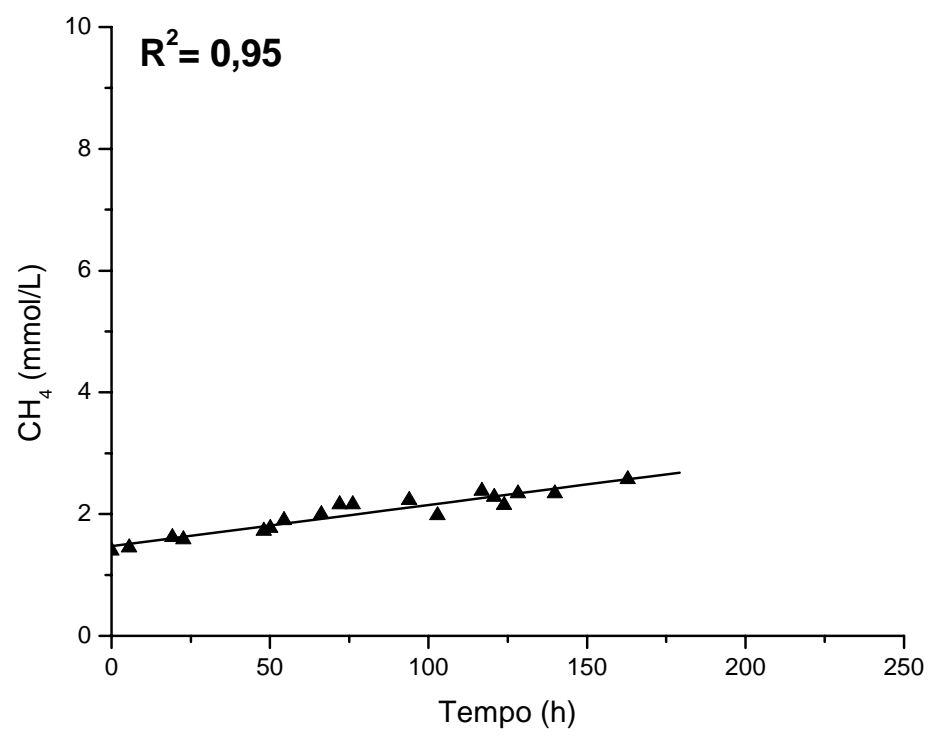

Figura 5.1. Variação temporal da produção de metano ( $\mathbf{A}$ - valores experimentais; — modelo linear ajustado) no reator anaeróbio controle (1)

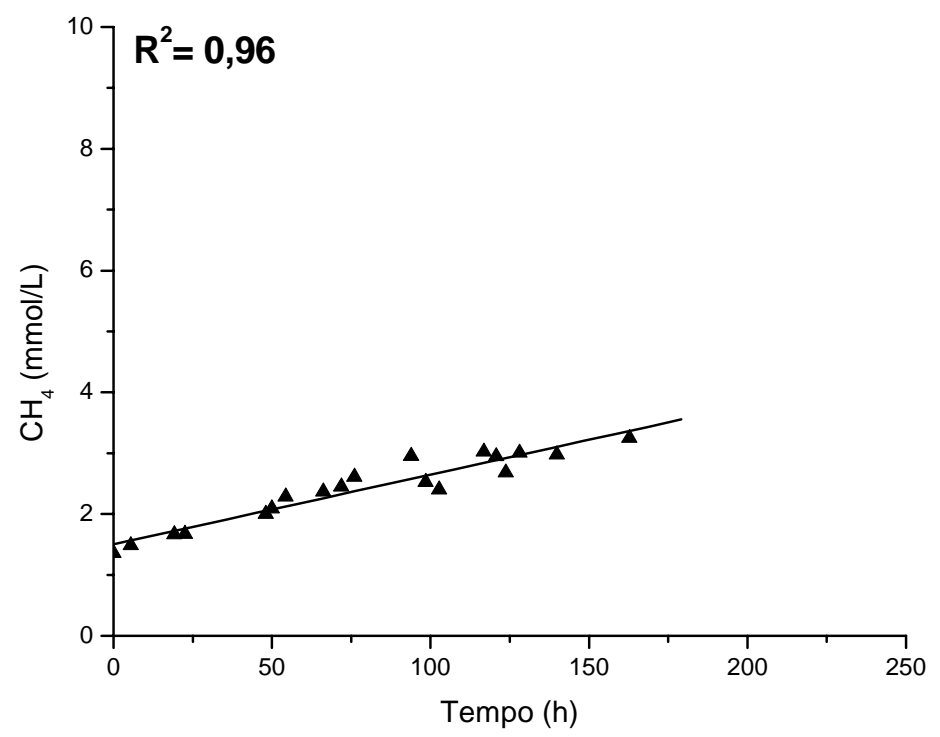

Figura 5.2. Variação temporal da produção de metano ( $\mathbf{A}$ - valores experimentais; — modelo linear ajustado) no reator anaeróbio controle (2)

Nos reatores alimentados com $5 \mathrm{mM}$ de metilamina observou-se fase lag com duração de 20 horas. Após aproximadamente 116 horas de experimento, a concentração de metano acumulado atingiu valor máximo de $6,91 \mathrm{mmol} / \mathrm{L}$ no reator 1 e $6,58 \mathrm{mmol} / \mathrm{L}$ no reator 2. Nas Figuras 5.3 e 5.4 a produção de metano nesses reatores está mostrada graficamente. 


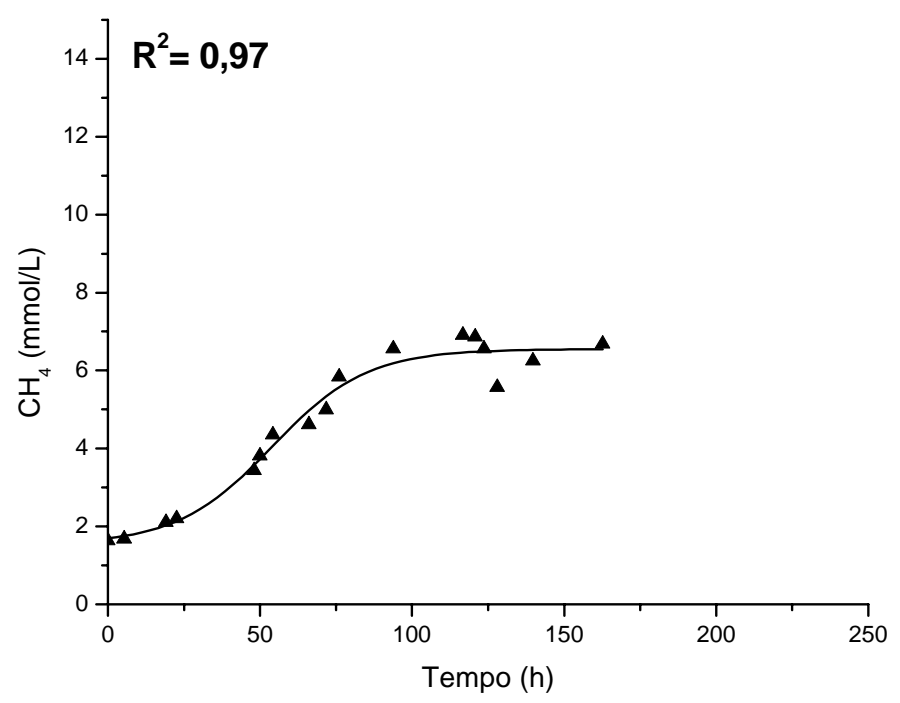

Figura 5.3. Variação temporal da produção de metano ( $\boldsymbol{\Delta}$ - valores experimentais; - modelo sigmoidal ajustado) no reator anaeróbio (1) alimentado com $5 \mathrm{mM}$ de metilamina

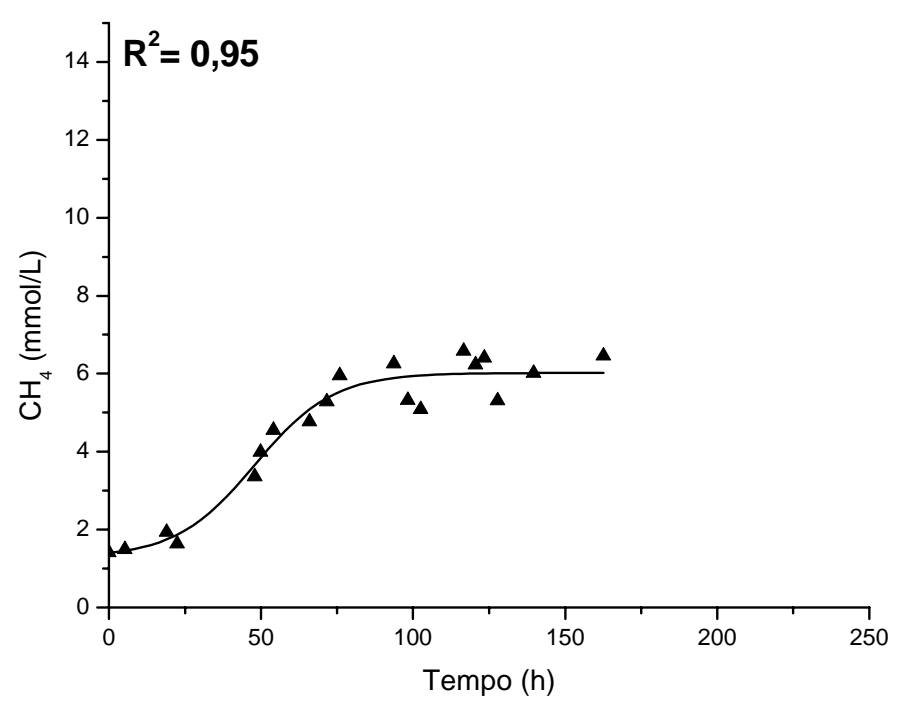

Figura 5.4. Variação temporal da produção de metano ( $\boldsymbol{\Delta}$ - valores experimentais; - modelo sigmoidal ajustado) no reator anaeróbio (2) alimentado com $5 \mathrm{mM}$ de metilamina

Nos reatores alimentados com 10mM de metilamina, a fase lag também teve duração de 20 horas. A produção máxima de metano nos reatores ocorreu após aproximadamente 120 horas e atingiram valores de 11,8 mmol/L no reator (1) e 9,44 mmol/L no reator (2). Nas Figuras 5.5 e 5.6 a produção de metano nesses reatores está mostrada graficamente. 


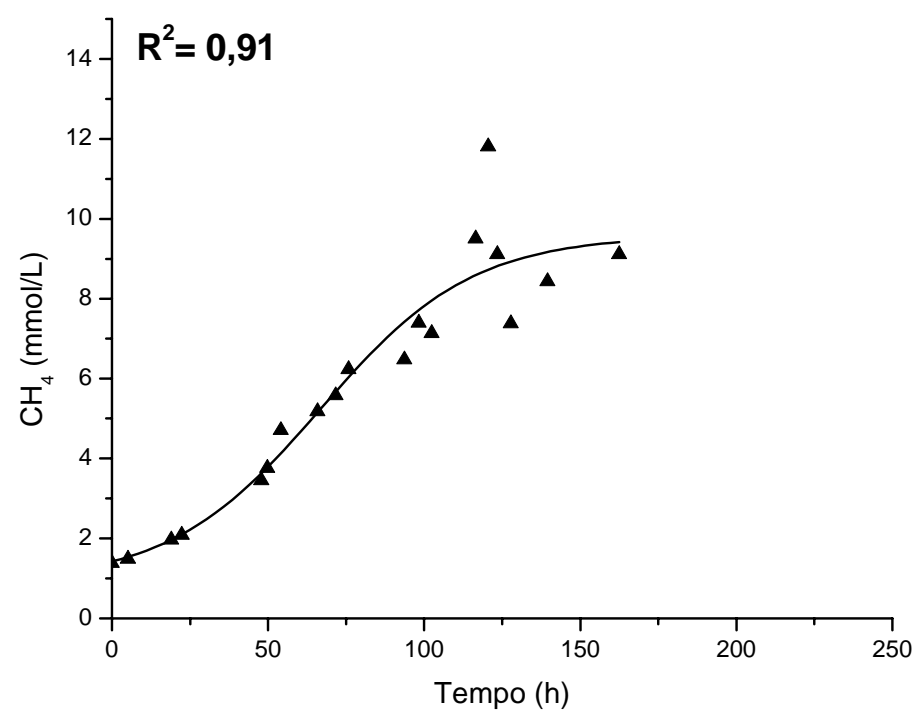

Figura 5.5. Variação temporal da produção de metano ( $\boldsymbol{\Delta}$ - valores experimentais; — modelo sigmoidal ajustado) no reator anaeróbio (1) alimentado com 10mM de metilamina

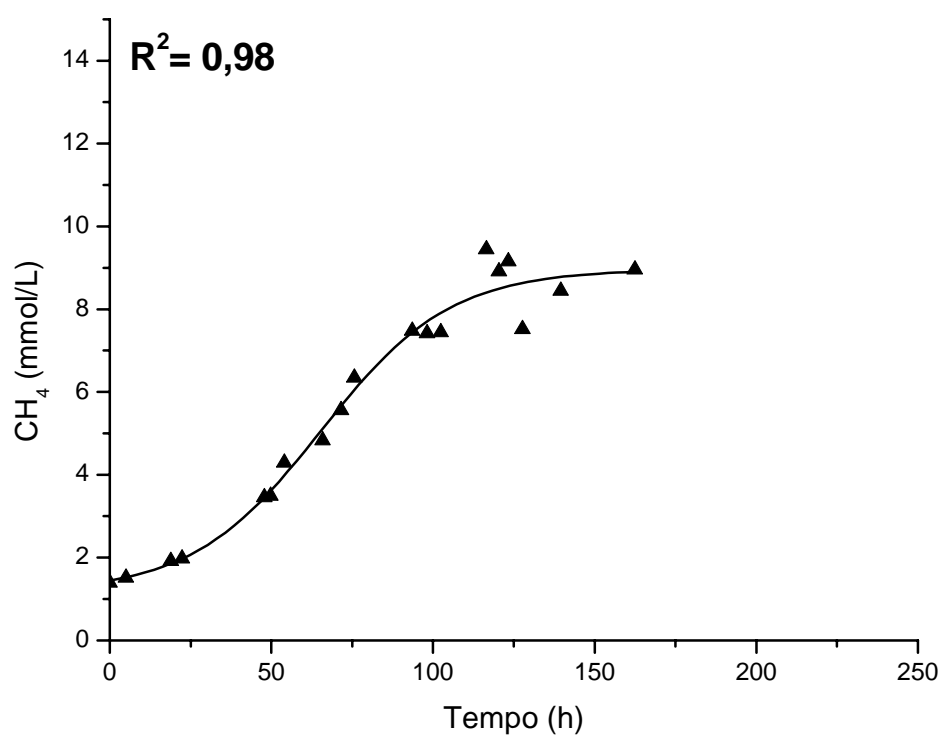

Figura 5.6. Variação temporal da produção de metano ( $\mathbf{A}$ - valores experimentais; — modelo sigmoidal ajustado) no reator anaeróbio (2) alimentado com 10mM de metilamina

Nos reatores alimentados com $20 \mathrm{mM}$ e $30 \mathrm{mM}$, a fase lag foi de 50 horas do início do experimento. Os valores máximos de metano acumulado, nos reatores com 20mM de metilamina, foram obtidos após 116 horas do início do experimento e iguais a $14,7 \mathrm{mmol} / \mathrm{L}$ no reator (1) e 15,3 mmol/L no reator (2). Nos reatores alimentados com 30mM de metilamina as concentrações máximas de metano acumulado, observadas 
após 122 horas do início do experimento, foram de $20 \mathrm{mmol} / \mathrm{L}$ no reator (1) e 20,4 $\mathrm{mmol} / \mathrm{L}$ no reator (2). Nas figuras 5.6, 5.7, 5.8 e 5.9 está mostrado graficamente a produção de metano nas duplicatas dos reatores (1) e (2) alimentados com 20mM e 30mM de metilamina.

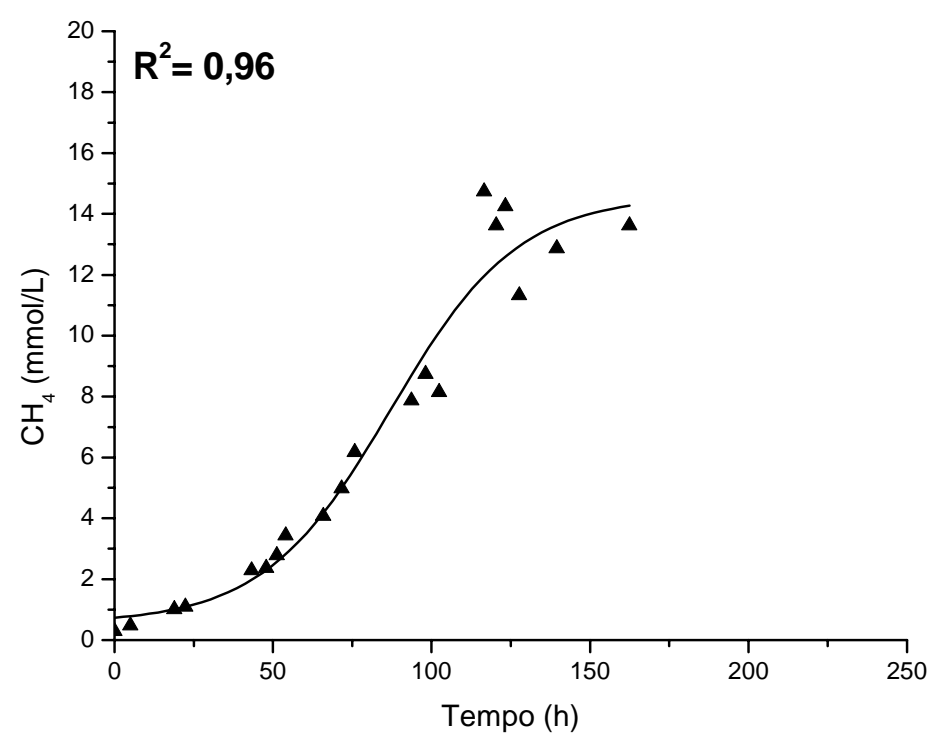

Figura 5.7. Variação temporal da produção de metano ( $\boldsymbol{\Delta}$ - valores experimentais; - modelo sigmoidal ajustado) no reator anaeróbio (1) alimentado com 20mM de metilamina

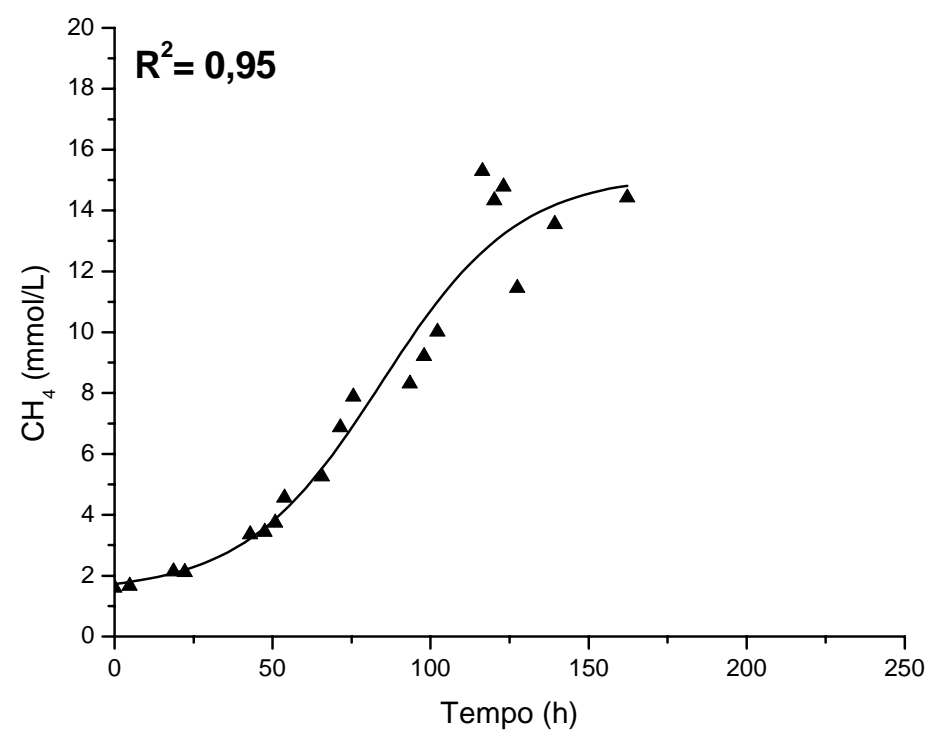

Figura 5.8. Variação temporal da produção de metano ( $\boldsymbol{\Delta}$ - valores experimentais; - modelo sigmoidal ajustado) no reator anaeróbio (2) alimentado com 20mM de metilamina 


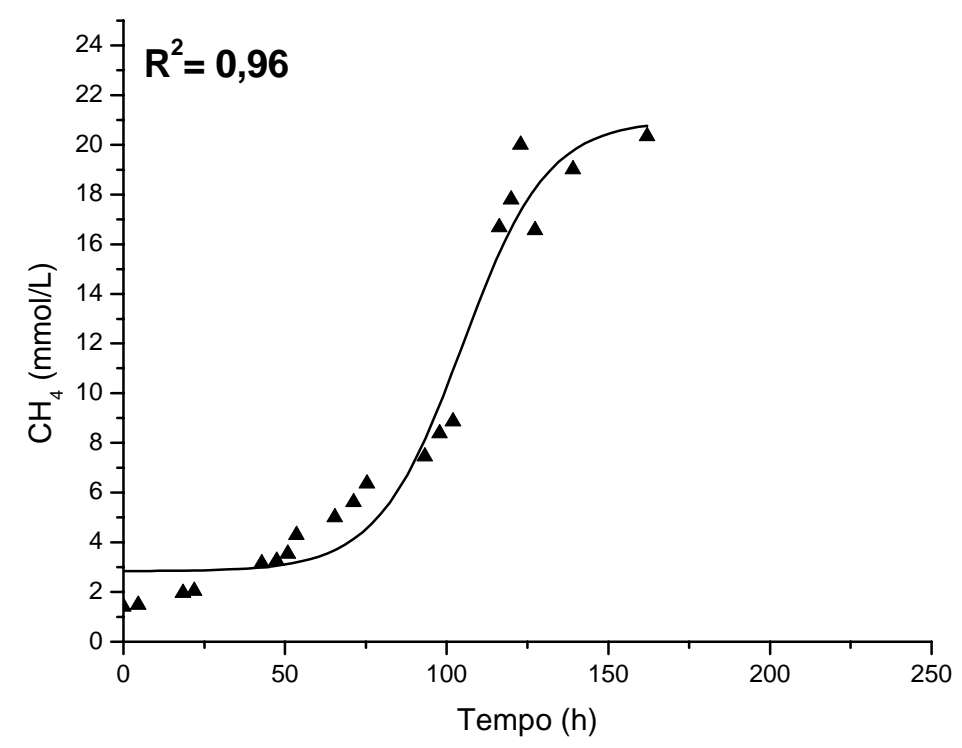

Figura 5.9. Variação temporal da produção de metano ( $\boldsymbol{\Delta}$ - valores experimentais; - modelo sigmoidal ajustado) no reator anaeróbio (1) alimentado com 30mM de metilamina

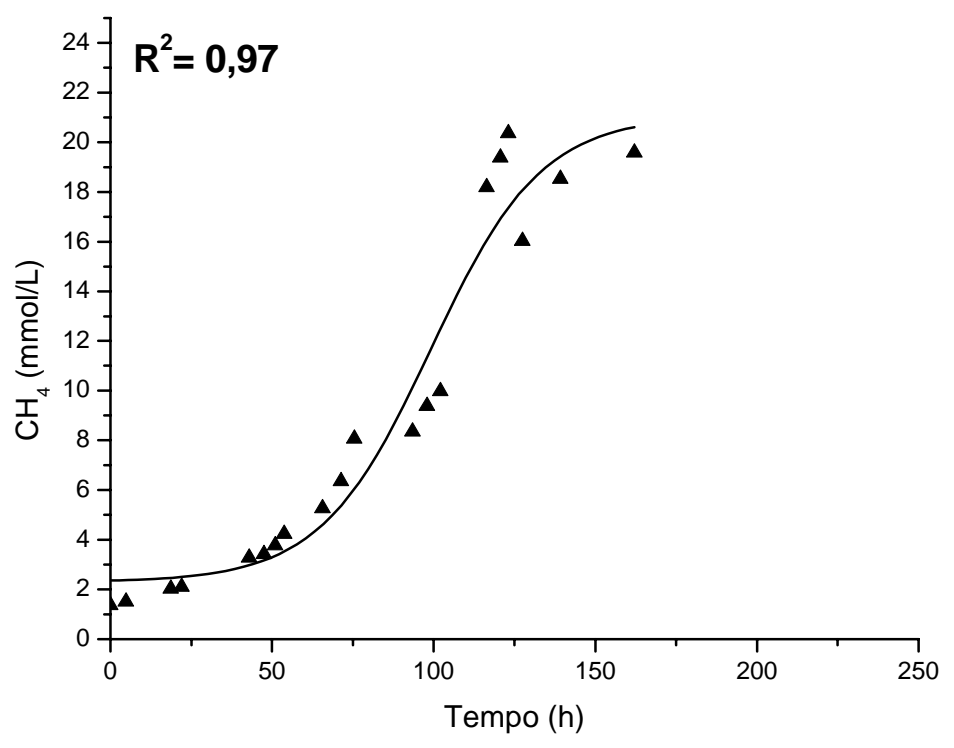

Figura 5.10. Variação temporal da produção de metano ( $\boldsymbol{\Lambda}$ - valores experimentais; - modelo sigmoidal ajustado) no reator anaeróbio (2) alimentado com 30mM de metilamina

Nos reatores alimentados com 50mM de metilamina, a fase lag teve duração de 100 horas. No reator (1) o valor máximo de metano acumulado foi igual a 37,3 mmol/L, após 170 horas. No reator (2) ocorreu o mesmo valor, após 175 horas. Nas Figuras 5.11 e 5.12 está mostrado graficamente a produção de metano nesses reatores. 


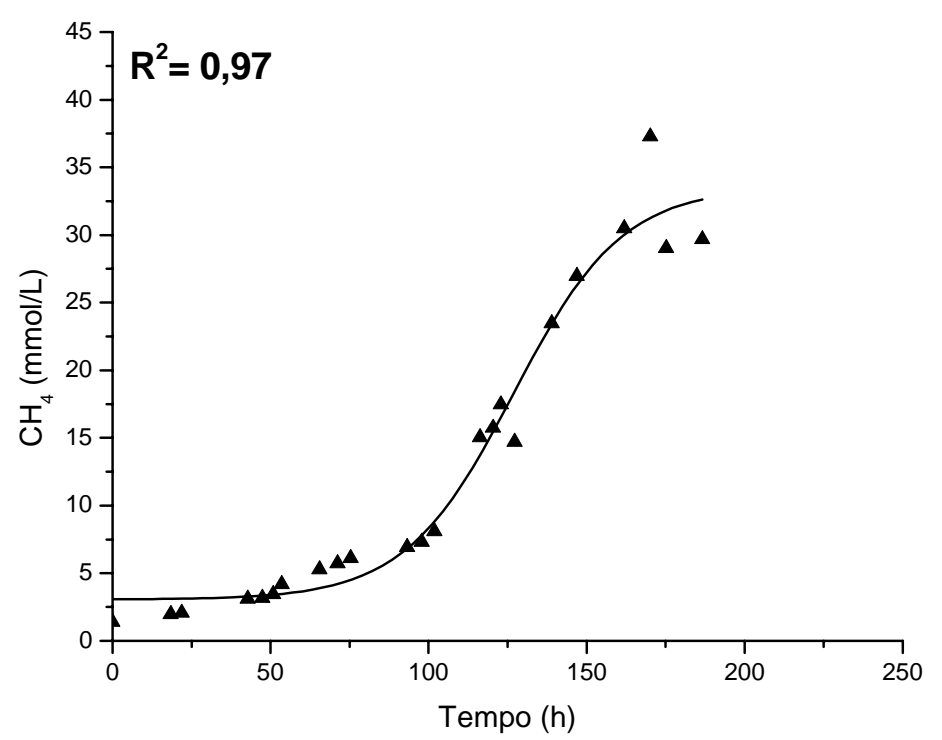

Figura 5.11. Variação temporal da produção de metano ( $\boldsymbol{\Delta}$ - valores experimentais; - modelo sigmoidal ajustado) no reator anaeróbio (1) alimentado com 50mM de metilamina

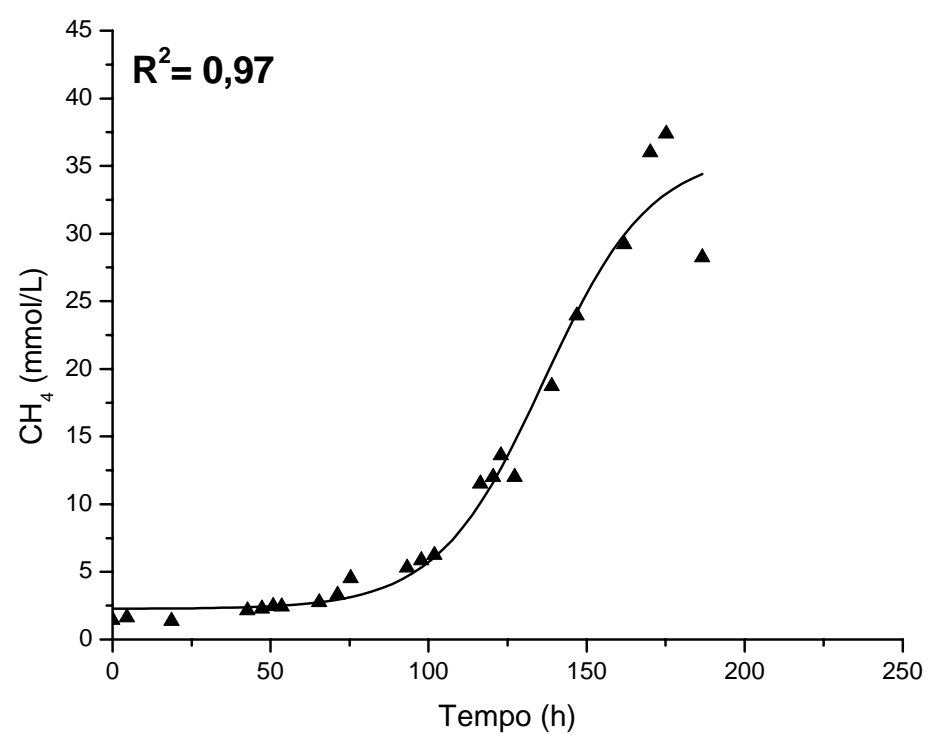

Figura 5.12. Variação temporal da produção de metano ( $\mathbf{\Delta}$ - valores experimentais; - modelo sigmoidal ajustado) no reator anaeróbio (2) alimentado com 50mM de metilamina

A fase lag dos reatores alimentados com $75 \mathrm{mM}$ de metilamina teve duração de 120 horas. Os valores máximos de metano acumulado atingidos após aproximadamente 170 horas de experimento foram de $46,5 \mathrm{mmol} / \mathrm{L}$ no reator (1) e $37,4 \mathrm{mmol} / \mathrm{L}$ no reator (2). Nas Figuras 5.13 e 5.14 está mostrado graficamente a produção de metano nesses reatores. 


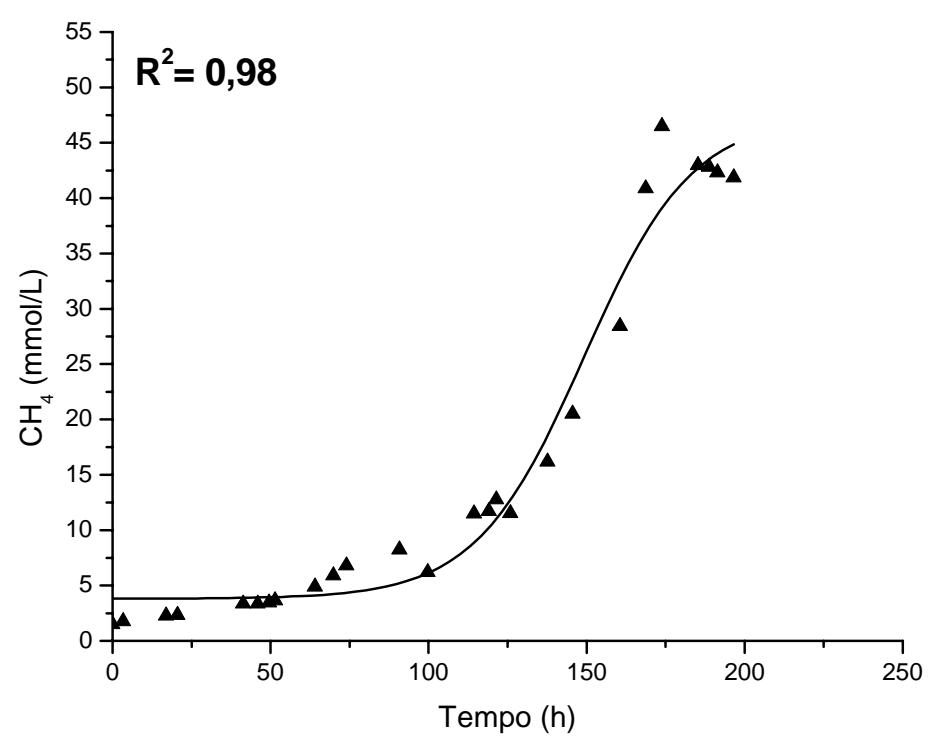

Figura 5.13. Variação temporal da produção de metano ( $\boldsymbol{\Lambda}$ - valores experimentais; - modelo sigmoidal ajustado) no reator anaeróbio (1) alimentado com $75 \mathrm{mM}$ de metilamina

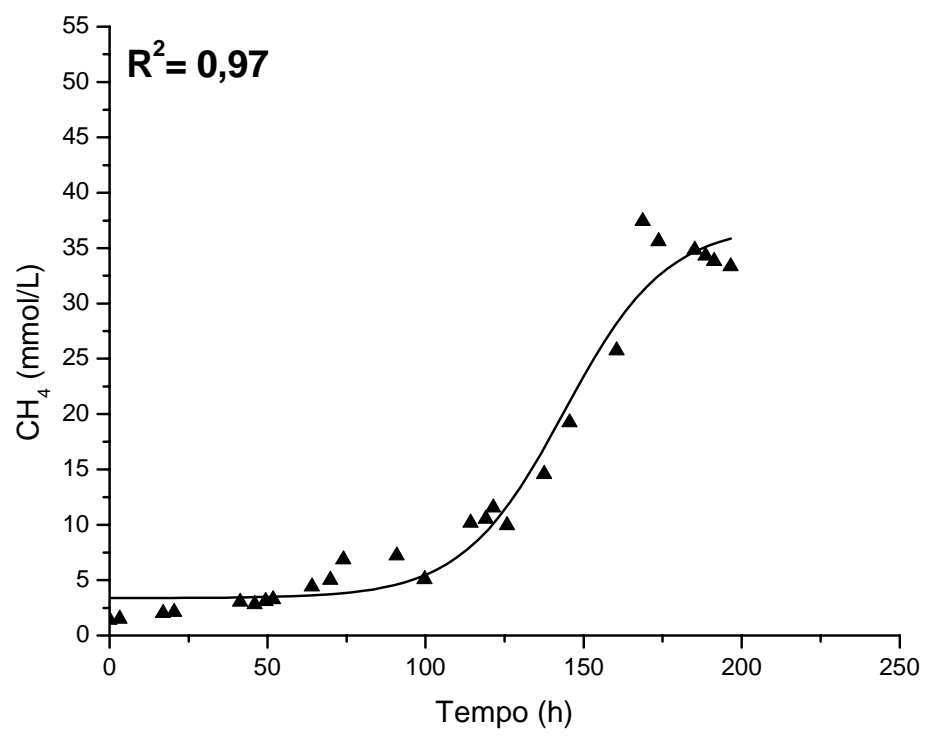

Figura 5.14. Variação temporal da produção de metano ( $\boldsymbol{\Delta}$ - valores experimentais; - modelo sigmoidal ajustado) no reator anaeróbio (2) alimentado com $75 \mathrm{mM}$ de metilamina

Nos reatores alimentados com $90 \mathrm{mM}$ de metilamina a fase lag teve duração aproximada de 125 horas. Os valores máximos de metano acumulado foram obtidos após 170 horas, com valores de 38,6 mmol/L para o reator (1) e 39,6 mmol/L para o reator (2). Nas Figuras 5.15 e 5.16 está mostrado graficamente a produção de metano nesses reatores. 


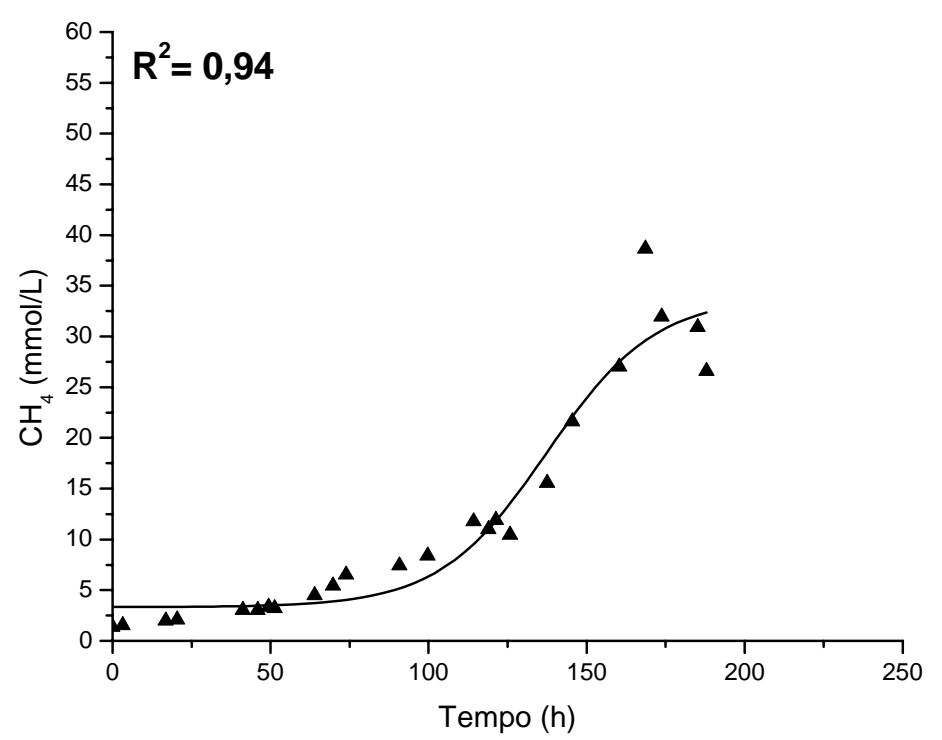

Figura 5.15. Variação temporal da produção de metano ( $\boldsymbol{\Lambda}$ - valores experimentais; - modelo sigmoidal ajustado) no reator anaeróbio (1) alimentado com $90 \mathrm{mM}$ de metilamina

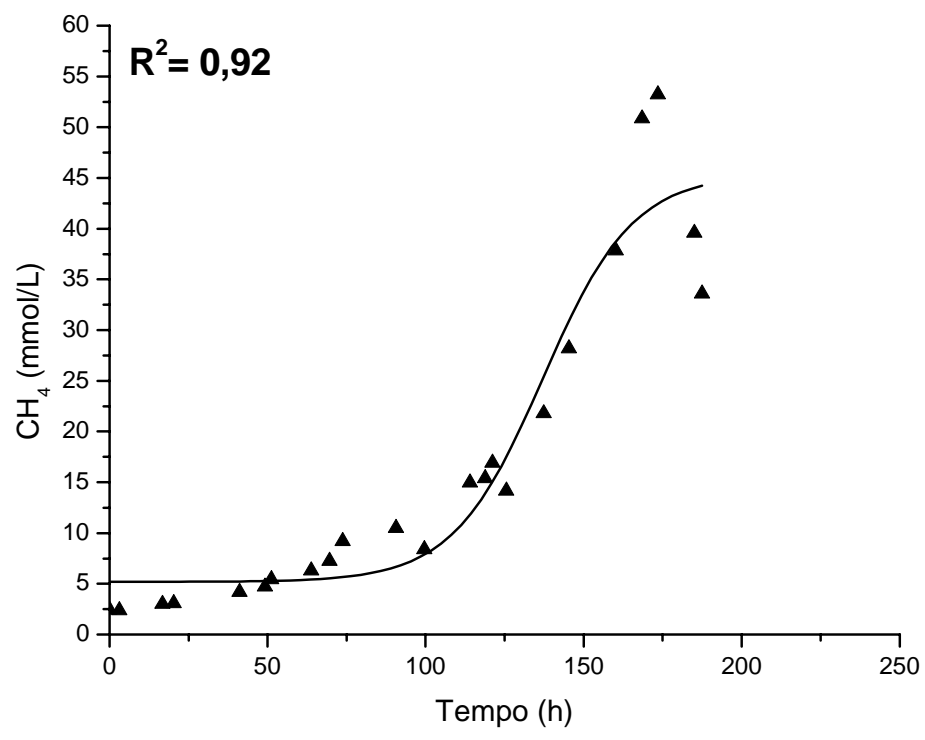

Figura 5.16. Variação temporal da produção de metano ( $\boldsymbol{\Delta}$ - valores experimentais; - modelo sigmoidal ajustado) no reator anaeróbio (2) alimentado com 90mM de metilamina

Os valores de velocidade de formação de metano estão expressos no APÊNDICE 2. O período da fase lag, a produção máxima de metano e a velocidade máxima de formação de metano para cada reator estão expressas na Tabela 5.1. 
Tabela 5.1. Período da fase lag, produção máxima de metano e velocidade máxima de formação de metano em cada reator anaeróbio em batelada

\begin{tabular}{|c|c|c|c|c|}
\hline $\begin{array}{l}\text { Concentração de } \\
\text { Metilamina }\end{array}$ & $\begin{array}{l}\text { Período da } \\
\text { Fase Lag } \\
\text { (h) }\end{array}$ & $\begin{array}{c}\text { Produção } \\
\text { Máxima de } \\
\text { Metano } \\
(\mathrm{mmol} / \mathrm{L})\end{array}$ & $\begin{array}{l}\text { Período da } \\
\text { Produção } \\
\text { Máxima de } \\
\text { Metano (h) }\end{array}$ & $\begin{array}{l}\text { Velocidade Máxima } \\
\text { da Formação de } \\
\text { Metano (mmol/L.h) }\end{array}$ \\
\hline Controle (1) & 0 & 2,57 & 160 & 0,00674 \\
\hline Controle (2) & 0 & 3,25 & 160 & 0,0115 \\
\hline $5 \mathrm{mM}$ - reator $(1)$ & 20 & 6,91 & 116 & 0,0798 \\
\hline $5 \mathrm{mM}$ - reator $(2)$ & 20 & 6,58 & 116 & 0,0913 \\
\hline $10 \mathrm{mM}$ - reator $(1)$ & 20 & 11,8 & 120 & 0,0892 \\
\hline $10 \mathrm{mM}$ - reator $(2)$ & 20 & 9,44 & 120 & 0,0976 \\
\hline $20 \mathrm{mM}$ - reator $(1)$ & 50 & 14,7 & 116 & 0,0174 \\
\hline $20 \mathrm{mM}$ - reator $(2)$ & 50 & 15,3 & 116 & 0,0159 \\
\hline $30 \mathrm{mM}$ - reator $(1)$ & 50 & 20,0 & 122 & 0,346 \\
\hline $30 \mathrm{mM}$ - reator $(2)$ & 50 & 20,4 & 122 & 0,274 \\
\hline $50 \mathrm{mM}$ - reator $(1)$ & 100 & 37,3 & 170 & 0,442 \\
\hline $50 \mathrm{mM}$ - reator $(2)$ & 100 & 37,3 & 175 & 0,500 \\
\hline $75 m M$ - reator $(1)$ & 120 & 46,5 & 170 & 0,635 \\
\hline $75 \mathrm{mM}$ - reator $(2)$ & 120 & 37,4 & 170 & 0,520 \\
\hline $90 \mathrm{mM}$ - reator $(1)$ & 125 & 38,6 & 170 & 0,446 \\
\hline $90 \mathrm{mM}$ - reator (2) & 125 & 39,6 & 170 & 0,453 \\
\hline
\end{tabular}

Nos reatores alimentados com 5mM, 10mM, 20mM e $30 \mathrm{mM}$ de metilamina a fase lag foi menor, porém com baixa produção de metano, com valores em torno de $20 \mathrm{mmol} / \mathrm{L}$. Nos reatores alimentados com 50mM e $75 \mathrm{mM}$ de metilamina obtiveram-se os melhores resultados. Apesar da fase lag mais longa (100h e 120h, respectivamente), a produção de metano foi em torno de $40 \mathrm{mmol} / \mathrm{L}$ e as velocidades máximas de formação de metano foram altas (entre 0,442mmol/L.h e 0,635mmol/L.h). Os reatores (1) e (2) alimentados com 90mM de metilamina, apesar da produção máxima de metano também em torno de 40mmol/L, tiveram decréscimo na velocidade máxima de formação de metano, que ficou em torno de 0,450mmol/L.h.

A velocidade máxima de formação de metano e os valores de sólidos suspensos voláteis foram empregados na determinação da atividade metanogênica específica de cada reator. A determinação dos Sólidos Voláteis Totais (SVT) foi feita para o inóculo e ao final do experimento, para todos os reatores. Os valores obtidos estão apresentados na Tabela 5.2.

A concentração inicial de Sólidos Voláteis Totais (SVT) foi de 5g/L. Os reatores controle, assim como aqueles alimentados com 5mM, 10mM e 20mM de metilamina 
não tiveram aumento significativo no valor de SVT, variando entre 4,2g/L no reator (2) - 20mM e 5,6g/L no reator (1) - 5mM. Para os reatores alimentados com 30mM de metilamina, os valores de SVT foram de 6,2g/L para o reator (1) e 5,1g/L para o reator (2), respectivamente. Os reatores alimentados com $75 \mathrm{mM}$ de metilamina tiveram valor médio de SVT próximo a 7,5g/L. Os maiores valores de SVT foram obtidos para os reatores alimentados com $75 \mathrm{mM}$ e $90 \mathrm{mM}$ de metilamina, variando entre $8,3 \mathrm{~g} / \mathrm{L}(75 \mathrm{mM}$ 2) e 9,5g/L (90mM 1). A Figura 5.17 apresenta graficamente os resultados obtidos para análise dos sólidos voláteis totais, com possíveis variações dos resultados (5\%) atribuídas à precisão do método, descrita no Standard Methods (APPHA, 2005)

Até a concentração de $20 \mathrm{mM}$ de metilamina, o crescimento não foi favorecido, levando à mortalidade celular e à seleção de microrganismos. Todavia, para os reatores alimentados com 30mM, 50mM, 75mM e 90mM de metilamina, ocorreu aumento da biomassa com acréscimo de 13\%, 49\%, 73\% e 81\% respectivamente, para valor inicial de SVT adicionado igual a 5g/L. Esses resultados indicaram que a biomassa foi favorecida com o aumento nas concentrações de metilamina, principalmente em 50mM, $75 \mathrm{mM}$ e $90 \mathrm{mM}$.

Tabela 5.2. Valores de concentração de SVT obtidos nos reatores anaeróbios em batelada

\begin{tabular}{l|c}
\hline Amostras & SVT (g/L) \\
\hline Inoculo & 5,0 \\
Controle 1 & 5,3 \\
Controle 2 & 4,4 \\
$5 \mathrm{mM} 1$ & 5,6 \\
$5 \mathrm{mM} 2$ & 5,0 \\
10mM 1 & 5,3 \\
10mM 2 & 4,3 \\
20mM 1 & 4,3 \\
20mM 2 & 4,2 \\
$30 \mathrm{mM} 1$ & 6,2 \\
30mM 2 & 5,1 \\
$50 \mathrm{mM} 1$ & 7,4 \\
$50 \mathrm{mM} 2$ & 7,5 \\
$75 \mathrm{mM} 1$ & 9,0 \\
$75 \mathrm{mM} 2$ & 8,3 \\
$90 \mathrm{mM} 1$ & 9,5 \\
$90 \mathrm{mM} 2$ & 8,6 \\
\hline
\end{tabular}




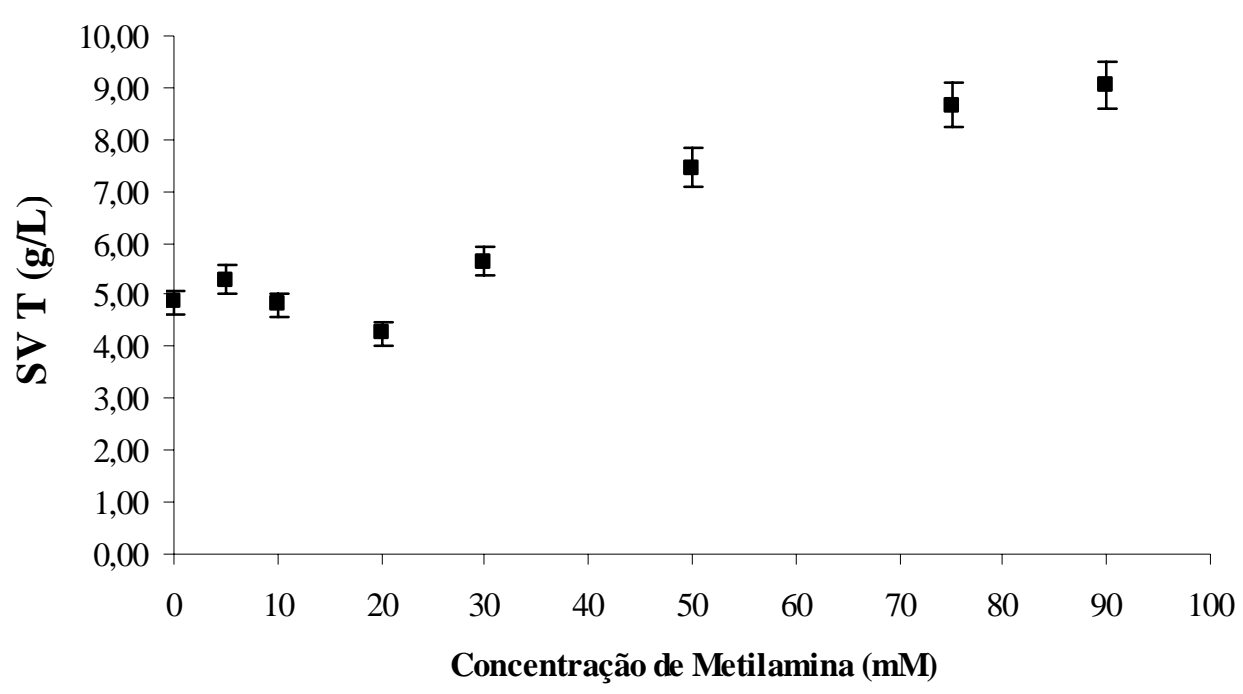

Figura 5.17. Concentração de sólidos voláteis totais para diferentes amostras de reatores anaeróbios alimentados com diferentes concentrações de metilamina (barra de erro de 5\%)

Para determinação da Atividade Metanogênica Aparente (AMA), adotou-se a média entre os Sólidos Voláteis Totais iniciais (inóculo) e os Sólidos Voláteis Totais finais de cada reator. Para cálculo da Atividade Metanogênica Específica (AME), adotou-se a média entre as atividades metanogênicas aparentes dos reatores controles $\mathrm{A}$ e B; esta média foi subtraída dos valores de AMA obtidos em todos os demais reatores. Os valores de AME seguiram tendência de aumento das menores para as maiores concentrações de metilamina. Os valores de AME foram 0,0131 $\mathrm{mmol} \mathrm{CH}_{4} / \mathrm{g} \mathrm{SVT.h} \mathrm{e}$ 0,0163 mmol $\mathrm{CH}_{4} / \mathrm{g}$ SVT.h para o reator (1) e para o reator (2) - 5mM; 0,0153 mmol $\mathrm{CH}_{4} / \mathrm{g}$ SVT.h e 0,0191 $\mathrm{mmol} \mathrm{CH}_{4} / \mathrm{g}$ SVT.h para os reator (1) 2 para o reator (2) 10mM; 0,0355 mmol $\mathrm{CH}_{4} / \mathrm{g}$ SVT.h e 0,0325 mmol $\mathrm{CH}_{4} / \mathrm{g}$ SVT.h para o reator (1) e para o reator (2) - 20mM; 0,0597 $\mathrm{mmol} \mathrm{CH}_{4} / \mathrm{g}$ SVT.h e 0,0577 mmol CH $4 / \mathrm{g}$ SVT.h para o reator (1) e para o reator (2) - 30mM; 0,0828 $\mathrm{mmol} \mathrm{CH}_{4} / \mathrm{g}$ SVT.h e 0,0780 $\mathrm{mmol}$ $\mathrm{CH}_{4} / \mathrm{g}$ SVT.h para o reator (1) e para o reator (2) - 50mM; 0,0887 mmol CH $\mathrm{CH}_{4} / \mathrm{g}$ SVT.h e 0,0763 $\mathrm{mmol} \mathrm{CH}_{4} / \mathrm{g}$ SVT.h para o reator (1) e para o reator (2) - 75mM; 0,0597 mmol $\mathrm{CH}_{4} / \mathrm{g}$ SVT.h e $0,0647 \mathrm{mmol} \mathrm{CH}_{4} / \mathrm{g}$ SVT.h para o reator (1) e para o reator (2) 90mM, respectivamente. Os resultados obtidos estão expressos na Tabela 5.3. 
Tabela 5.3. Valores médios de sólidos voláteis totais, atividade metanogênica aparente (AMA), atividade metanogênica específica (AME)

\begin{tabular}{|c|c|c|c|}
\hline $\begin{array}{c}\text { Reator } \\
\text { anaeróbio em } \\
\text { batelada }\end{array}$ & $\begin{array}{l}\text { Média entre SVT } \\
\text { inicial e final (g/L) }\end{array}$ & $\begin{array}{c}\text { AMA } \\
\text { (mmol CH} 4 / \text { g SVT.h) }\end{array}$ & $\begin{array}{c}\text { AME } \\
\text { (mmol CH } / \text { g SVT.h) }\end{array}$ \\
\hline Controle 1 & 5,15 & 0,00131 & - \\
\hline Controle 2 & 4,68 & 0,00245 & - \\
\hline $5 \mathrm{mM} 1$ & 5,31 & 0,0150 & 0,0131 \\
\hline $5 \mathrm{mM} 2$ & 5,01 & 0,0182 & 0,0163 \\
\hline $10 \mathrm{mM} 1$ & 5,17 & 0,0173 & 0,0153 \\
\hline 10 mM 2 & 4,65 & 0,0209 & 0,0191 \\
\hline $20 \mathrm{mM} 1$ & 4,65 & 0,0374 & 0,0355 \\
\hline 20 mM 2 & 4,60 & 0,0344 & 0,0325 \\
\hline $30 \mathrm{mM} 1$ & 5,61 & 0,0616 & 0,0597 \\
\hline $30 \mathrm{mM} 2$ & 5,07 & 0,0596 & 0,0577 \\
\hline $50 \mathrm{mM} 1$ & 5,22 & 0,0847 & 0,0828 \\
\hline $50 \mathrm{mM} 2$ & 6,26 & 0,0799 & 0,0780 \\
\hline 75 mM 1 & 7,01 & 0,0906 & 0,0887 \\
\hline 75 mM 2 & 6,65 & 0,0689 & 0,0763 \\
\hline $90 \mathrm{mM} 1$ & 7,24 & 0,0616 & 0,0597 \\
\hline $90 \mathrm{mM} 2$ & 6,80 & 0,0666 & 0,0647 \\
\hline
\end{tabular}

OLIVEIRA (1997) comparou a AME de lodo mesofílico granular bruto e lavado, constatando o aumento da AME para o lodo lavado. O autor atribuiu esse resultado à retirada dos sólidos finos pela lavagem. A atividade metanogênica aparente do frasco controle inoculado com lodo bruto foi atribuída à presença de substratos facilmente degradáveis disponíveis para a metanogênese.

Neste trabalho, buscou-se minimizar interferências na determinação da AME para reatores alimentados com metilamina submetendo o lodo à lavagem e ao esgotamento prévio de matéria orgânica já existente por período de 15 dias.

STEIL (2001) determinou a AME para o efluente de biodigestor em batelada tratando resíduos de aves de postura, frangos de corte e suínos, usando conjuntamente os substratos acetato, propionato, butirato e formiato de sódio em cargas orgânicas que variaram de 0,25 g DQO/g SV, 0,50 g DQO/g SV, 0,75 g DQO/g SV e 1,00 g DQO/g SV. O inóculo correspondeu a $10 \%$ do substrato. Os valores médios de AME encontrados, para aves de postura, foram de 0,1984 $\mathrm{mmol} \mathrm{CH}_{4} / \mathrm{g}$ SVT, 0,1901 $\mathrm{mmol}$

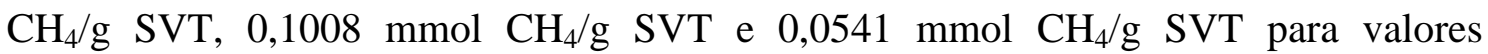
crescentes de carga orgânica, respectivamente. Para frangos de corte, os valores foram 0,2109 $\mathrm{mmol} \mathrm{CH}_{4} / \mathrm{g}$ SVT, 0,0973 $\mathrm{mmol} \mathrm{CH}_{4} / \mathrm{g} \mathrm{SVT,} \mathrm{0,0558} \mathrm{mmol} \mathrm{CH}_{4} / \mathrm{g} \mathrm{SVT} \mathrm{e} \mathrm{0,0372}$ mmol $\mathrm{CH}_{4} / \mathrm{g}$ SVT; para suínos, os valores foram 0,2532 mmol $\mathrm{CH}_{4} / \mathrm{g} \mathrm{SVT}$, 0,0941 mmol $\mathrm{CH}_{4} / \mathrm{g}$ SVT, $0,0542 \mathrm{mmol} \mathrm{CH}_{4} / \mathrm{g}$ SVT e 0,1105 $\mathrm{mmol} \mathrm{CH}_{4} / \mathrm{g}$ SVT, respectivamente. 
No presente trabalho, os valores de AMA ficaram em 0,00131 $\mathrm{mmol} \mathrm{CH}_{4} / \mathrm{g}$ SVT.h e 0,00245 $\mathrm{mmol} \mathrm{CH}_{4} / \mathrm{g}$ SVT.h para os reatores Controle (1) e (2), e variaram entre 0,0131 e 0,0887 para os reatores acrescidos de fonte de carbono (metilamina). Como os frascos reatores foram inoculados com lodo de mesma origem, e foram submetidos às mesmas condições de análise, pode-se concluir que o aumento da AME foi devido à maior disponibilidade de fontes orgânicas no substrato. Isso poderia explicar o crescente aumento da AME de acordo com o aumento das concentrações de metilamina disponibilizadas.

O modelo cinético de Monod foi ajustado aos valores da AME compreendidos entre $0 \mathrm{mM}$ e 75mM (Figura 5.18). A Atividade Metanogênica Específica Máxima foi determinada em 0,15 mmol $\mathrm{CH}_{4} / \mathrm{g}$ SVT.h. Os reatores com concentração de $90 \mathrm{mM}$, que apresentaram valores de atividade metanogênica inferiores aos de concentrações 50mM e 75mM, não foram ajustados ao modelo cinético.

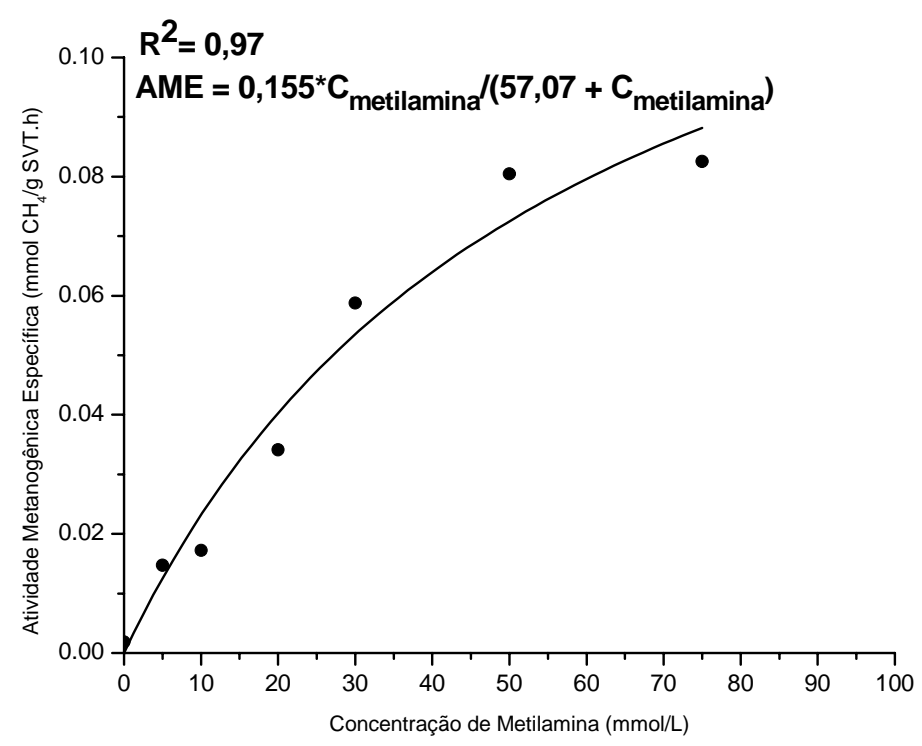

Figura 5.18. Ajuste do modelo cinético de Monod

Os valores obtidos no teste de atividade metanogênica mostram provável inibição de produção de metano nos reatores de concentração 90mM. Esta inibição pode ser atribuída a possível erro experimental ou ao excesso de substrato.

As concentrações de $\mathrm{N}$ amoniacal foram determinadas no início e final do experimento. A produção aumentou de acordo com as concentrações de metilamina adotadas, com exceção do reator 90mM que teve decréscimo de produção comparado ao 
reator de concentração 75mM. Os reatores controle tiveram valores finais de $202 \mathrm{mg} / \mathrm{L}$ N AMONIACALapós 9 dias decorridos do início do experimento, quando a atividade metanogênica já estava estável em todos os reatores. Os valores de nitrogênio amoniacal finais médios para os reatores de diferentes concentrações foram, respectivamente: 144 mg/L $\mathrm{N}$ amoniacal (5 mM de metilamina); $197 \mathrm{mg} / \mathrm{L} \mathrm{N}$ amoniacal (10 mM de metilamina); $441 \mathrm{mg} / \mathrm{L} \mathrm{N}$ amoniacal (20 mM de metilamina); 566 mg/L N amoniacal (30 mM de metilamina); $828 \mathrm{mg} / \mathrm{L} \mathrm{N}$ amoniacal (50 mM de metilamina); $1070 \mathrm{mg} / \mathrm{L} \mathrm{N}$ amoniacal (75 mM de metilamina); 1006 mg/L N amoniacal (90 mM de metilamina) A comparação entre todas as concentrações está apresentada na Figura 5.19.

Determinou-se, também, a porcentagem de conversão do $\mathrm{N}$ presente na molécula de metilamina a $\mathrm{N}$ amoniacal. Para as menores concentrações (5 mM e $10 \mathrm{mM}$ de metilamina), as moléculas de $\mathrm{N}$ amoniacal geradas foram usadas no metabolismo celular dos microrganismos (assimilação), e não se acumularam no meio. Reatores alimentados com metilamina em concentrações $20 \mathrm{mM}, 30 \mathrm{mM}$ e $50 \mathrm{mM}$ apresentaram quase $100 \%$ de formação de $\mathrm{N}$ amoniacal a partir da amina presente na molécula de metilamina (99,3\% no reator 20mM, 95,9\% no reator 30mM e 95,9\% no reator 50mM). Os reatores com metilamina em concentração $75 \mathrm{mM}$ e $90 \mathrm{mM}$ apresentaram certa inibição na formação de $\mathrm{N}$ amoniacal (86,4\% no reator $75 \mathrm{mM}$ e $66,9 \%$ no reator 90mM).

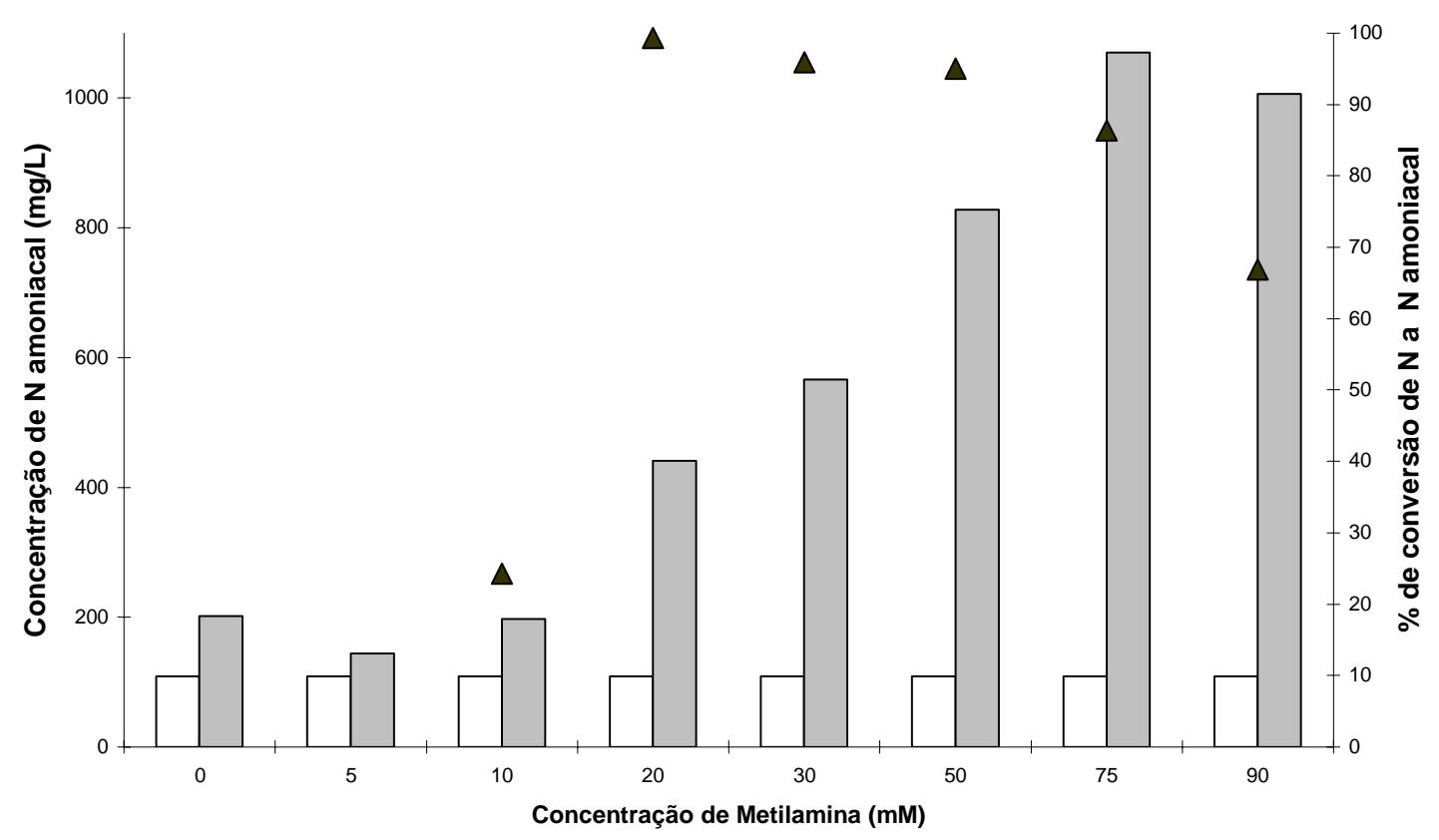

Figura 5.19. Concentrações de $\mathrm{N}$ amoniacal no início e final do experimento e porcentagem de conversão de $\mathrm{N}$ orgânico a $\mathrm{N}$ amoniacal 
A técnica de Número Mais Provável (NMP) foi realizada com tempo de incubação de 15 dias. Para microrganismos mesofílicos, o tempo de incubação geralmente adotado é de 30 dias. Nesse experimento, o tempo de incubação adotado foi ajustado à atividade metanogênica dos reatores alimentados com solução de metilamina, que mostraram sua eficiência máxima em apenas 11 dias. Os resultados da técnica estão expressos na Tabela 5.4 e na Figura 5.20.

Os resultados da técnica de NMP mostraram uma tendência de aumento do $\mathrm{NMP} / \mathrm{mL}$ de microrganismos anaeróbios de acordo com o aumento da concentração de metilamina. As bactérias anaeróbias totais e as arquéias metanogênicas foram encontradas em quantidades de mesma ordem de grandeza. Isto indicou que quase a totalidade de microrganismos anaeróbios presentes eram representados por microrganismos pertencentes ao Domínio Archaea.

Tabela 5.4. Número Mais Provável (NMP) para bactérias anaeróbias totais e arquéias metanogênicas

\begin{tabular}{c|c|c}
\hline \multirow{2}{*}{$\begin{array}{c}\text { Concentração } \\
\text { de metilamina }\end{array}$} & \multicolumn{2}{|c}{$\mathbf{N M P} / \mathbf{m L}$} \\
\cline { 2 - 3 } Controle & Bactérias Anaeróbios Totais & Arquéias metanogênicas \\
$\mathbf{5 m M}$ & $2,3 \times 10^{1}$ & 0 \\
$\mathbf{1 0} \mathbf{m M}$ & $1,4 \times 10^{4}$ & $1,3 \times 10^{3}$ \\
$\mathbf{2 0} \mathbf{m M}$ & $1,1 \times 10^{4}$ & $3,0 \times 10^{4}$ \\
$\mathbf{3 0 m M}$ & $7,0 \times 10^{4}$ & $5,0 \times 10^{4}$ \\
$\mathbf{5 0 m M}$ & $7,0 \times 10^{4}$ & $1,3 \times 10^{6}$ \\
$\mathbf{7 5 m M}$ & $7,0 \times 10^{4}$ & $4,0 \times 10^{5}$ \\
$\mathbf{9 0 m M}$ & $1,1 \times 10^{8}$ & $4.0 \times 10^{7}$ \\
\hline
\end{tabular}




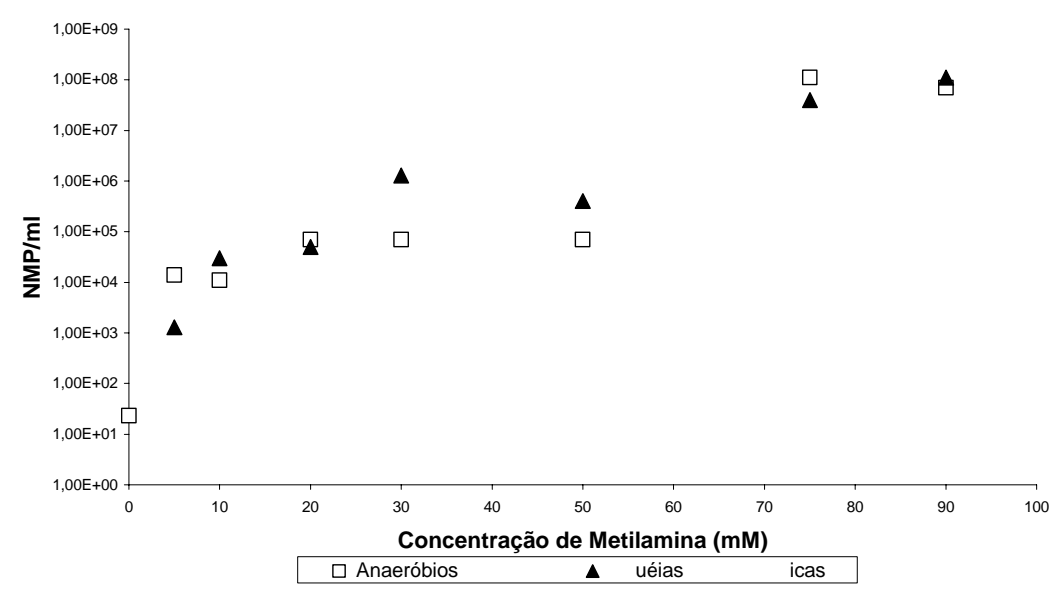

Figura 5.20. Número Mais Provável $(\mathrm{NMP} / \mathrm{mL})$ de bactérias anaeróbias totais e arquéias metanogênicas

ALVAREZ et al. (2000), estudaram a colonização de água residuária de indústria pesqueira por microrganismos metanogênicos e sulfetogênicos em filtro anaeróbio. Encontraram a estimativa NMP para metanogênicas da ordem de $10^{8}$, semelhante à observada neste estudo para as maiores concentrações de metilamina. A fonte de carbono usada foi metilamina em concentração não exposta no trabalho.

As análises de ácidos orgânicos voláteis detectaram pequenas quantidades de ácido acético no início do experimento. Ao final, todos os ácidos foram encontrados em quantidades traço. As concentrações de ácido acético presentes nos reatores foram: 8,7 mg/L (controle - sem metilamina), 8,1 mg/L (5mM), 8,2 mg/L (10mM), 7,1 mg/L (20mM), 6,8 mg/L (30mM), 7,8 mg/L (50mM), 7,2 mg/L (75mM) e 4,0 mg/L (90mM).

Os exames microscópicos realizados mostraram semelhança de morfologias microbianas para os reatores anaeróbios alimentados com as diferentes concentrações de metilamina. Em relação ao Domínio Archaea, foram encontrados Methanosarcina sp., Methanosaeta sp e formas encistadas. Algumas arquéias metanogênicas, notadamente Methanosarcina sp. e Methanosaeta sp., têm suas morfologias distintas e podem ser identificadas em amostras naturais usando microscopia de contraste de fase e fluorescência, principalmente para Methanosarcina sp. (ZINDER, 1993).

Methanosarcina sp. caracteriza-se pela disposição cúbica dos cocos formando sarcinas e pela fluorescência típica resultante da presença da coenzima $\mathrm{F}_{420}$. Esta coenzima interage com diferentes enzimas durante a metanogênese, incluindo hidrogenase e $\mathrm{NADP}^{+}$reductase. A coenzima $\mathrm{F}_{420}$ também age como doadora de elétrons em pelo menos uma etapa da redução do $\mathrm{CO}_{2}$. A forma oxidada da coenzima 
$\mathrm{F}_{420}$ absorve luz em $420 \mathrm{~nm}$ e fluoresce com coloração azulada. Na forma reduzida, $\mathrm{F}_{420}$ torna-se incolor (MADIGAN et al., 1997).

Methanosaeta sp. é caracterizada por bacilos de extremidade reta, que formam filamentos longos e flexíveis. Nas células de Methanosaeta sp., a coenzima $\mathrm{F}_{420}$ é encontrada em concentrações baixas que não causam auto fluorescência visível sob microscopia com ultra violeta (KONIG et al., 1989).

A presença de Methanosarcina sp. explica-se pelo fato dessas arquéias usarem metilamina como substrato para produção de metano, pela via metilotrófica. A presença de Methanosaeta sp., que utiliza via acetoclástica de degradação, explica-se pela presença do ácido acético no lodo, mesmo em baixas concentrações.

O Domínio Bacteria foi representado por bacilos, cocos, coco-bacilos e filamentos. Aglomerados de bacilos estavam presentes em todos os reatores. Cocos foram raramente observados. Bacilos delgados, coco-bacilos e filamentos foram as morfologias predominantes em todas as concentrações de metilamina. A freqüência dos grupos de microrganismo nos reatores anaeróbios em batelada pode ser comparada nas Tabelas 5.5 e 5.6. As Figuras 5.22, 5.23 e 5.24 mostram as diferentes morfologias encontradas.

DEL NERY et al. (2002) estudaram a diversidade microbiana em grânulos oriundos de reator UASB usado no tratamento de água residuária de abatedouro de aves. A técnica de Hibridação In Situ com Sondas Fluorescentes (FISH) foi empregada, com uso de sondas para o Domínio Bacteria (EUB338), Domínio Archaea (ARC915) e para células de Methanosaeta (MX825), Methanosarcina (MS821) e Methanobacteriaceae (MB1174). Os resultados mostraram predomínio de células do Domínio Archaea na composição do grânulo. As arquéias metanogênicas representaram entre 77,7\% $( \pm 2,7)$ e 85,4\% $( \pm 1,5)$ da composição microbiana dos grânulos. Entre as células do Domínio Archaea, Methanosaeta, Methanosarcina e Methanobacteriaceae apareceram em todos os grânulos. Sendo assim, a escolha desse lodo como inóculo favoreceu a degradação anaeróbia da metilamina, por se tratar de biomassa essencialmente metanogênica.

Na comparação dos padrões de bandas de DGGE, utilizou-se a equação de GILLIAN et al. (1998), que calcula o coeficiente de similaridade entre duas amostras. A intensidade das bandas de DGGE não foi considerada fator variável. O coeficiente de similaridade, para Bacteria, variou entre 92\% (na comparação do inóculo com as diferentes concentrações de metilamina) e 100\% (na comparação entre as diferentes concentrações de metilamina) Aparentemente a diversidade microbiana com relação ao 
Domínio Bacteria visualizada pelas bandas do DGGE mantiveram-se constantes para todas a condições estudadas, inclusive para os controles.

As bandas de DGGE para o Domínio Bacteria estão representadas na Figura 5.21 pelas letras de A a G. Praticamente não houve variação no padrão de bandas entre as amostras de diferentes concentrações de metilamina. A população indicada pela banda B foi favorecida em todas as concentrações. As populações representadas pelas bandas $\mathrm{A}$ e $\mathrm{C}$ foram as mais sensíveis às alterações na composição do meio, pois foram encontradas somente no inóculo. As populações representadas pelas bandas B, D, E, F e $\mathrm{G}$ parecem ter sido favorecidas pelas condições do sistema.

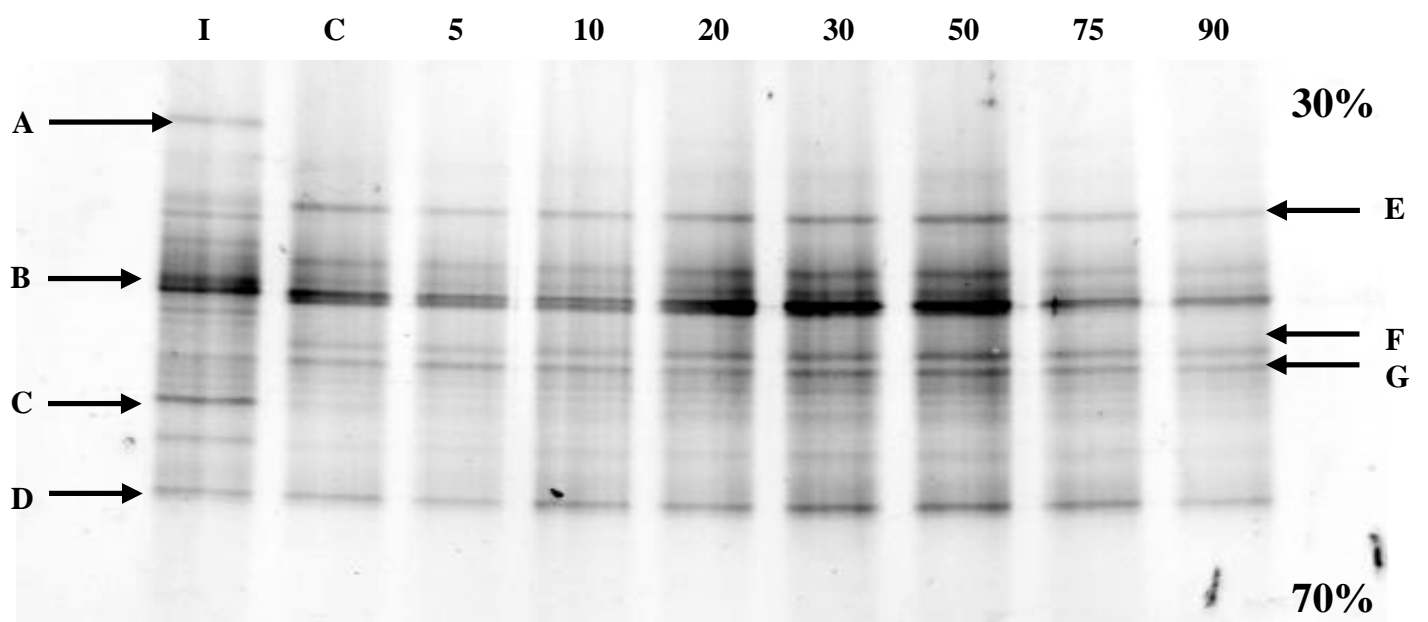

Figura 5.21. Resultados das análises de DGGE dos fragmentos dos produtos de PCR amplificados com primers do Domínio Bacteria para as amostras: I-inóculo, C-controle (sem metilamina), 5 ( $5 \mathrm{mM}$ de metilamina), 10 (10 $\mathrm{mM}$ de metilamina), 20 (20mM de metilamina), 30 (30mM de metilamina), 50 (50mM de metilamina), 75 ( $75 \mathrm{mM}$ de metilamina) e 90 (90mM de metilamina)

O coeficiente de similaridade, para o Domínios Archaea, também variou entre 92\% (na comparação entre o inóculo e as diferentes concentrações de metilamina) e 100\% (na comparação entre as diferentes concentrações de metilamina).

Aparentemente a diversidade microbiana com relação ao Domínio Archaea visualizada pelas bandas do DGGE manteve-se constante para todas as condições estudadas. 
Tabela 5.5. Frequência de microrganismos pertencentes ao Domínio Archaea nos reatores alimentados com metilamina

\begin{tabular}{l|c|c|c|c|c|c|c|c|c}
\hline \hline \multicolumn{10}{c}{ Arquéias Metanogênicas } \\
\hline \hline MORFOLOGIA & Inóculo & Controle & $\mathbf{5 ~} \mathbf{~ M M}$ & $\mathbf{1 0} \mathbf{~ m M}$ & $\mathbf{2 0} \mathbf{~ m M}$ & $\mathbf{3 0} \mathbf{~ m M}$ & $\mathbf{5 0} \mathbf{~ m M}$ & $\mathbf{7 5} \mathbf{~ m M}$ & $\mathbf{9 0} \mathbf{~ m M}$ \\
\hline Methanosarcina sp. & + & + & + & ++ & ++ & +++ & ++++ & ++++ & ++++ \\
\hline Methanosaeta sp. & + & + & + & + & ++ & +++ & +++ & +++ & +++ \\
\hline Cistos de sarcinas & + & + & + & ++ & +++ & +++ & ++ & ++ & ++ \\
\hline \hline
\end{tabular}

$(++++)$ predominantes, $(+++)$ freqüentes, $(++)$ pouco freqüentes, $(+)$ raros, $(-)$ não foram observados

Tabela 5.6. Frequência de microrganismos pertencentes ao Domínio Bacteria nos reatores alimentados com metilamina

\begin{tabular}{|c|c|c|c|c|c|c|c|c|c|}
\hline \multicolumn{10}{|c|}{ Bactérias } \\
\hline MORFOLOGIA & Inóculo & Controle & $5 \mathrm{mM}$ & $10 \mathrm{mM}$ & $20 \mathrm{mM}$ & $30 \mathrm{mM}$ & $50 \mathrm{mM}$ & $75 \mathrm{mM}$ & $90 \mathrm{mM}$ \\
\hline Cocos & + & + & + & + & + & + & + & + & + \\
\hline Bacilos & +++ & +++ & +++ & +++ & ++++ & ++++ & ++++ & ++++ & ++++ \\
\hline Bacilos curvos & - & - & ++ & ++ & ++ & ++ & ++ & ++ & ++ \\
\hline Bacilos delgados & ++++ & ++++ & ++++ & ++++ & ++++ & ++++ & ++++ & ++++ & ++++ \\
\hline Cocos-bacilos & +++ & +++ & +++ & +++ & ++++ & ++++ & ++++ & ++++ & ++++ \\
\hline Filamentos & - & - & - & ++ & ++ & ++ & ++ & ++ & ++ \\
\hline
\end{tabular}

$(++++)$ predominantes, $(+++)$ freqüentes, $(++)$ pouco freqüentes, $(+)$ raros, $(-)$ não foram observados 


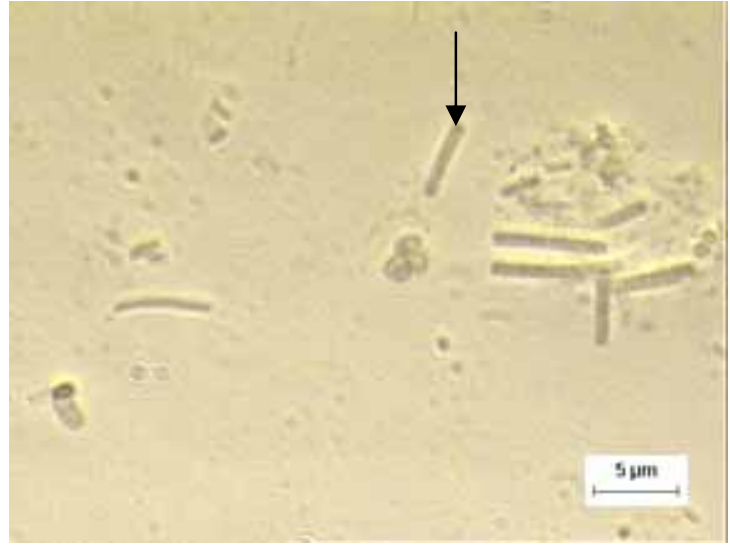

(a)

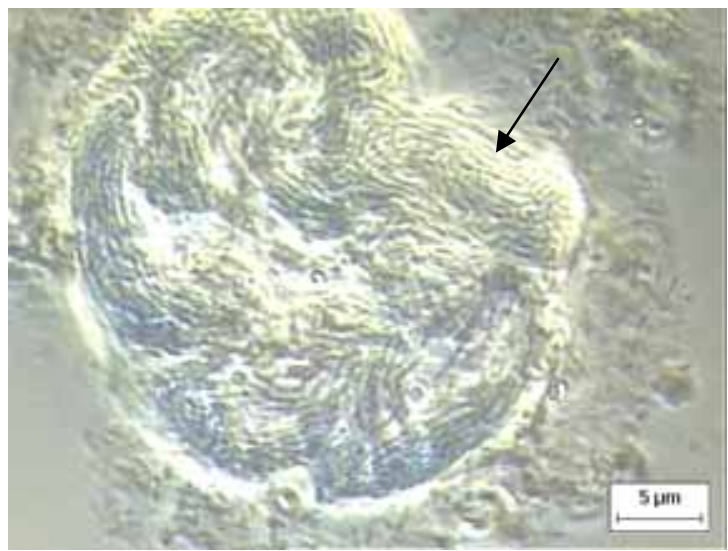

(c)

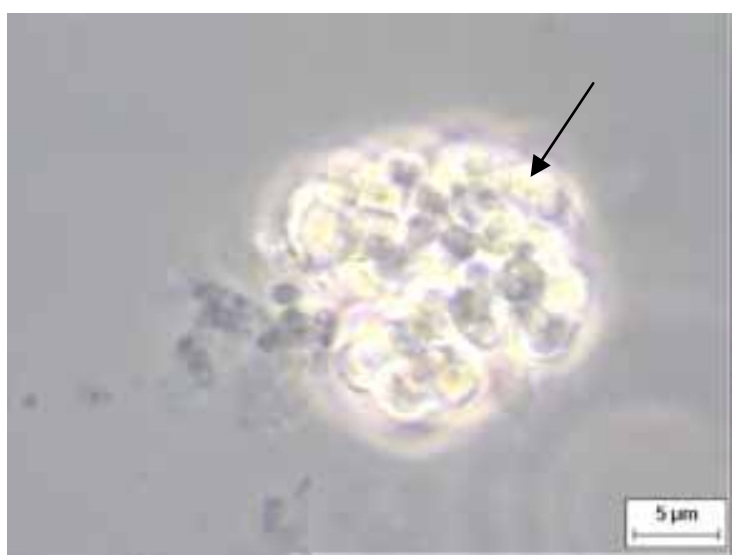

(e)

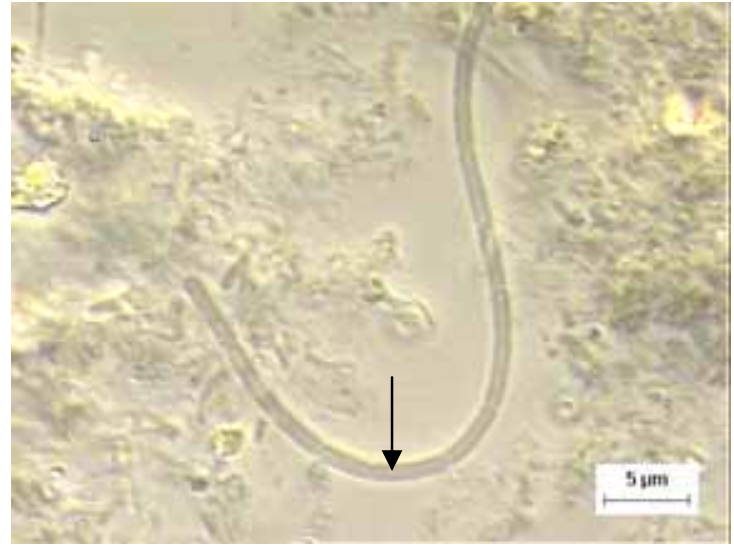

(b)

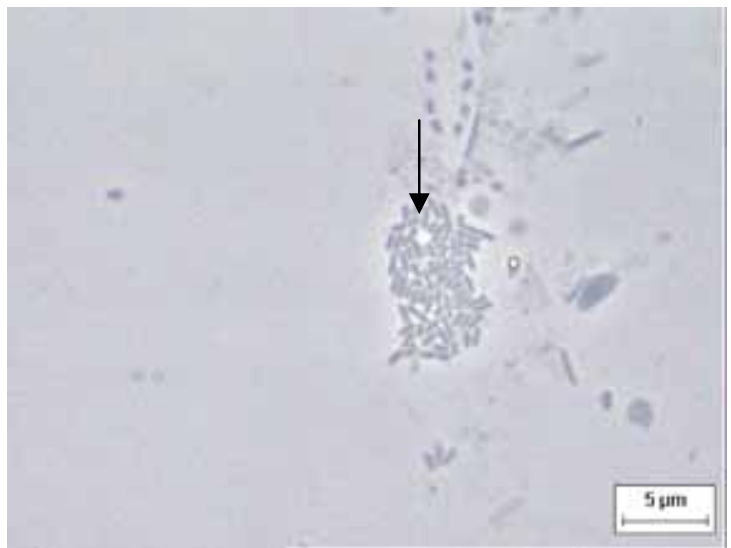

(d)

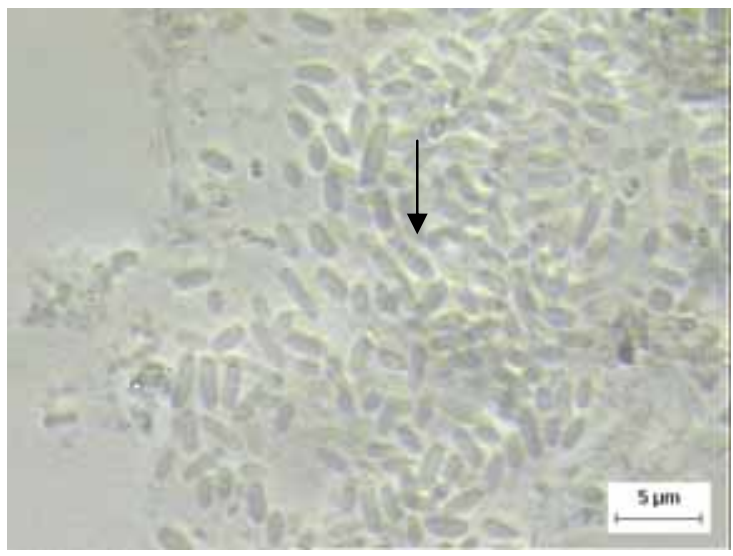

(f)

Figura 5.22. Microscopia de contraste de fase de amostras dos reatores anaeróbios em batelada: a- Methanosaeta sp. (Controle - sem metilamina); b- Filamento (5mM de metilamina); cAglomerado de bacilos (5mM de metilamina); d- Bacilos (10mM de metilamina); eMethanosarcina sp. (10 mM de metilamina); f- Bacilos (20mM de metilamina) 


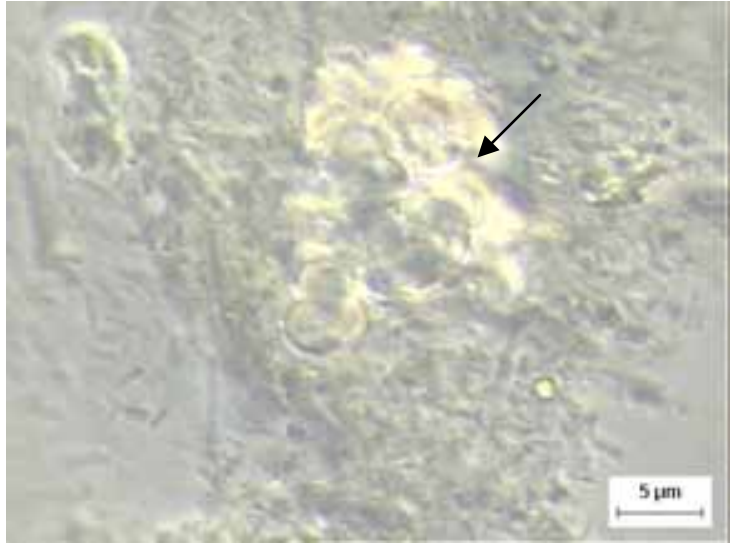

(a)

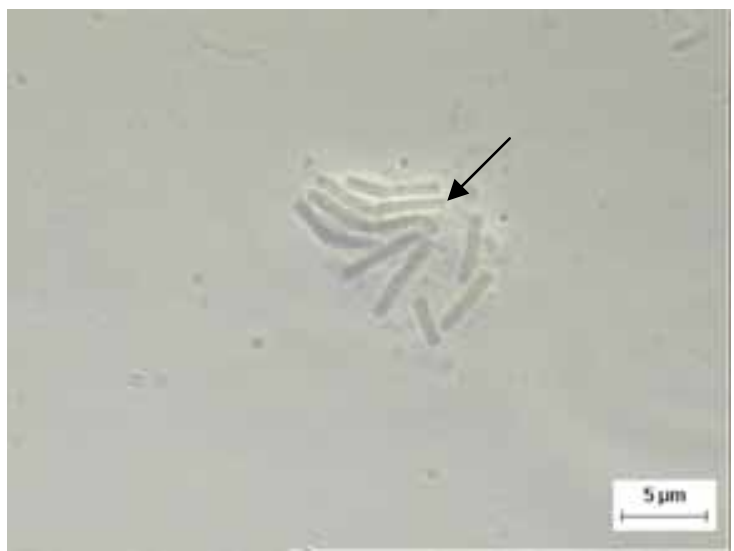

(c)

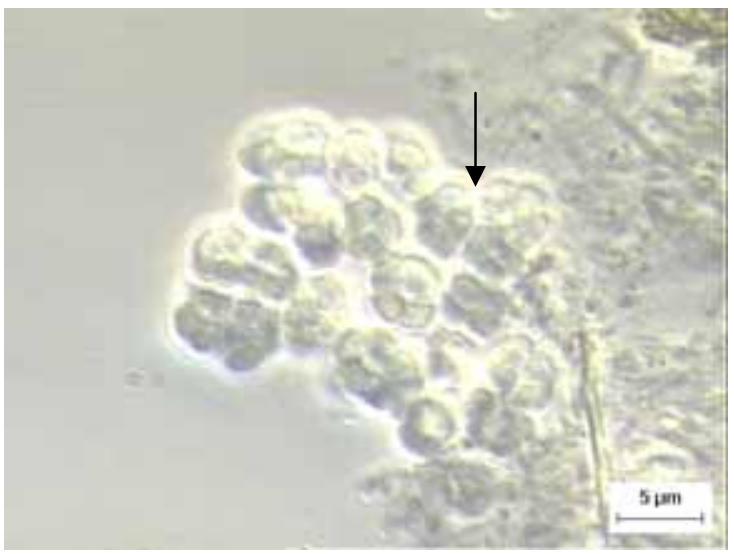

(e)

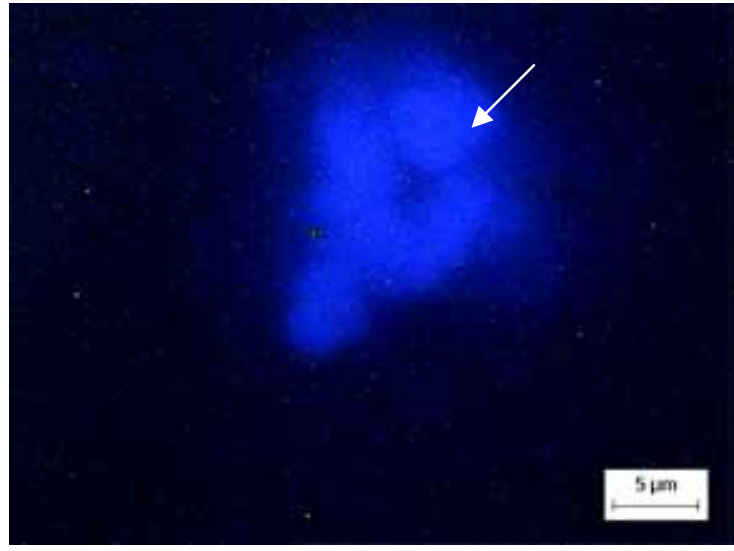

(b)

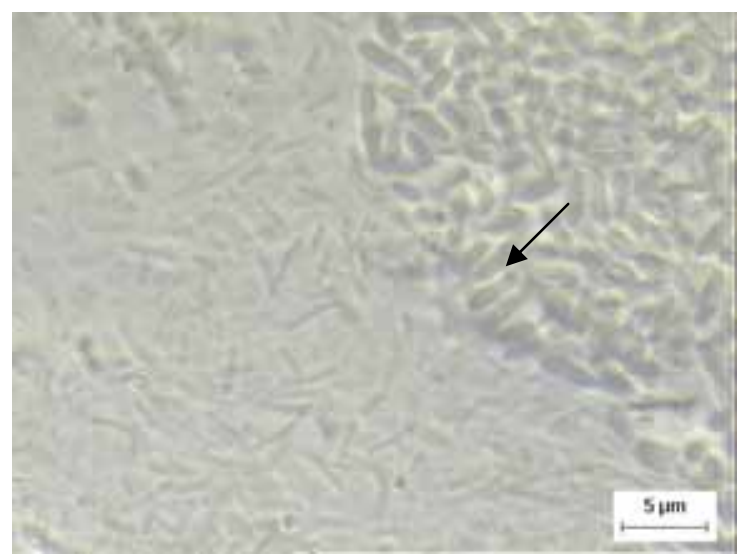

(d)

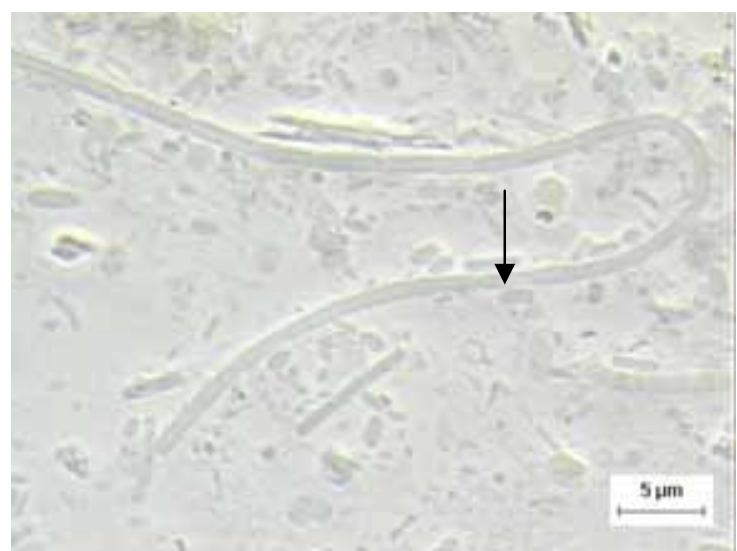

(f)

Figura 5.23. Microscopia de contraste de fase e fluorescência de amostras dos reatores anaeróbios em batelada: a- Methanosarcina sp. (30mM de metilamina), b- Methanosarcina sp. (fluorescência - 30mMB de metilamina); c- Methanosaeta sp. (50mM de metilamina); dBacilos (30mM de metilamina); e- Methanosarcina sp. (50mM de metilamina); f- Filamento (50mM de metilamina) 


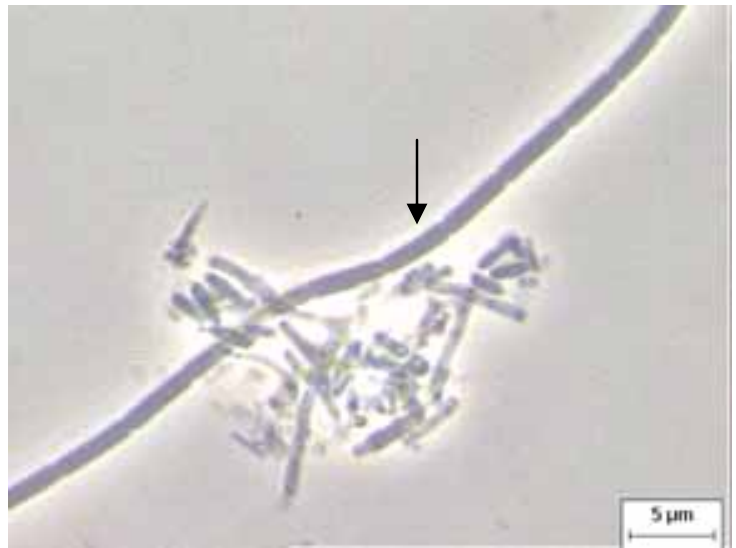

(a)

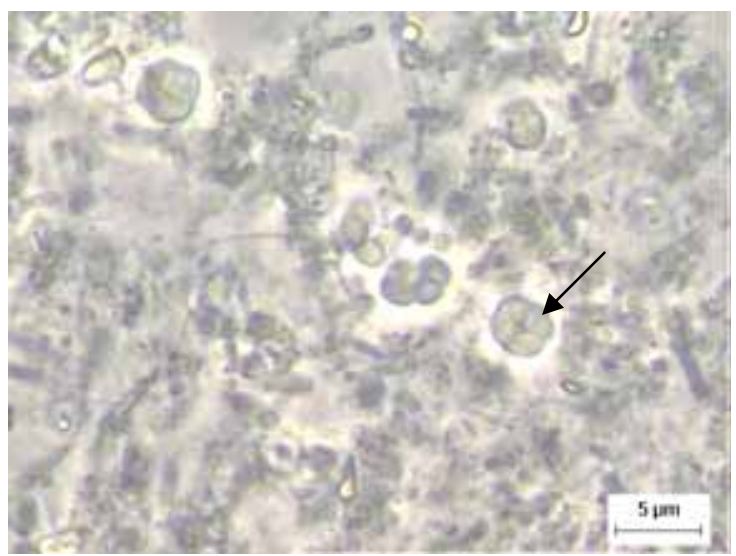

(c)

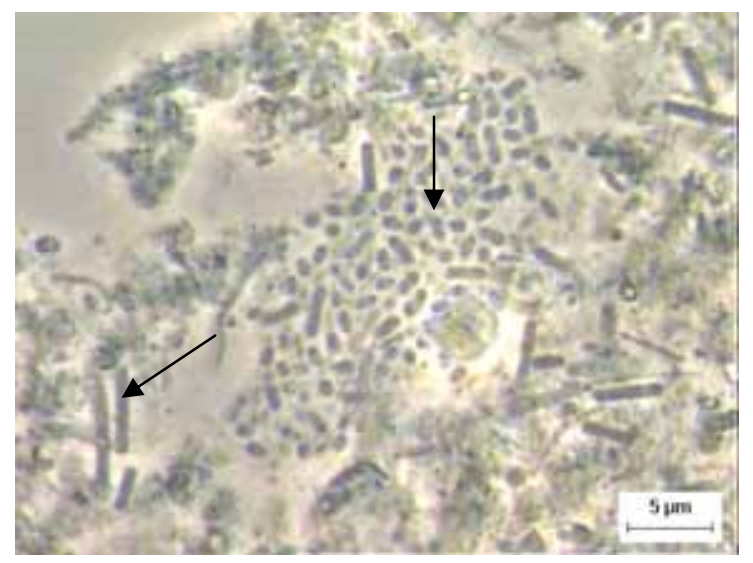

(e)

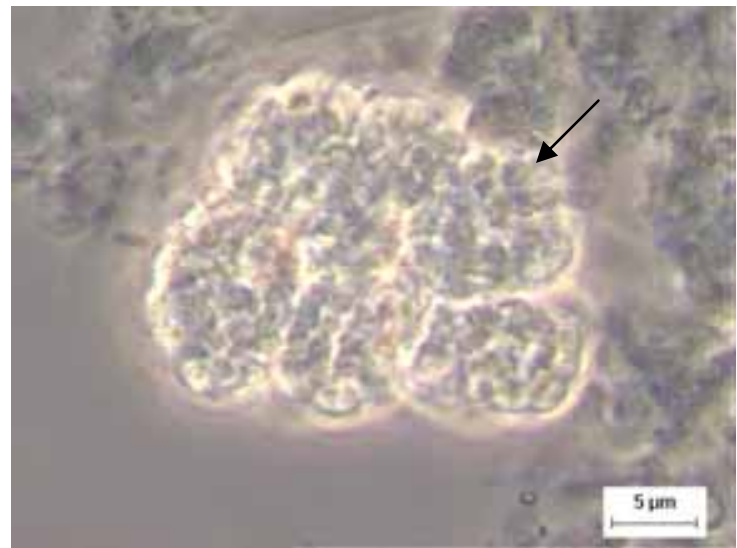

(b)

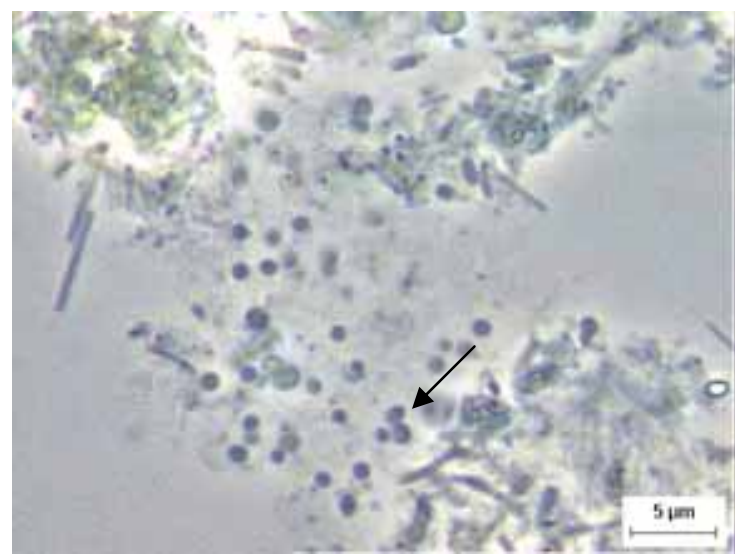

(d)

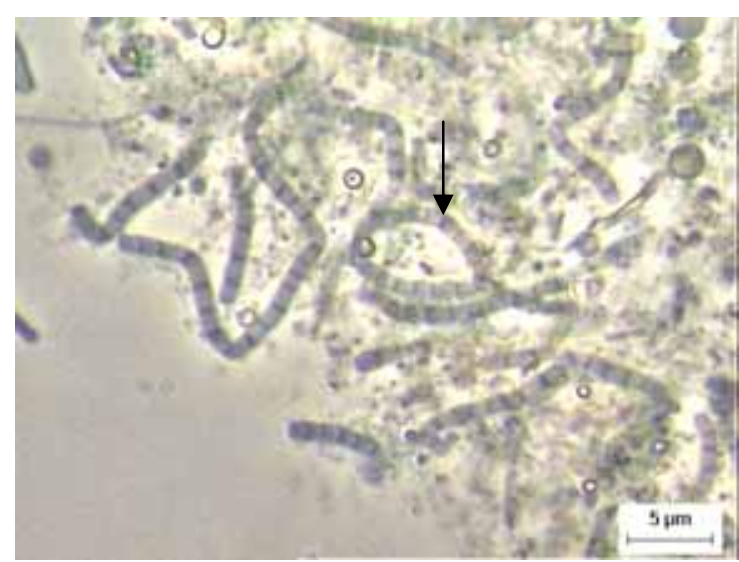

(f)

Figura 5.24. Microscopia de contraste de fase de amostras dos reatores anaeróbios em batelada: a- Methanosaeta sp. (50mM de metilamina), b- Methanosarcina sp. (50mM de metilamina); cMethanosarcina sp. (75mM de metilamina), d- Cocos (75mM de metilamina); e- Coco-bacilos, bacilos e Methanosaeta sp. (90mM de metilamina); f- Filamentos (90mM de metilamina) 
As populações do Domínio Archaea, representadas pelas bandas de DGGE, estão indicadas na Figura 5.25 pelas letras de A a H. Não houve variação no padrão de bandas entre as amostras de diferentes concentrações de metilamina. A banda $\mathrm{H}$ parece representar a única população de arquéia metanogênica favorecida pelo aumento nas concentrações de metilamina, e a banda A representa a população microbiana mais favorecida em todas elas. As bandas B, C, D, E, F e G parecem ter sido favorecidas em todas as concentrações de metilamina.

A banda A presente no gel de DGGE do Domínio Archaea foi seqüenciada e apresentou 100\% de identidade com a seqüência gi|42602023|gb|AY454759.1| Uncultured Methanosaeta sp. clone DI_E03 16S ribosomal, depositada no banco de dados do NCBI. Os membros da espécie Methanosaeta, primeiramente descrita por PATEL (1985), correspondem a bacilos embainhados, acetoclásticos estritos, mesofílicos e metanogênicos (GARCIA, 2000; BOONE, 2001).

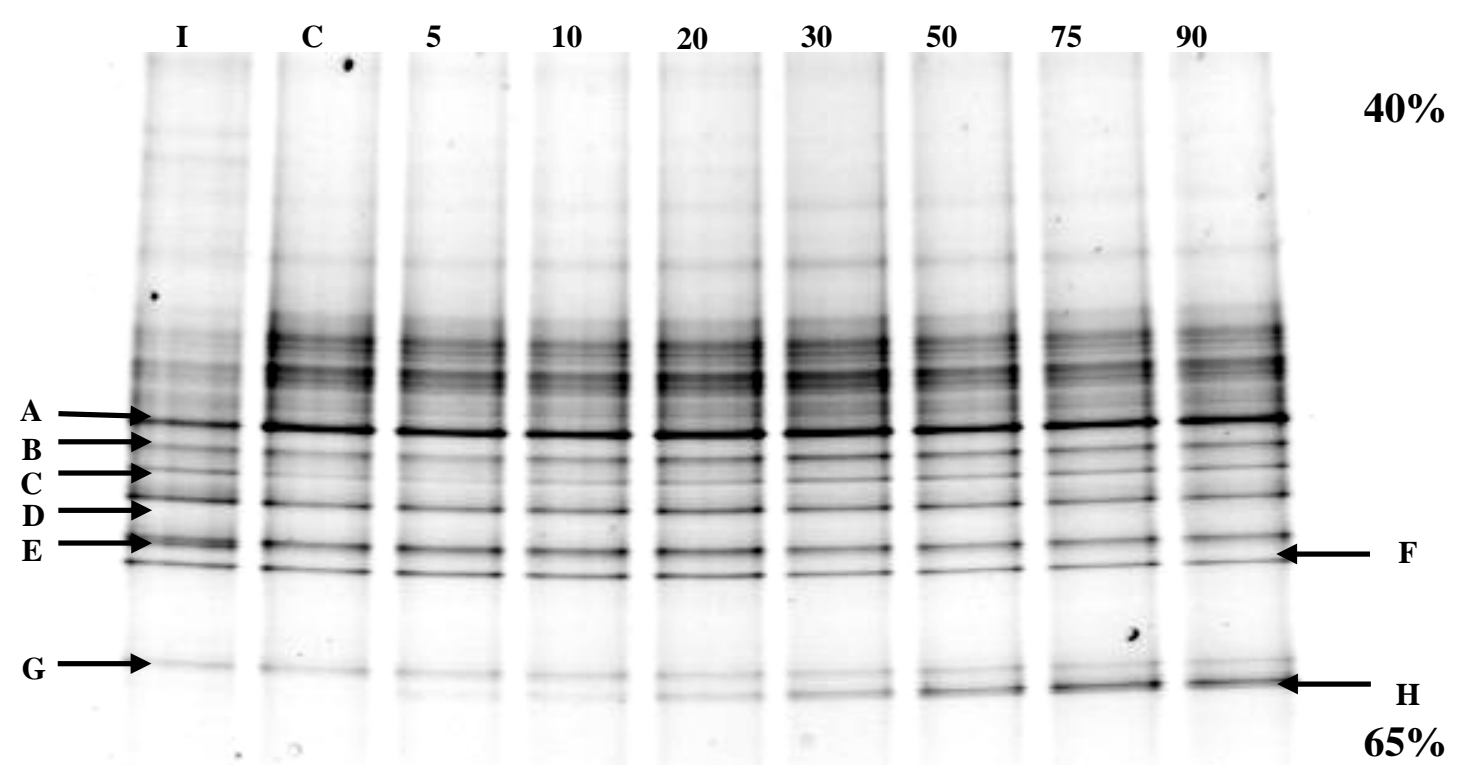

Figura 5.25. Resultados das análises de DGGE dos fragmentos dos produtos de PCR amplificados com primers do Domínio Archaea para as amostras: I-inóculo, C-controle (sem metilamina), 5 (5mM de metilamina), 10 (10mM de metilamina), 20 (20mM de metilamina), 30 (30mM de metilamina), 50 (50mM de metilamina), 75 ( $75 \mathrm{mM}$ de metilamina) e 90 (90mM de metilamina)

A presença de Methanosaeta sp. nos reatores pode ser explicada pela presença de actetato no lodo usado como inóculo. Como a espécie possui baixo Ks para crescimento em acetato, por volta de $0,47 \mathrm{mM}$, que corresponde a $28 \mathrm{mg}$ de acetato (GONZALES-GIL et al., 2001), é possível que a espécie tenha se desenvolvido a partir do acetato residual do lodo. 
Neste trabalho, a concentração inicial de acetato presente nos reatores não foi quantificada, pois as análises de ácidos orgânicos voláteis só começaram a ser realizadas após 15 dias de inoculação, quando a matéria orgânica proveniente do lodo já havia sido previamente esgotada pelos microrganismos. 


\section{CONCLUSÕES}

Os resultados obtidos permitem as seguintes conclusões:

- Em relação à Atividade Metanogênica Específica do lodo (AME) dos reatores pôde-se perceber que o aumento das concentrações de metilamina promoveu aumento na AME. Os melhores resultados foram observados para os reatores com metilamina em concentrações de $50 \mathrm{mM}$ e $75 \mathrm{mM}$, que apresentaram maior produção de metano e maiores velocidades de formação de metano. O modelo cinético de Monod ajustou-se aos dados experimentais, exceto na concentração 90mM de metilamina.

- Os resultados da técnica de Número Mais Provável (NMP) mostraram que quase a totalidade de bactérias anaeróbias totais era composta por arquéias metanogênicas, pois os resultados foram obtidos na mesma ordem de grandeza. Houve ampla diversidade de microrganismos do Domínio Bacteria, representados por bacilos, coco-bacilos, filamento e cocos, e do Domínio Archaea, representados por Methanosarcina sp. e Methanosaeta sp. O seqüenciamento revelou a presença de Methanosaeta sp. mesmo para elevadas concentrações de metilamina. 


\section{PERSPECTIVAS FUTURAS}

Sugere-se:

- Estudo da degradação de metilamina em reator contínuo, para avaliar o comportamento dos microrganismos quando expostos por longos períodos ao composto.

- A realização de ensaios de atividade metanogênica com concentrações de metilamina superiores a $90 \mathrm{mM}$, para tentativa de ajuste de modelo cinético que tenha a inibição de crescimento por excesso de substrato como um de seus parâmetros.

- Processo único de remoção de metilamina, com remoção de $\mathrm{N}$ AMONIACALpor bactérias que promovam a oxidação anaeróbia da amônia a nitrogênio molecular - ANAMMOX. 


\section{REFERÊNCIAS BIBLIOGRÁFICAS}

ADAMS, M. W. W. (1995) Thermophilic Archaea: an overview. In: Archaea - a laboratory manual: Thermophiles. ROBB, F.T. \& PLACE, A.R. (eds.). New York. Cold Spring Harbor Laboratory press 3-7.

ALVAREZ, R. V.; ASPÉ, E. \& URRUTIA, H. (2000) Colonization of supports by methanogenic and sulfate reducing bacteria in anaerobic filter - type reactors. Revista Latinoamericana de Microbiologia 42: 177-180.

APHA, AWWA \& WPCF (2005) Standard Methods for the Examination of Water and Wastewater, 21a. ed, Washington, D.C., Estados Unidos.

ARAÚJO, J. C. (1995) Caracterização e evolução do biofilme em reator anaeróbio de leito fluidificado alimentado com esgoto sanitário sintético. Dissertação de Mestrado, EESC-USP, 158p.

BALCH, W.E.; FOX, G.E.; MAGRUM, L.J.; WOESE, C.R. \& WOLFE, R.S. (1979) Methanogens: reevaluation of a unique biological group. Microbiological Reviews 43 (2): 260-292

BAPTESTE, E.; BROCHIER, C. \& BOUCHER, Y. (2005) Higher-level classification of the Archaea: evolution of methanogenesis and methanogens. Archaea 1: 353-363.

BERG, J. M.; TYMOCZKO, J. L.; STRYER, L. (2004) Bioquímica. Quinta Edição. Editora Guanabara Koogan, Rio de Janeiro-RJ, 1059p.

BERLOW, E. L. (1999) Some effects of weak interactions in ecological communities. Nature 398: 330-334

BOONE, D. R.; MATHRANI, I. M.; LIU, Y.; MENAIA, J. A. G. F.; MAH; R. A. \& BOONE, J. E. (1993) Isolation and characterization of Methanohalophilus portucalensis sp. nov. and DNA reassociation study of the genus Methanohalophilus. International Journal of Systematic Bacteriology 43: 430-437 
BOONE, D., CASTENHOLTZ, R. W. \& GARRITY, G. M. (2001.) Bergey's Manual of Systematic Bacteriology, 2nd ed. Springer-Verlag, New York, NY. 1: 211-213

CHISTOSERDOVA, L.; JENKINS, C.; KALYUZHNAYA, M. G.; MARX, C. J.; LAPIDUS, A.; VORHOLT, J. A.; STALEY, J. T. \& LIDSTROM, M. E. (2004) The enigmatic planctomycetes may hold a key to the origins of methanogenesis and methylotrophy. Molecular Biology and Evolution 21: 1234-1241.

DEL NERY, V.; GIANOTTI, E. P.; DAMIANOVIC, M. H. Z.; DOMINGUES, M. R. \& ZATAT, M. (2002) Granules characteristics in the profile of a plant scale upflow anaerobic sludge blanket reactor treating poultry slaughterhouse wastewater. Anais do VII Simpósio Latinoamericano sobre Digestión Anaeróbia. Mérida, México.

DEPPENMEYER, U.; LIENARD, T. \& GOTTSCHALK, G. (1999) Novel reactions involved in energy conservation by methanogenic Archaea. FEBS Letters 457: 291297.

DOMINGUES, M. R. (2002) Avaliação da metanogênese e sulfetogênese em reatores anaeróbios em batelada e de leito fixo, sob condições termofílicas. Dissertação de Mestrado, 152p.

DUBOURGUIER, H. C. (1987) Curso ecologia da digestão anaeróbia. Companhia de Tecnologia de Saneamento Ambiental do Estado de São Paulo, CETESB, São Paulo.

FERNANDES, A.; HUANG, S.; SESTON, S.; XING, J.; MICKEY, R.; CRIDDLE, C. \& TREDJE, J. (1999) How stable is stable? Function versus community composition. Applied and Environmental Microbiology 65: 3697-3704.

FERRY, J. G. (1999) Enzymology of one-carbon reactions in methanogenic pathways. FEMS Microbiological Reviews 23: 13-38.

GALAGAN, J. E.; NUSBAUM, C. \& ROY, A. (2002) The genome of M. acetivorans reveals extensive metabolic and physiological diversity. Genome Research 12: 532542.

GARCIA, J. L., BHARAT, K. C. P. \& OLLIVIER, B (2000) Taxonomic, phylogenetic and ecological diversity of methanogenic Archaea. Anaerobe 6: 205-226.

GARRITY, G. (2001) Bergey's manual of systematic bacteriology. Editora SpringerVelag, New York, 721p.

GILLAN, D.; SPEKSNIJDER, A.; ZWART, G. \& RIDDER, C. (1998) Genetic diversity of the biofilm covering Montacuta ferruginosa (Mollusca, Bivalvia) as evaluated by denaturing gradient gel electrophoresis analysis and cloning of PCRAmplified gene fragments coding for 16S rRNA. Applied and Environmental Microbiology, 64 (9): 3464-3472. 
GONZALES-GIL, G.; LENS, P. N. L.; VAN AELST, A.; VESPRILLE, A. I. \& LETTINGA, G. (2001) Cluster structure of anaerobic aggregates of an expanded granular sludge bed reactor. Applied and Environmental Microbiology 67 (8): 36833692.

GRAHAM, D. E. \& WHITE, R. H. (2002) Elucidation of methanogenic coenzyme biosyntheses: from spectroscopy to genomics. Natural Products Report 19: 133147.

GRIFFITHS, R. I.; WHITELEY, A. S. \& O’DONNELL, A. G. (2000) Rapid method for coextration of DNA from natural environments for analysis of ribosomal DNA and rRNA-based microbil community composition. Applied and Environmental Microbiology 66(12): 5488-5491.

HUANG, L. N.; ZHOU, H.; CHEN, Y. Q., LUO, S.; LAN, C. Y \& QU, L. H. (2002) Diversity and structure of the archaeal community in the leachate of a full-scale recirculating landfill as examined by direct $16 \mathrm{r}$ RNA gene sequence retrieval. FEMS Microbiology Letters 214: 235-240.

KONIG, H. \& SETTER, A. O. (1989) Archaeobacteria. In: STALEY, J. T.; BRYANT, M. P.; PFENNING, N. \& HOLF, J. G. editors. Bergey's manual of systematic bacteriology. Williams and Wilkins.

KUDO, Y.; NAKAJIMA, T.; MIYAKI, T. \& OYAZU, H. (1997) methanogen flora of paddy soils in Japan. FEMS Microbiology Ecology 22: 39-48.

MADIGAN, M. T.; MARTINKO, J. M . \& PARKER, J. (1997) Brock biology of microorganisms. Prentice Hall, Inc.

MADIGAN, M. T.; MARTINKO, J. M \& PARKER, J. (2004) Microbiologia de Brock. $10^{\mathrm{a}}$ edição. Editora Pearson Education do Brasil, São Paulo, 608 p.

MEUER, J.; KUETTNER, H. C.; ZHANG, J. K.; HEDDERICH, R. \& METCALF, W.W. (2002) Genetic analysys of the archaeon Methanosarcina barkeri Fusaro reveals a central role for Ech hydrogenase and ferredoxin in methanogenesis and carbon fixation. The Proceedings of the Nationa. Academic of Science 99: 56325637.

MORAES, E. M.; ADORNO, M. A. T.; ZAIAT, M. \& FORESTI, E. (2000) determinação de ácidos voláteis por cromatografia gasosa em efluentes de reatores anaeróbios tratando resíduos líquidos e sólidos. Anais da Oficina e Seminário Latino-Americano de Digestão Anaeróbia. Recife-PE. Editora universitária da UFPE 2: 235-238.

MUYZER, G. \& SMALLA, K. (1998) Applications of denaturing gradient gel electrophoresis (DGGE) and temperature gradient gel electrophoresis (TGGE) in microbial ecology / mini review. Antonie van Leeuwenhoek (73) 127-141. 
NIELSEN, A. T.; LIU W. T.; FILIPE, C.; GRADY, L.; MOLIN, S. \& STAHL, D. A. (1999) Identification of a novel group of bacteria in sludge from a deteriorated biological phosphorus removal reactor. Applied and Environmental Microbiology 65 (3)1251-1258.

OLIVEIRA, R. A. (1997) Efeito das concentrações dos sólidos suspensos do afluente no desempenho e características do lodo de reatores anaeróbios de fluxo ascendente com manta de lodo tratando águas residuárias de suinocultura. Tese de Doutorado, EESC-USP, 375p.

OSHA (2006) Ocupational safety \& health administration. U.S. department of labor. http://www.osha.gov/dts/sltc/methods/organic/org040/org040.html. Site visitado em 12/07/2006.

PATEL, G. B. (1984) Characterization and nutritional properties of Methanothrix concilii sp. nov., a mesophilic, aceticlastic methanogen. The Canadian Journal of Microbiology 30: 1383-1396

PATEL, G. B. (1985) Validation of the publication of new names and new combinations previously effectively published outside the IJSB. List No. 17 International Journal of Systematic Bacteriology 35: 223-225

REEVE, J. N.; NOLLING, R. M. M. \& SMITH, D. R. (1997) Methanogenesis: genes, genomes, and who's on first. Journal of Bacteriology (179) 5975-5986.

ROBICHAUZ, M.; HOWELL, M. \& BOOPATHY, R. (2003) Methanogenic activity in human periodontal pocket. Current Microbiology 46: 53-58

SAKAMOTO, I. K. (2001) Comparação da estrutura de comunidades microbianas presentes em sistemas de lodos ativados modificados por remoção biológica do fósforo em excesso, utilizando técnicas de eletroforese em gel de gradiente desnaturante (DGGE). Tese de Doutorado, EESC-USP.

SCHWÖRER, B. \& THAUER, R. K. (1991) Activities of formylmethanofuran dehydrogenase, methylenetetrahydromethanopterin dehydrogenase, methylenetetrahydromethanopterin reductase, and heterodisulfide reductase in methanogenic bacteria. Archives of Microbiology 155: 459-465.

SOWERS, K. R.; THAI, T. T. \& GUNSALUS, R. P. (1993) Transcriptional regulation of the carbon monoxide dehydrogenase gene (cdhA) in Methanosarcina thermophila. Journal of Biological Chemistry 268: 23172-23178

STEIL, L. (2001) Avaliação do uso de inóculos na biodigestão anaeróbia de resíduos de aves de postura, frangos de corte e suínos. Dissertação de Mestrado, UNESPAraraquara. 
TAKAI, K.; MOSER, D. P.; DEFLAUN, M.; ONSTOTT, T. C. \& FREDRICKSON, J. K. (2001) Archaeal diversity in waters from waters from deep South African gold mines. Applied and Environmental Microbiology 67: 5750-5760.

TOUZEL, J. P. \& ALBAGNAC, G. (1983) Isolation and characterization of Methanococcus mazei strain MC3. FEMS Microbiology Letters 16: 241-245.

VAN DE WIJNGAARD, W. M.; CREEMERS, J.; VOGELS, G. D. \& VAN DER DRIFT, C. (2002) Methanogenic pathways in Methanospaera stadtmanae. FEMS Microbiology Letters 64: 207-211.

VAZOLLER, R. F. (1995) Avaliação do ecossistema microbiano de um biodigestor anaeróbio de fluxo ascendente e manta de lodo, operado com vinhaça sob condições termofílicas. Tese de Doutorado, EESC-USP.

WALKER, B. (1995) Conserving billogical diversity through ecosystem resilience. Conservation Biology 9: 747-752.

WARD, D. M.; WELLER, R. \& BATESON, M. M. (1990) Effect of oxygen status on pesticide transformation and sorption in undisturbed soil and lake sediment. Environmental Toxicology and Chemistry 16 (4) 608-616.

WHITMAN, W. B.; BOONE, D. R.; KOGA, Y. \& KESWANI, J. (2001). Taxonomy of methanogenic Archaea. In: BOONE, D., CASTENHOLTZ, R. W. \& GARRITY, G. M. (Eds.) Bergey's Manual of Systematic Bacteriology, 2nd ed. Springer-Verlag, New York, NY. 1: 211-213

ZINDER, S. H.; CARDWELL, S. C.; ANGUISH, T.; LEE, M. \& KOCH, M. (1984) Methanogenesis in a thermophilic $\left(58^{\circ} \mathrm{C}\right)$ anaerobic digestor. Methanothrix sp. as an important acetoclastic methanogen. Applied and Environmental Microbiology 47: 796-807.

ZINDER, S. H. (1993) Physiological Ecology of Methanogens. In: FERRY, J. G. Methanogenesis. Ecology, Physiology, Biochemistry and Genetics. Chapman \& Hall, London, UK. 128-206.

ZHU, X. Y.; LUBECK, J. \& KILBANELL, J. J. (2003) Characterization of microbial communities in gas industry pipelines. Applied and Environmental Microbiology 69: $5354-5363$ 
APÊNDICE 1 - Tempo de experimento, área cromatográfica e valores de metano acumulado no headspace dos reatores anaeróbios em batelada alimentados com metilamina.

\begin{tabular}{|c|c|c|c|c|c|}
\hline \multicolumn{6}{|c|}{ Controle } \\
\hline \multicolumn{3}{|c|}{ REATOR (1) } & \multicolumn{3}{|c|}{ REATOR (2) } \\
\hline Tempo (h) & $\begin{array}{c}\text { Área } \\
\text { Cromatográfica } \\
\text { do Metano }\end{array}$ & $\begin{array}{c}\text { Concentração } \\
\text { de Metano no } \\
\text { headspace } \\
\text { (mmol/L) }\end{array}$ & Tempo (h) & $\begin{array}{c}\text { Área } \\
\text { Cromatográfica } \\
\text { do Metano }\end{array}$ & $\begin{array}{c}\text { Concentração } \\
\text { de Metano no } \\
\text { headspace } \\
\text { (mmol/L) }\end{array}$ \\
\hline 0,00 & 1455 & 1,400 & 0,00 & 694 & 1,357 \\
\hline 5,55 & 2374 & 1,452 & 5,45 & 2925 & 1,483 \\
\hline 19,28 & 5297 & 1,616 & 19,20 & 6196 & 1,667 \\
\hline 22,73 & 4764 & 1,586 & 22,63 & 6234 & 1,669 \\
\hline 48,05 & 7194 & 1,723 & 48,12 & 12166 & 2,002 \\
\hline 50,12 & 8077 & 1,772 & 50,02 & 13729 & 2,090 \\
\hline 54,45 & 10301 & 1,897 & 54,33 & 17252 & 2,288 \\
\hline 66,23 & 12035 & 1,995 & 66,15 & 18654 & 2,366 \\
\hline 72,00 & 14897 & 2,155 & 71,88 & 20147 & 2,450 \\
\hline 76,18 & 14912 & 2,156 & 76,08 & 23014 & 2,611 \\
\hline 93,95 & 16200 & 2,229 & 93,87 & 29060 & 2,951 \\
\hline 102,88 & 11730 & 1,977 & 98,45 & 21442 & 2,523 \\
\hline 116,87 & 18822 & 2,376 & 102,77 & 19253 & 2,400 \\
\hline 120,78 & 17130 & 2,281 & 116,82 & 30347 & 3,023 \\
\hline 123,85 & 14791 & 2,149 & 120,77 & 28998 & 2,947 \\
\hline 128,22 & 18166 & 2,339 & 123,73 & 24240 & 2,680 \\
\hline 139,82 & 18092 & 2,335 & 128,10 & 29978 & 3,003 \\
\hline 162,90 & 22227 & 2,567 & 139,88 & 29541 & 2,978 \\
\hline
\end{tabular}

\begin{tabular}{c|c|c|c|c|c}
\hline \multicolumn{5}{c}{$\mathbf{5 m M}$ de metilamina } \\
\hline \multicolumn{7}{c}{ REATOR (1) } & \multicolumn{3}{c}{ REATOR (2) } \\
\hline Tempo (h) & $\begin{array}{c}\text { Área } \\
\text { Cromatográfica } \\
\text { do Metano }\end{array}$ & $\begin{array}{c}\text { Concentração } \\
\text { de Metano no } \\
\text { headspace } \\
\text { (mmo//L) }\end{array}$ & Tempo (h) & $\begin{array}{c}\text { Área } \\
\text { Cromatográfica } \\
\text { do Metano }\end{array}$ & $\begin{array}{c}\text { Concentração } \\
\text { de Metano no } \\
\text { headspace } \\
\text { (mmol/L) }\end{array}$ \\
\hline 0,00 & 5632 & 1,635 & 0,00 & 1585 & 1,408 \\
5,35 & 6438 & 1,680 & 5,20 & 2960 & 1,485 \\
19,13 & 14024 & 2,106 & 19,00 & 10842 & 1,928 \\
22,55 & 15733 & 2,202 & 22,42 & 5629 & 1,635 \\
48,03 & 37647 & 3,433 & 47,93 & 36375 & 3,362 \\
49,93 & 44417 & 3,814 & 49,82 & 47414 & 3,982 \\
54,25 & 54021 & 4,353 & 54,13 & 57511 & 4,549 \\
66,07 & 58641 & 4,613 & 65,93 & 61478 & 4,772 \\
71,82 & 65478 & 4,997 & 71,70 & 70584 & 5,284 \\
76,00 & 80478 & 5,839 & 75,87 & 82417 & 5,948 \\
93,78 & 93345 & 6,562 & 93,65 & 87826 & 6,252 \\
116,73 & 99488 & 6,907 & 98,27 & 71209 & 5,319 \\
120,70 & 98747 & 6,866 & 102,53 & 67023 & 5,084 \\
123,63 & 93255 & 6,557 & 116,58 & 93687 & 6,581 \\
128,00 & 75613 & 5,566 & 120,57 & 87510 & 6,234 \\
139,78 & 87755 & 6,248 & 123,48 & 90525 & 6,404 \\
162,70 & 95450 & 6,680 & 127,85 & 71017 & 5,308 \\
& & & 139,63 & 83616 & 6,016 \\
& & & 162,55 & 91411 & 6,454 \\
\hline
\end{tabular}




\begin{tabular}{c|c|c|c|c|c}
\hline \multicolumn{5}{c}{ 10mM de metilamina } \\
\hline & \multicolumn{2}{c}{ REATOR (1) } & \multicolumn{2}{c}{ REATOR (2) } \\
\hline Tempo (h) & $\begin{array}{c}\text { Área } \\
\text { Cromatográfica } \\
\text { do Metano }\end{array}$ & $\begin{array}{c}\text { Concentração } \\
\text { de Metano no } \\
\text { headspace } \\
\text { (mmol/L) }\end{array}$ & Tempo (h) & $\begin{array}{c}\text { Área } \\
\text { Cromatográfica } \\
\text { do Metano }\end{array}$ & $\begin{array}{c}\text { Concentração } \\
\text { de Metano no } \\
\text { headspace } \\
\text { (mmol/L) }\end{array}$ \\
\hline 0,00 & 1225 & 1,387 & 0,00 & 1240 & 1,388 \\
5,15 & 3048 & 1,490 & 5,07 & 3425 & 1,511 \\
18,97 & 11480 & 1,963 & 18,88 & 10616 & 1,915 \\
22,37 & 13637 & 2,085 & 22,32 & 11665 & 1,974 \\
47,88 & 37991 & 3,453 & 47,80 & 38014 & 3,454 \\
49,78 & 43429 & 3,758 & 49,73 & 38598 & 3,487 \\
54,08 & 60317 & 4,707 & 54,00 & 52823 & 4,286 \\
65,90 & 68741 & 5,180 & 65,85 & 62478 & 4,828 \\
71,65 & 75847 & 5,579 & 71,58 & 75471 & 5,558 \\
75,82 & 87417 & 6,229 & 75,73 & 89478 & 6,345 \\
93,65 & 91730 & 6,471 & 93,60 & 109526 & 7,471 \\
98,23 & 108185 & 7,396 & 98,17 & 108506 & 7,414 \\
102,47 & 103514 & 7,133 & 102,40 & 108905 & 7,436 \\
116,52 & 145638 & 9,500 & 116,45 & 144579 & 9,440 \\
120,53 & 186685 & 11,806 & 120,45 & 135162 & 8,911 \\
123,43 & 138750 & 9,113 & 123,35 & 139513 & 9,156 \\
127,80 & 107794 & 7,374 & 127,72 & 110341 & 7,517 \\
139,58 & 126662 & 8,434 & 139,50 & 126694 & 8,436 \\
162,48 & 138756 & 9,113 & 162,42 & 135841 & 8,949 \\
\hline
\end{tabular}

\begin{tabular}{c|c|c|c|c|c}
\hline \multicolumn{5}{c}{ 20mM de metilamina } \\
\hline \multicolumn{7}{c}{ REATOR (1) } & $\begin{array}{c}\text { REATOR (2) } \\
\text { Tempo (h) }\end{array}$ & $\begin{array}{c}\text { Área } \\
\text { Cromatográfica } \\
\text { do Metano }\end{array}$ & $\begin{array}{c}\text { Concentração } \\
\text { de Metano no } \\
\text { headspace } \\
\text { (mmo//L) }\end{array}$ & Tempo (h) & $\begin{array}{c}\text { Área } \\
\text { Cromatográfica } \\
\text { do Metano }\end{array}$ & $\begin{array}{c}\text { Concentração } \\
\text { de Metano no } \\
\text { headspace } \\
\text { (mmol/L) }\end{array}$ \\
\hline 0,00 & 2815 & 0,290 & 0,00 & 4933 & 1,596 \\
5,08 & 6133 & 0,476 & 4,85 & 6021 & 1,657 \\
18,90 & 15638 & 1,010 & 18,68 & 14537 & 2,135 \\
22,33 & 17022 & 1,088 & 22,23 & 14044 & 2,107 \\
43,30 & 38339 & 2,286 & 42,98 & 36267 & 3,356 \\
47,85 & 39673 & 2,361 & 47,55 & 37678 & 3,435 \\
51,22 & 47258 & 2,787 & 50,88 & 43107 & 3,740 \\
54,05 & 58761 & 3,433 & 53,73 & 57725 & 4,561 \\
65,87 & 70154 & 4,073 & 65,63 & 70147 & 5,259 \\
71,62 & 86214 & 4,975 & 71,42 & 98745 & 6,866 \\
75,75 & 107485 & 6,170 & 75,53 & 116845 & 7,882 \\
93,68 & 137700 & 7,867 & 93,42 & 124426 & 8,308 \\
98,20 & 153230 & 8,740 & 97,98 & 140486 & 9,210 \\
102,40 & 142625 & 8,144 & 102,17 & 154709 & 10,009 \\
116,67 & 260015 & 14,738 & 116,43 & 248804 & 15,295 \\
120,42 & 240165 & 13,623 & 120,22 & 231647 & 14,331 \\
123,35 & 251212 & 14,244 & 123,13 & 239550 & 14,775 \\
127,72 & 199220 & 11,323 & 127,48 & 180383 & 11,452 \\
139,53 & 226686 & 12,866 & 139,27 & 217752 & 13,551 \\
162,42 & 240029 & 13,616 & 162,18 & 233317 & 14,425 \\
\hline
\end{tabular}




\begin{tabular}{c|c|c|c|c|c}
\hline \multicolumn{5}{c}{ 30mM de metilamina } \\
\hline \multicolumn{7}{c}{ REATOR (1) } & $\begin{array}{c}\text { REATOR (2) } \\
\text { Tempo (h) }\end{array}$ & $\begin{array}{c}\text { Área } \\
\text { Cromatográfica } \\
\text { do Metano }\end{array}$ & $\begin{array}{c}\text { Concentração } \\
\text { de Metano no } \\
\text { headspace } \\
\text { (mmol/L) }\end{array}$ & Tempo (h) & $\begin{array}{c}\text { Área } \\
\text { Cromatográfica } \\
\text { do Metano }\end{array}$ & $\begin{array}{c}\text { Concentração } \\
\text { de Metano no } \\
\text { headspace } \\
\text { (mmol/L) }\end{array}$ \\
\hline 0,00 & 1658 & 1,412 & 0,00 & 811 & 1,364 \\
4,63 & 2789 & 1,475 & 4,77 & 3495 & 1,515 \\
18,48 & 11379 & 1,958 & 18,63 & 12644 & 2,029 \\
21,87 & 13025 & 2,050 & 22,08 & 14044 & 2,107 \\
42,82 & 32529 & 3,146 & 42,97 & 34906 & 3,279 \\
47,38 & 34292 & 3,245 & 47,55 & 37335 & 3,416 \\
50,85 & 39481 & 3,536 & 51,00 & 43708 & 3,774 \\
53,60 & 52966 & 4,294 & 53,75 & 52030 & 4,241 \\
65,45 & 65478 & 4,997 & 65,62 & 70145 & 5,259 \\
71,22 & 76547 & 5,619 & 71,38 & 89478 & 6,345 \\
75,35 & 89847 & 6,366 & 75,52 & 120147 & 8,068 \\
93,28 & 109287 & 7,458 & 93,43 & 125281 & 8,356 \\
97,80 & 125812 & 8,386 & 97,93 & 143600 & 9,385 \\
101,95 & 134267 & 8,861 & 102,08 & 154170 & 9,979 \\
116,23 & 273276 & 16,670 & 116,43 & 300261 & 18,186 \\
120,00 & 293314 & 17,796 & 120,62 & 321295 & 19,368 \\
122,93 & 332615 & 20,003 & 123,07 & 338832 & 20,353 \\
127,35 & 271384 & 16,564 & 127,42 & 261651 & 16,017 \\
139,05 & 314972 & 19,012 & 139,20 & 306135 & 18,516 \\
161,97 & 338659 & 20,343 & 162,10 & 324982 & 19,575 \\
\hline
\end{tabular}

\begin{tabular}{c|c|c|c|c|c}
\hline \multicolumn{5}{c}{ 50mM de metilamina } \\
\hline \multicolumn{7}{c}{ REATOR (1) } & \multicolumn{3}{c}{ REATOR (2) } \\
\hline Tempo (h) & $\begin{array}{c}\text { Área } \\
\text { Cromatográfica } \\
\text { do Metano }\end{array}$ & $\begin{array}{c}\text { Concentração } \\
\text { de Metano no } \\
\text { headspace } \\
\text { (mmol/L) }\end{array}$ & Tempo (h) & $\begin{array}{c}\text { Área } \\
\text { Cromatográfica } \\
\text { do Metano }\end{array}$ & $\begin{array}{c}\text { Concentração } \\
\text { de Metano no } \\
\text { headspace } \\
\text { (mmol/L) }\end{array}$ \\
\hline 0,00 & 1315 & 1,392 & 0,00 & 2103 & 1,437 \\
18,48 & 11451 & 1,962 & 4,55 & 5549 & 1,630 \\
21,95 & 13033 & 2,051 & 18,67 & 698 & 1,358 \\
42,80 & 31675 & 3,098 & 42,75 & 14758 & 2,148 \\
47,37 & 32936 & 3,169 & 47,32 & 17114 & 2,280 \\
50,87 & 37844 & 3,444 & 50,87 & 20357 & 2,462 \\
53,57 & 50842 & 4,175 & 53,52 & 19970 & 2,440 \\
65,47 & 70458 & 5,277 & 65,42 & 25478 & 2,750 \\
71,23 & 78254 & 5,714 & 71,22 & 34911 & 3,280 \\
75,37 & 85478 & 6,120 & 75,35 & 56789 & 4,509 \\
93,25 & 99714 & 6,920 & 93,22 & 71031 & 5,309 \\
97,78 & 106499 & 7,301 & 97,75 & 80691 & 5,851 \\
101,90 & 120341 & 8,079 & 101,88 & 87444 & 6,231 \\
116,25 & 244277 & 15,041 & 116,40 & 181663 & 11,524 \\
120,47 & 256820 & 15,746 & 120,42 & 190244 & 12,006 \\
122,88 & 287491 & 17,469 & 122,83 & 218542 & 13,595 \\
127,28 & 238067 & 14,692 & 127,23 & 190441 & 12,017 \\
139,02 & 394035 & 23,454 & 138,97 & 309712 & 18,717 \\
146,97 & 456471 & 26,961 & 146,93 & 402566 & 23,933 \\
161,93 & 519322 & 30,492 & 161,88 & 496494 & 29,210 \\
170,17 & 640004 & 37,271 & 170,12 & 617325 & 35,997 \\
175,25 & 493310 & 29,031 & 175,18 & 641951 & 37,381 \\
186,63 & 504691 & 29,670 & 186,55 & 479432 & 28,251 \\
\hline & & & & & \\
\hline
\end{tabular}




\begin{tabular}{|c|c|c|c|c|c|}
\hline \multicolumn{6}{|c|}{ 75mM de metilamina } \\
\hline \multicolumn{3}{|c|}{ REATOR (1) } & \multicolumn{3}{|c|}{ REATOR (2) } \\
\hline Tempo (h) & $\begin{array}{c}\text { Área } \\
\text { Cromatográfica } \\
\text { do Metano }\end{array}$ & $\begin{array}{c}\text { Concentração } \\
\text { de Metano no } \\
\text { headspace } \\
(\mathrm{mmol} / \mathrm{L})\end{array}$ & Tempo (h) & $\begin{array}{c}\text { Área } \\
\text { Cromatográfica } \\
\text { do Metano }\end{array}$ & $\begin{array}{c}\text { Concentração } \\
\text { de Metano no } \\
\text { headspace } \\
\text { (mmol/L) }\end{array}$ \\
\hline 0,00 & 3430 & 1,511 & 0,00 & 1410 & 1,398 \\
\hline 3,33 & 7641 & 1,748 & 3,28 & 2939 & 1,484 \\
\hline 17,05 & 16871 & 2,266 & 17,02 & 12459 & 2,018 \\
\hline 20,52 & 18157 & 2,338 & 20,48 & 13808 & 2,094 \\
\hline 41,42 & 36114 & 3,347 & 41,38 & 30368 & 3,024 \\
\hline 46,00 & 36225 & 3,353 & 45,98 & 26728 & 2,820 \\
\hline 49,52 & 38009 & 3,454 & 49,47 & 31801 & 3,105 \\
\hline 51,45 & 41167 & 3,631 & 51,78 & 34606 & 3,262 \\
\hline 64,07 & 63147 & 4,866 & 64,05 & 54784 & 4,396 \\
\hline 69,88 & 81478 & 5,896 & 69,85 & 65884 & 5,020 \\
\hline 74,02 & 97665 & 6,805 & 73,98 & 98441 & 6,848 \\
\hline 90,82 & 123290 & 8,244 & 90,85 & 104770 & 7,204 \\
\hline 99,77 & 86762 & 6,192 & 99,78 & 66581 & 5,059 \\
\hline 114,35 & 180833 & 11,477 & 114,28 & 157499 & 10,166 \\
\hline 119,10 & 184886 & 11,705 & 119,03 & 164077 & 10,536 \\
\hline 121,47 & 203556 & 12,753 & 121,43 & 181831 & 11,533 \\
\hline 125,88 & 181507 & 11,515 & 125,82 & 153572 & 9,946 \\
\hline 137,62 & 264592 & 16,182 & 137,57 & 236130 & 14,583 \\
\hline 145,60 & 341788 & 20,519 & 145,55 & 318744 & 19,224 \\
\hline 160,53 & 482491 & 28,423 & 160,47 & 434720 & 25,739 \\
\hline 168,77 & 704036 & 40,868 & 168,72 & 642534 & 37,414 \\
\hline 173,82 & 803761 & 46,471 & 173,80 & 526723 & 30,908 \\
\hline 185,23 & 741479 & 42,972 & 185,20 & 423183 & 25,091 \\
\hline 188,68 & 738571 & 42,809 & & & \\
\hline 191,38 & 729841 & 42,318 & & & \\
\hline 196,55 & 721547 & 41,852 & & & \\
\hline
\end{tabular}




\begin{tabular}{c|c|c|c|c|c}
\hline \multicolumn{5}{c}{ 90mM de metilamina } \\
\hline \multicolumn{7}{c}{ REATOR (1) } & \multicolumn{3}{c}{ REATOR (2) } \\
\hline Tempo (h) & $\begin{array}{c}\text { Área } \\
\text { Cromatográfica } \\
\text { do Metano }\end{array}$ & $\begin{array}{c}\text { Concentração } \\
\text { de Metano no } \\
\text { headspace } \\
\text { (mmol/L) }\end{array}$ & Tempo (h) & $\begin{array}{c}\text { Área } \\
\text { Cromatográfica } \\
\text { do Metano }\end{array}$ & $\begin{array}{c}\text { Concentração } \\
\text { de Metano no } \\
\text { headspace } \\
\text { (mmol/L) }\end{array}$ \\
\hline 0,00 & 896 & 1,369 & 0,00 & 19871 & 2,435 \\
3,20 & 3612 & 1,521 & 3,08 & 18759 & 2,372 \\
16,93 & 11852 & 1,984 & 16,82 & 30067 & 3,008 \\
20,43 & 13762 & 2,092 & 20,30 & 30806 & 3,049 \\
41,28 & 30619 & 3,039 & 41,15 & 50834 & 4,174 \\
45,90 & 30317 & 3,022 & 49,25 & 59986 & 4,688 \\
49,38 & 35891 & 3,335 & 51,17 & 73434 & 5,444 \\
51,30 & 33777 & 3,216 & 63,85 & 88774 & 6,305 \\
63,97 & 56478 & 4,491 & 69,63 & 105477 & 7,244 \\
69,77 & 73147 & 5,428 & 73,80 & 139784 & 9,171 \\
73,92 & 92488 & 6,514 & 90,65 & 162906 & 10,470 \\
90,78 & 108293 & 7,402 & 99,60 & 126042 & 8,399 \\
99,73 & 126018 & 8,398 & 114,08 & 242804 & 14,958 \\
114,23 & 185958 & 11,765 & 118,82 & 250525 & 15,392 \\
118,93 & 172138 & 10,989 & 121,20 & 277650 & 16,916 \\
121,33 & 188250 & 11,894 & 125,60 & 228586 & 14,160 \\
125,73 & 162247 & 10,433 & 137,37 & 364516 & 21,796 \\
137,48 & 253207 & 15,543 & 145,38 & 478113 & 28,177 \\
145,50 & 361224 & 21,611 & 160,25 & 649785 & 37,821 \\
160,38 & 457541 & 27,021 & 168,48 & 881863 & 50,858 \\
168,62 & 664091 & 38,625 & 173,57 & 924013 & 53,226 \\
173,72 & 545039 & 31,937 & 185,00 & 681143 & 39,582 \\
185,12 & 526367 & 30,888 & 187,52 & 574147 & 33,572 \\
187,92 & 450147 & 26,606 & & & \\
\hline
\end{tabular}


APÊNDICE 2 - Determinação da velocidade máxima de produção de metano nos reatores anaeróbios em batelada alimentados com metilamina

\begin{tabular}{|c|c|c|c|}
\hline \multicolumn{4}{|c|}{$5 \mathrm{mM}$} \\
\hline \multicolumn{2}{|c|}{ Reator (1) } & \multicolumn{2}{|c|}{ Reator (2) } \\
\hline Tempo (h) & $\begin{array}{c}\text { Velocidade de } \\
\text { Formação do } \\
\text { Metano } \\
\text { (mmol/L.h) }\end{array}$ & Tempo (h) & $\begin{array}{c}\text { Velocidade de } \\
\text { Formação do } \\
\text { Metano } \\
\text { (mmol/L.h) }\end{array}$ \\
\hline 0,0 & 0,01038 & 0,0 & 0,00941 \\
\hline 2,8 & 0,0113 & 2,8 & 0,01046 \\
\hline 5,5 & 0,01329 & 5,5 & 0,01278 \\
\hline 8,3 & 0,01559 & 8,3 & 0,01555 \\
\hline 11,0 & 0,01823 & 11,0 & 0,01886 \\
\hline 13,8 & 0,02125 & 13,8 & 0,02276 \\
\hline 16,5 & 0,02466 & 16,5 & 0,0273 \\
\hline 19,3 & 0,02848 & 19,3 & 0,03253 \\
\hline 22,1 & 0,03271 & 22,0 & 0,03845 \\
\hline 24,8 & 0,03733 & 24,8 & 0,045 \\
\hline 27,6 & 0,04229 & 27,6 & 0,05208 \\
\hline 30,3 & 0,04752 & 30,3 & 0,0595 \\
\hline 33,1 & 0,05291 & 33,1 & 0,06697 \\
\hline 35,8 & 0,0583 & 35,8 & 0,07414 \\
\hline 38,6 & 0,06352 & 38,6 & 0,08057 \\
\hline 41,4 & 0,06836 & 41,3 & 0,08583 \\
\hline 44,1 & 0,0726 & 44,1 & 0,08952 \\
\hline 46,9 & 0,07603 & 46,8 & 0,09132 \\
\hline 49,6 & 0,07846 & 49,6 & 0,09108 \\
\hline 52,4 & 0,07976 & 52,3 & 0,08882 \\
\hline 55,2 & 0,07983 & 55,1 & 0,08474 \\
\hline 57,9 & 0,07868 & 57,9 & 0,07917 \\
\hline 60,7 & 0,07638 & 60,6 & 0,07252 \\
\hline 63,4 & 0,07306 & 63,4 & 0,06525 \\
\hline 66,2 & 0,06891 & 66,1 & 0,05776 \\
\hline 68,9 & 0,06413 & 68,9 & 0,0504 \\
\hline 71,7 & 0,05894 & 71,6 & 0,04343 \\
\hline 74,5 & 0,05356 & 74,4 & 0,03701 \\
\hline 77,2 & 0,04816 & 77,1 & 0,03126 \\
\hline 80,0 & 0,04291 & 79,9 & 0,02619 \\
\hline 82,7 & 0,03791 & 82,7 & 0,0218 \\
\hline 85,5 & 0,03325 & 85,4 & 0,01804 \\
\hline 88,2 & 0,02897 & 88,2 & 0,01487 \\
\hline 91,0 & 0,0251 & 90,9 & 0,0122 \\
\hline 93,8 & 0,02164 & & \\
\hline 96,5 & 0,01857 & & \\
\hline 99,3 & 0,01589 & & \\
\hline 102,0 & 0,01355 & & \\
\hline 104,8 & 0,01152 & & \\
\hline 107,5 & 0,00978 & & \\
\hline 110,3 & 0,00828 & & \\
\hline 113,1 & 0,007 & & \\
\hline 115,8 & 0,00591 & & \\
\hline 118,6 & 0,00499 & & \\
\hline
\end{tabular}

Velocidade máxima de formação de metano. 


\begin{tabular}{|c|c|c|c|}
\hline \multicolumn{4}{|c|}{$10 \mathrm{mM}$} \\
\hline \multicolumn{2}{|c|}{ Reator (1) } & \multicolumn{2}{|c|}{ Reator (2) } \\
\hline Tempo (h) & $\begin{array}{c}\text { Velocidade de } \\
\text { Formação do } \\
\text { Metano } \\
\text { (mmol/L.h) }\end{array}$ & empo (h) & $\begin{array}{l}\text { Velocidade de } \\
\text { Formação do } \\
\text { (mmol/L.h) }\end{array}$ \\
\hline 0,0 & & 0,0 & \\
\hline 2,8 & 0,0223 & 2,8 & 0,01556 \\
\hline 5,5 & & 5,5 & \\
\hline 8,3 & 0,02705 & 8,3 & 0,01998 \\
\hline & 0,0297 & 11,0 & 0,02258 \\
\hline 13,8 & 0,03254 & 13,8 & 0,02546 \\
\hline 16,5 & 0,03557 & 16,5 & 0,02863 \\
\hline 19,3 & 0,03879 & 19,3 & 0,0321 \\
\hline 22,0 & & 22,0 & 0,03589 \\
\hline 24,8 & 0,04572 & 24,8 & 0,03998 \\
\hline 27,5 & 0,0494 & & 0,04436 \\
\hline 30,3 & 0,05318 & 30,3 & 0,04901 \\
\hline 33,0 & 0,05704 & 33,0 & \\
\hline 35,8 & 0,06093 & & \\
\hline 38,6 & 0,0648 & 38,5 & 0,06411 \\
\hline & 0,06859 & 41,3 & \\
\hline & 0,07224 & 44,0 & 0,07437 \\
\hline 46,8 & 0,0757 & 46,8 & 07925 \\
\hline 49,6 & 0,0789 & 49,6 & 0838 \\
\hline & 0,08176 & 52,3 & 0 \\
\hline 55,1 & 0,08424 & 55,1 & \\
\hline & & 57,8 & 0,09423 \\
\hline 60,6 & 0,08779 & 60,6 & 0,09625 \\
\hline 63,3 & 0,08879 & 63,3 & \\
\hline 66,1 & 0,08922 & 66,1 & 0,09761 \\
\hline & & & 0,09691 \\
\hline 71,6 & 0,08839 & 71,6 & 0,09532 \\
\hline & & 74,3 & 0,09289 \\
\hline 77,1 & 0,08538 & 77,1 & 0,0897 \\
\hline 79,9 & & 79,8 & 0,08587 \\
\hline 82,6 & 0,08047 & 82,6 & 0,08152 \\
\hline 88,1 & 0,07412 & 88,1 & 0,07178 \\
\hline 93,6 & 0,06683 & 93,6 & 0,06145 \\
\hline 99,1 & 0 , & 99,1 & 0,05136 \\
\hline 101,9 & 0,05524 & 101,9 & 0,0466 \\
\hline 104,6 & 0,05141 & 104,6 & 0,04208 \\
\hline
\end{tabular}

Velocidade máxima de formação de metano. 


\begin{tabular}{|c|c|c|c|}
\hline \multicolumn{4}{|c|}{$20 \mathrm{mM}$} \\
\hline \multicolumn{2}{|c|}{ Reator (1) } & \multicolumn{2}{|c|}{ Reator (2) } \\
\hline Tempo (h) & $\begin{array}{l}\text { Fo } \\
\text { Metano } \\
\text { (mmol/L.h) }\end{array}$ & Tempo (h) & $\begin{array}{l}\text { Fo } \\
\text { Metano } \\
\text { (mmol/L.h) } \\
\end{array}$ \\
\hline 0,0 & 0,00954 & 0,0 & 0,01311 \\
\hline & 0,01021 & 2,7 & 0,01396 \\
\hline 5,5 & & 5,5 & 0,01575 \\
\hline 8,3 & 0,01331 & 8,2 & \\
\hline 11,0 & 0,01517 & 11,0 & 0,02002 \\
\hline 13,8 & 0,01728 & 13,7 & 0,02253 \\
\hline 16,5 & 0,01967 & & 0,02533 \\
\hline 19,3 & 0,02237 & 19,2 & 0,02845 \\
\hline & 0,0254 & 22,0 & 0,03189 \\
\hline 24,8 & & 24,7 & 0,0357 \\
\hline 27,5 & 0,03262 & 27,5 & \\
\hline 30,3 & 0,03687 & 30,2 & 0,04448 \\
\hline 33,0 & 0,04159 & 33,0 & 0,04949 \\
\hline 35,8 & 0,04681 & & 0,05492 \\
\hline 38,5 & 0,05255 & 38,5 & 0,06077 \\
\hline & 0,05883 & 41,2 & 0,06704 \\
\hline 44,0 & & 44,0 & 0,07371 \\
\hline 46,8 & 0,07301 & 46,7 & \\
\hline 49,6 & 0,08087 & 49,5 & 0,08806 \\
\hline 52,3 & 0,08919 & 52,2 & 0,09562 \\
\hline 55,1 & 0,09789 & & 0,10333 \\
\hline 57,8 & 0,10688 & 57,7 & 0,11108 \\
\hline & 0,11602 & 60,5 & 0,11873 \\
\hline 63,3 & & 63,2 & 0,12614 \\
\hline 66,1 & 0,13413 & 66,0 & \\
\hline 68,8 & 0,1427 & 68,7 & 0,13962 \\
\hline 71,6 & 0,15066 & 71,5 & 0,14536 \\
\hline & 0,15779 & & 0,15022 \\
\hline 77,1 & 0,16386 & 77,0 & 0,15406 \\
\hline & 0,16869 & 79,7 & 0,15678 \\
\hline 82,6 & & 82,5 & 0,15827 \\
\hline 85,3 & 0,17395 & 85,2 & \\
\hline 88,1 & 0,17421 & 88,0 & 0,15746 \\
\hline 90,8 & 0,17284 & 90,7 & 0,15518 \\
\hline 93,6 & 0,16991 & & 0,15173 \\
\hline 96,4 & 0,16552 & 96,2 & 0,14722 \\
\hline & 0,15982 & 99,0 & 0,14178 \\
\hline 101,9 & & 101,7 & 0,13556 \\
\hline 104,6 & 0,14527 & 104,5 & \\
\hline 107,4 & 0,13687 & 107,2 & 0,12143 \\
\hline
\end{tabular}

Velocidade máxima de formação de metano. 


\begin{tabular}{|c|c|c|c|}
\hline \multicolumn{4}{|c|}{$30 \mathrm{mM}$} \\
\hline \multirow[b]{2}{*}{ Tempo ( } & \multirow[b]{2}{*}{$\begin{array}{c}\text { Velocidade de } \\
\text { Formação do } \\
\text { Metano } \\
\text { (mmol/L.h) }\end{array}$} & \multicolumn{2}{|c|}{ Reator (2) } \\
\hline & & Tempo ( & $\begin{array}{c}\text { Velocidade de } \\
\text { Formação do } \\
\text { Metano } \\
\text { (mmol/L.h) }\end{array}$ \\
\hline 0,0 & 5,11147E-4 & 0,0 & 0,00354 \\
\hline 2,7 & 5,70753E-4 & 2,7 & 85 \\
\hline 5,5 & $2 E-4$ & 5,5 & 52 \\
\hline 8,2 & $1 \mathrm{E}-4$ & 8,2 & 53 \\
\hline 11,0 & 07 & 11,0 & 21 \\
\hline 13,7 & 32 & 13,7 & 29 \\
\hline 16,5 & 0,00163 & 16,5 & 54 \\
\hline 19,2 & 01 & 19,2 & 0,01 \\
\hline 22,0 & 47 & 22,0 & 71 \\
\hline 24,7 & 05 & 24,7 & 71 \\
\hline 27,5 & 75 & 27,5 & 03 \\
\hline 30,2 & 62 & 30,2 & 74 \\
\hline 32,9 & 69 & 33,0 & 88 \\
\hline 35,7 & 0,00701 & 35,7 & 552 \\
\hline 38,4 & 863 & 38,5 & 0,02973 \\
\hline 41,2 & 61 & 41,2 & 59 \\
\hline 43,9 & 04 & 44,0 & 017 \\
\hline 46,7 & 01 & 46,7 & 656 \\
\hline 49,4 & 64 & 49,5 & 86 \\
\hline 52,2 & 06 & 52,2 & 14 \\
\hline 54,9 & 0,02943 & 54,9 & 47 \\
\hline 57,7 & 93 & 57,7 & 0,08194 \\
\hline 60,4 & 76 & 60,4 & 57 \\
\hline 63,1 & 15 & 63,2 & 38 \\
\hline 65,9 & 34 & 65,9 & 33 \\
\hline 68,6 & 56 & 68,7 & 34 \\
\hline 71,4 & 04 & 71,4 & 25 \\
\hline 74 & 0,11093 & 74 & 0,16783 \\
\hline 76 & 0,13134 & 76 , & 0,18476 \\
\hline 79 , & 0,1542 & 79 & 0,20163 \\
\hline 82,4 & 0,17926 & 82,4 & 0,21796 \\
\hline 85 & 0,20603 & 85,2 & 32 \\
\hline 87 & 0,23372 & 87 & 0,2468 \\
\hline 90 & 0,26122 & 90 & 0,25817 \\
\hline 93, & 0,28718 & 93, & 0,26681 \\
\hline 96 & 0,31005 & 96 , & 0,27231 \\
\hline 98,8 & 0,32826 & 98,9 & 0,2744 \\
\hline 101,6 & 0,34043 & 101,7 & 0,27297 \\
\hline 104,3 & 0,34557 & 104,4 & 0,26809 \\
\hline 107,1 & 0,34325 & 107,2 & 0,26 \\
\hline 109,8 & 0,33367 & 109,9 & 0,2491 \\
\hline 112,6 & 0,31762 & 112,6 & 0,23588 \\
\hline 115,3 & 0,29635 & 115,4 & 0,22089 \\
\hline 118,0 & 0,27139 & 118,1 & 0,20472 \\
\hline
\end{tabular}

Velocidade máxima de formação de metano. 


\begin{tabular}{|c|c|c|c|}
\hline \multicolumn{4}{|c|}{$50 \mathrm{mM}$} \\
\hline \multicolumn{2}{|c|}{ Reator (1) } & \multicolumn{2}{|c|}{ Reator (2) } \\
\hline Tempo (h) & $\begin{array}{c}\text { Velocidade de } \\
\text { Formação do } \\
\text { Metano } \\
\text { (mmol/L.h) }\end{array}$ & Tempo (h) & $\begin{array}{c}\text { Velocidade de } \\
\text { Formação do } \\
\text { Metano } \\
\text { (mmol/L.h) }\end{array}$ \\
\hline 0,0 & 0,00121 & 0,0 & $6,57911 \mathrm{E}-4$ \\
\hline 3,2 & 0,00133 & 3,2 & 7,25905E-4 \\
\hline 6,3 & 0,0016 & 6,3 & 8,75933E-4 \\
\hline 9,5 & 0,00192 & 9,5 & 0,00106 \\
\hline 12,7 & 0,00231 & 12,6 & 0,00128 \\
\hline 15,8 & 0,00277 & 15,8 & 0,00154 \\
\hline 19,0 & 0,00333 & 19,0 & 0,00186 \\
\hline 22,1 & 0,004 & 22,1 & 0,00224 \\
\hline 25,3 & 0,00481 & 25,3 & 0,0027 \\
\hline 28,5 & 0,00577 & 28,5 & 0,00326 \\
\hline 31,6 & 0,00693 & 31,6 & 0,00393 \\
\hline 34,8 & 0,00831 & 34,8 & 0,00474 \\
\hline 38,0 & 0,00997 & 37,9 & 0,00571 \\
\hline 41,1 & 0,01196 & 41,1 & 0,00689 \\
\hline 44,3 & 0,01434 & 44,3 & 0,0083 \\
\hline 47,4 & 0,01718 & 47,4 & 0,01 \\
\hline 50,6 & 0,02057 & 50,6 & 0,01204 \\
\hline 53,8 & 0,02461 & 53,8 & 0,0145 \\
\hline 56,9 & 0,02941 & 56,9 & 0,01744 \\
\hline 60,1 & 0,03511 & 60,1 & 0,02097 \\
\hline 63,3 & 0,04186 & 63,2 & 0,0252 \\
\hline 66,4 & 0,04982 & 66,4 & 0,03025 \\
\hline 69,6 & 0,05919 & 69,6 & 0,03628 \\
\hline 72,8 & 0,07015 & 72,7 & 0,04345 \\
\hline 75,9 & 0,08293 & 75,9 & 0,05196 \\
\hline 79,1 & 0,09771 & 79,0 & 0,06201 \\
\hline 82,2 & 0,1147 & 82,2 & 0,07385 \\
\hline 85,4 & 0,13405 & 85,4 & 0,08772 \\
\hline 88,6 & 0,15586 & 88,5 & 0,10387 \\
\hline 91,7 & 0,18014 & 91,7 & 0,12253 \\
\hline 94,9 & 0,20676 & 94,9 & 0,14393 \\
\hline 98,1 & 0,23544 & 98,0 & 0,1682 \\
\hline 101,2 & 0,26569 & 101,2 & 0,19539 \\
\hline 104,4 & 0,2968 & 104,3 & 0,22541 \\
\hline 107,5 & 0,32782 & 107,5 & 0,25797 \\
\hline 110,7 & 0,35759 & 110,7 & 0,29257 \\
\hline 113,9 & 0,38478 & 113,8 & 0,32839 \\
\hline 117,0 & 0,40804 & 117,0 & 0,36437 \\
\hline 120,2 & 0,42604 & 120,2 & 0,39914 \\
\hline 123,4 & 0,4377 & 123,3 & 0,43114 \\
\hline 126,5 & 0,44229 & 126,5 & 0,45872 \\
\hline 129,7 & 0,43949 & 129,6 & 0,48029 \\
\hline 132,9 & 0,42949 & 132,8 & 0,49449 \\
\hline 136,0 & 0,41294 & 136,0 & 0,50039 \\
\hline 139,2 & 0,39085 & 139,1 & 0,49758 \\
\hline 142,3 & 0,36448 & 142,3 & 0,48625 \\
\hline 145,5 & 0,33522 & 145,4 & 0,46717 \\
\hline 148,7 & 0,30439 & 148,6 & 0,44155 \\
\hline
\end{tabular}




\begin{tabular}{|c|c|c|c|}
\hline \multicolumn{4}{|c|}{$75 \mathrm{mM}$} \\
\hline \multicolumn{2}{|c|}{ Reator (1) } & \multicolumn{2}{|c|}{ Reator (2) } \\
\hline Tempo (h) & $\begin{array}{c}\text { Velocidade de } \\
\text { Formação do } \\
\text { Metano } \\
\text { (mmol/L.h) }\end{array}$ & Tempo (h) & $\begin{array}{c}\text { Velocidade de } \\
\text { Formação do } \\
\text { Metano } \\
\text { (mmol/L.h) }\end{array}$ \\
\hline 0,0 & $4,60383 \mathrm{E}-4$ & 0,0 & $3,11119 \mathrm{E}-4$ \\
\hline 3,3 & $5,0985 \mathrm{E}-4$ & 3,3 & $3,46782 \mathrm{E}-4$ \\
\hline 6,7 & $6,19409 \mathrm{E}-4$ & 6,7 & $4,26282 \mathrm{E}-4$ \\
\hline 10,0 & 7,52496E-4 & 10,0 & 5,23997E-4 \\
\hline 13,3 & $9,14157 \mathrm{E}-4$ & 13,3 & $6,44098 \mathrm{E}-4$ \\
\hline 16,7 & 0,00111 & 16,7 & 7,91704E-4 \\
\hline 20,0 & 0,00135 & 20,0 & $9,73105 \mathrm{E}-4$ \\
\hline 23,3 & 0,00164 & 23,3 & 0,0012 \\
\hline 26,7 & 0,00199 & 26,7 & 0,00147 \\
\hline 30,0 & 0,00242 & 30,0 & 0,00181 \\
\hline 33,3 & 0,00294 & 33,3 & 0,00222 \\
\hline 36,6 & 0,00357 & 36,6 & 0,00273 \\
\hline 40,0 & 0,00433 & 40,0 & 0,00335 \\
\hline 43,3 & 0,00526 & 43,3 & 0,00412 \\
\hline 46,6 & 0,00638 & 46,6 & 0,00506 \\
\hline 50,0 & 0,00774 & 50,0 & 0,00621 \\
\hline 53,3 & 0,0094 & 53,3 & 0,00762 \\
\hline 56,6 & 0,0114 & 56,6 & 0,00935 \\
\hline 60,0 & 0,01382 & 60,0 & 0,01148 \\
\hline 63,3 & 0,01675 & 63,3 & 0,01407 \\
\hline 66,6 & 0,0203 & 66,6 & 0,01724 \\
\hline 70,0 & 0,02457 & 70,0 & 0,02112 \\
\hline 73,3 & 0,02973 & 73,3 & 0,02584 \\
\hline 76,6 & 0,03594 & 76,6 & 0,03158 \\
\hline 80,0 & 0,04339 & 80,0 & 0,03855 \\
\hline 83,3 & 0,05233 & 83,3 & 0,04697 \\
\hline 86,6 & 0,063 & 86,6 & 0,05713 \\
\hline 89,9 & 0,07571 & 89,9 & 0,06933 \\
\hline 93,3 & 0,09077 & 93,3 & 0,08388 \\
\hline 96,6 & 0,10854 & 96,6 & 0,10114 \\
\hline 99,9 & 0,12935 & 99,9 & 0,12144 \\
\hline 103,3 & 0,15356 & 103,3 & 0,14509 \\
\hline 106,6 & 0,18146 & 106,6 & 0,17231 \\
\hline 109,9 & 0,21327 & 109,9 & 0,20319 \\
\hline 113,3 & 0,24906 & 113,3 & 0,2376 \\
\hline 116,6 & 0,28869 & 116,6 & 0,27515 \\
\hline 119,9 & 0,33175 & 119,9 & 0,31507 \\
\hline 123,3 & 0,37748 & 123,3 & 0,35615 \\
\hline 126,6 & 0,42471 & 126,6 & 0,39679 \\
\hline 129,9 & 0,47185 & 129,9 & 0,43498 \\
\hline 133,3 & 0,51693 & 133,3 & 0,46849 \\
\hline 136,6 & 0,5577 & 136,6 & 0,49509 \\
\hline 139,9 & 0,59185 & 139,9 & 0,51281 \\
\hline 143,2 & 0,61719 & 143,2 & 0,52025 \\
\hline 146,6 & 0,63199 & 146,6 & 0,5168 \\
\hline 149,9 & 0,63519 & 149,9 & 0,50276 \\
\hline 153,2 & 0,62655 & 153,2 & 0,47923 \\
\hline 156,6 & 0,6067 & 156,6 & 0,44802 \\
\hline 159,9 & 0,57705 & 159,9 & 0,41129 \\
\hline
\end{tabular}

Velocidade máxima de formação de metano. 


\begin{tabular}{|c|c|c|c|}
\hline \multicolumn{4}{|c|}{$90 \mathrm{mM}$} \\
\hline \multicolumn{2}{|c|}{ Reator (1) } & \multicolumn{2}{|c|}{ Reator (2) } \\
\hline 0,0 & $6,21518 \mathrm{E}-4$ & 0,0 & 0,00234 \\
\hline 3,2 & $6,8523 \mathrm{E}-4$ & 3,2 & 0,00255 \\
\hline 6,4 & $8,25704 \mathrm{E}-4$ & 6,4 & 0,00298 \\
\hline 9,6 & $9,94942 \mathrm{E}-4$ & 9,5 & 0,0035 \\
\hline 12,7 & 0,0012 & 12,7 & 0,0041 \\
\hline 15,9 & 0,00144 & 15,9 & 0,0048 \\
\hline 19,1 & 0,00174 & 19,1 & 0,00562 \\
\hline 22,3 & 0,0021 & 22,2 & 0,00659 \\
\hline 25,5 & 0,00253 & 25,4 & 0,00772 \\
\hline 28,7 & 0,00304 & 28,6 & 0,00904 \\
\hline 31,9 & 0,00366 & 31,8 & 0,01058 \\
\hline 35,0 & 0,00441 & 35,0 & 0,01238 \\
\hline 38,2 & 0,00531 & 38,1 & 0,01448 \\
\hline 41,4 & 0,00639 & 41,3 & 0,01693 \\
\hline 44,6 & 0,00769 & 44,5 & 0,01979 \\
\hline 47,8 & 0,00926 & 47,7 & 0,02312 \\
\hline 51,0 & 0,01113 & 50,9 & 0,02699 \\
\hline 54,1 & 0,01338 & 54,0 & 0,03149 \\
\hline 57,3 & 0,01607 & 57,2 & 0,0367 \\
\hline 60,5 & 0,0193 & 60,4 & 0,04273 \\
\hline 63,7 & 0,02316 & 63,6 & 0,04969 \\
\hline 66,9 & 0,02776 & 66,7 & 0,0577 \\
\hline 70,1 & 0,03323 & 69,9 & 0,0669 \\
\hline 73,3 & 0,03974 & 73,1 & 0,07742 \\
\hline 76,4 & 0,04745 & 76,3 & 0,08939 \\
\hline 79,6 & 0,05654 & 79,5 & 0,10296 \\
\hline 82,8 & 0,06723 & 82,6 & 0,11825 \\
\hline 86,0 & 0,07973 & 85,8 & 0,13535 \\
\hline 89,2 & 0,09425 & 89,0 & 0,15434 \\
\hline 92,4 & 0,11101 & 92,2 & 0,17524 \\
\hline 95,6 & 0,13019 & 95,3 & 0,19799 \\
\hline 98,7 & 0,15189 & 98,5 & 0,22245 \\
\hline 101,9 & 0,17616 & 101,7 & 0,24839 \\
\hline 105,1 & 0,20291 & 104,9 & 0,27543 \\
\hline 108,3 & 0,23187 & 108,1 & 0,30307 \\
\hline 111,5 & 0,26257 & 111,2 & 0,33068 \\
\hline 114,7 & 0,29432 & 114,4 & 0,3575 \\
\hline 117,8 & 0,32615 & 117,6 & 0,38266 \\
\hline 121,0 & 0,35686 & 120,8 & 0,40525 \\
\hline 124,2 & 0,3851 & 124,0 & 0,42436 \\
\hline 127,4 & 0,40942 & 127,1 & 0,43917 \\
\hline 130,6 & 0,42844 & 130,3 & 0,44898 \\
\hline 133,8 & 0,44097 & 133,5 & 0,45333 \\
\hline 137,0 & 0,4462 & 136,7 & 0,45199 \\
\hline 140,1 & 0,44378 & 139,8 & 0,44504 \\
\hline 143,3 & 0,43386 & 143,0 & 0,43281 \\
\hline 146,5 & 0,41712 & 146,2 & 0,41588 \\
\hline 149,7 & 0,3946 & 149,4 & 0,39503 \\
\hline 152,9 & 0,36763 & 152,6 & 0,37111 \\
\hline 156,1 & 0,33766 & 155,7 & 0,34507 \\
\hline 159,3 & 0,3061 & 158,9 & 0,31778 \\
\hline
\end{tabular}

Velocidade máxima de formação de metano. 
ANEXO 1 - Curva de Calibração do Metano

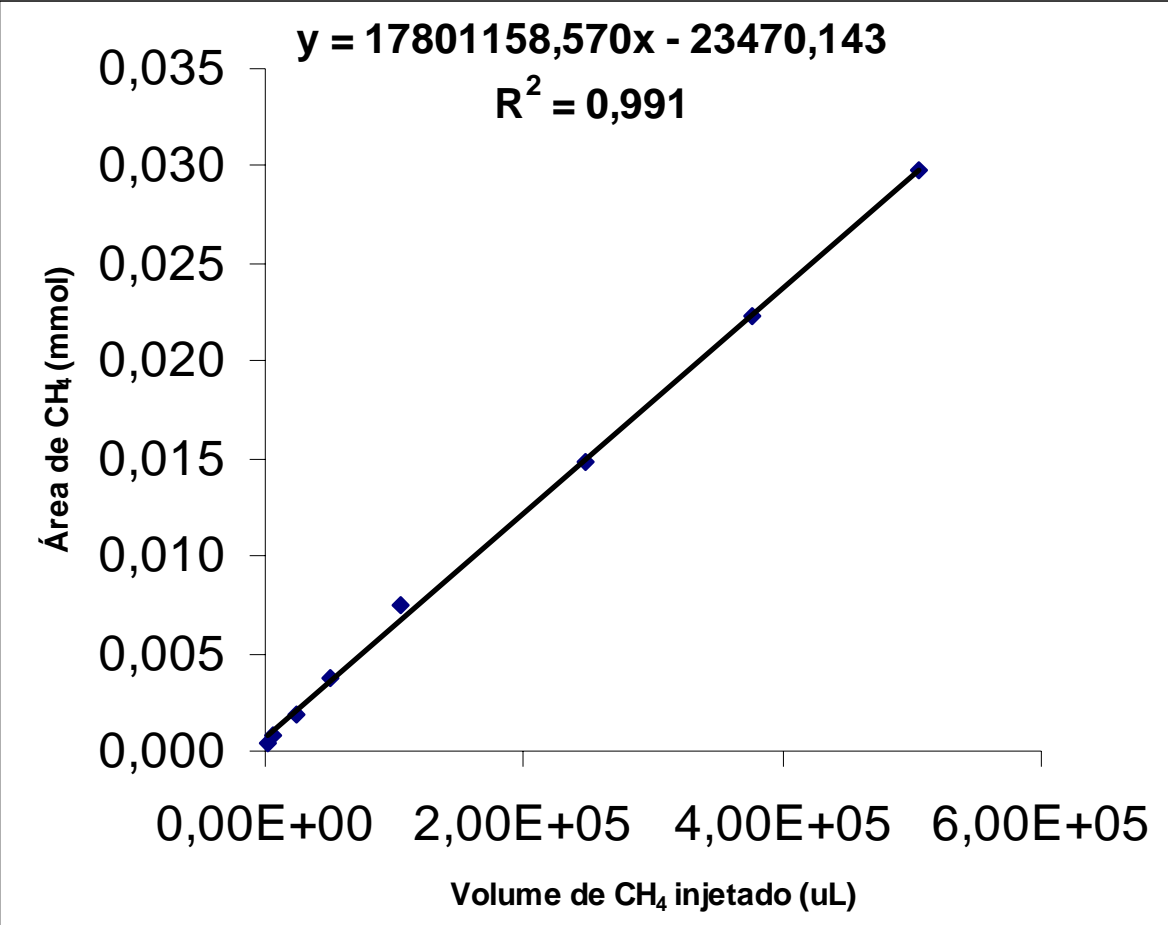

